\title{
Katalizátorok felületének jellemzése röntgen-fotoelektron spektroszkópiával
}

\author{
Doktori $(\mathrm{PhD})$ értekezés
}

\section{Pótári Gábor}

Témavezető: Dr. Erdőhelyi András

Kémia Doktori Iskola

SZTE TTIK

Fizikai Kémiai és Anyagtudományi Tanszék

Szeged, 2014 


\section{Tartalomjegyzék}

1. Bevezetés 1

2. Célkitúzés 4

3. Irodalmi áttekintés 5

3.1. $\mathrm{TiO}_{2}$ felület fizikai és kémiai tulajdonságai . . . . . . . . . . . . . 5

3.2. $\mathrm{TiO}_{2}$ nanocsövek, nanoszálak fizikai és kémiai jellemzése . . . . . . . . . . 9

3.3. $\mathrm{TiO}_{2}$ felületek vizsgálata XPS módszerrel . . . . . . . . . . . . . . . . . . 12

4. Kísérleti rész 16

4.1. XPS, LEIS módszerek rövid áttekintése . . . . . . . . . . . . . . . 16

4.2. XP spektrumok fốbb jellemvonása . . . . . . . . . . . . . . . . 20

4.3. XP spektrumok kiértékelésének lépései . . . . . . . . . . . . . 22

4.4. XPS és LEIS spektrumok felvétele során alkalmazott mérési paraméterek 24

5. Eredmények 26

5.1. $\mathrm{TiO}_{2}$ nanoszálak és nanocsövek termikus kezelése és XPS vizsgálata . . . . 26

5.2. $\mathrm{TiO}_{2}$ nanoszálak és nanocsövek módosítása fémekkel . . . . . . . . . . . . 30

5.2.1. Ródiummal módosított $\mathrm{TiO}_{2}$ nanoszálak és nanocsövek XPS vizsgálata 30

5.2.2. Arannyal módosított $\mathrm{TiO}_{2}$ nanoszálak és nanocsövek XPS vizsgálata 34

5.2.3. Arany-ródium kétfémes rendszerek XPS és LEIS vizsgálata . . . . 36

5.2.4. Kobalttal módosított $\mathrm{TiO}_{2}$ nanoszálak és nanocsövek XPS vizsgálata 42

5.3. Katalizátorok kémiai reakciók hatására bekövetkező felületmódosulásának vizsgálata . . . . . . . . . . . . . . . . . . . . 46

5.3.1. Száraz reformálás $\mathrm{Rh} / \mathrm{Al}_{2} \mathrm{O}_{3}, \mathrm{Rh} / 10 \% \mathrm{TiO}_{2}-\mathrm{Al}_{2} \mathrm{O}_{3}$ és $\mathrm{Rh} / 10 \% \mathrm{~V}_{2} \mathrm{O}_{5^{-}}$$\mathrm{Al}_{2} \mathrm{O}_{3}$ katalizátorokon . . . . . . . . . . . . . 46

5.3.2. Dimetil karbonát szintézise rézzel adalékolt szén nanocsövön . . 49

6. Összefoglalás $\quad 54$ 
7. Summary

Irodalomjegyzék

Köszönetnyilvánítás

70 


\section{1. fejezet}

\section{Bevezetés}

Minden szilárd anyag a felületén keresztül érintkezik környezetével. A felületek fizikai és kémiai összetétele meghatározza ennek a kölcsönhatásnak a jellegét. Az említett kémiai összetétel többek között a szilárd anyagok katalitikus aktivitását, adszorpciós tulajdonságát, nedvesedését, kontakt potenciálját befolyásolja. Annak ellenére, hogy a felület döntő szerepet játszik a szilárd testek előbb említett jellemzőinek kialakításában, általában a teljes térfogatához képest csak kevés atom található ebben a tartományban. Annak érdekében, hogy errôl a szúk régióról információt nyerhessünk, megfelelően érzékeny felületvizsgálati technikákat kell igénybe venni.

Bár az Auger elektron spektroszkópia (AES) és a röntgen-fotoelektron spektroszkópia (XPS) kialakulása különböző történeti utat járt be, ennek ellenére mindkettő az elektronspektroszkópiák családjába tartozik, hasonló energia tartományról nyújtanak információt és így nagyon sok közös vonással rendelkeznek. Az évek során a két technika egyre inkább közeledett egymáshoz a kivitelezésük nagyfokú hasonlóságának köszönhetően. A modern félgömb analizátorok kifejlesztésével a két spektroszkópia már egy készülékbe integrálva is megvalósíthatóvá vált, melyben egy röntgenágyú és egy elektronágyú biztosította a kétféle mérés elvégzésének lehetőségét.

Az XPS története tekint vissza nagyobb múltra, melynek a kezdete az 1887-es évre tehetô, mikor is Heinrich Herz felfedezte, hogy megfelelően nagy frekvenciájú elektromágneses sugárzás elektronemissziót képes kiváltani szilárd anyagokból (fotoelektromos hatás). A jelenséget a későbbiekben Hallwachs, Wolf és Lénárd is vizsgálták, a legfontosabb eredmény Lénárd nevéhez fűződik, aki először írta le a kilépési munka fogalmának bevezetésével a fény indukálta elektron kilépést fémek felületéből. A röntgensugárzás felfedezését Wilhelm Conrad Röntgen nevéhez kötik (1895), amiért fizikai Nobel-díjjal jutalmazták munkásságát 1901-ben. Miután 1905-ben Einstein megadta a kvantumelméleti értelmezését a fényelektromos jelenségnek, világossá vált, hogy a fotoelektron energiája információt hordoz a fém anyagi minőségére vonatkozóan, melyből távozott. Az elsô XP spektrum Innes nevéhez 
köthető, aki 1907-ben egy röntgencső segítségével kiváltott fotoelektron emisszió sebességeloszlását határozta meg. Rutherford és munkatársai 1914-ben felismerték, hogy a fotoelektron kinetikus energiája a röntgensugárzás és az elektron kötési energiájának különbségével egyenlő. Az első XPS témájú tudományos közlemény Mang-Fuh Hu, a Harvad Egyetem kutatójához köthetô, aki röntgensugárzás hatására, fémekből kiváltott fotoelektronok maximális emissziós sebességének meghatározásának lehetőségét vizsgálta. Az ezt követő néhány évtizedben a röntgensugárzás indukálta fotoelektron spektroszkópia fejlődése, kivitelezésének bonyolultsága miatt, kissé megtorpant a röntgen spektroszkópiához képest. Az XPS fejlődésében Harold Roper Robinson és munkatársainak eredménye tekinthető a következő mérföldkőnek, akik az 1930-as években elsőként figyelték meg a kémiai kötések különbözőségéből eredő vonaleltolódásokat, amire az analitikai alkalmazhatóság szempontjából igen fontos eredményként kell tekintenünk. Az elektron spektrométerek pontosságának fejlődése az 1950-es években az első, nagyfelbontású XP spektrum rögzítését már lehetővé tette, melyben Ralph Steinhardt-nak és Earl Serfass-nak a Lehigh Egyetem, illetve Kai Siegbahn-nak az uppsala-i egyetem kutatóinak elévülhetetlen érdemei voltak. Az ezt követő években Siegbahn és munkatársai behatóan tanulmányozták, hogy a kémiai kötések miként képesek befolyásolni a törzselektronok kötési energiáját. Az ESCA (electron spectroscopy for chemical analysis) elnevezés is Siegbahn-tól ered, aki az Auger- és a fotoelektronok által szolgáltatott információt egységesen, egymást kiegészítően kezelte. Munkásságáért 1981-ben fizikai Nobel-díjjal jutalmazták. A XPS készülékek az 1960-as években kezdtek elterjedni, a kémikusok között gyorsan, nagy népszerúségre szert téve. Az 1970-es években gondot okozott, hogy az elsố generációs XPS készülékek, az AES-hoz képest rosszabb jel/zaj viszonnyal és alacsony röntgensugárzás intenzitással rendelkeztek. Ezért viszonylag lassú és időigényes módszer volt. Ezen hátrányok leküzdésében a többcsatornás detektálási lehetôséggel ellátott digitális készülékek megjelenése és az analizátorok transzmissziójának javítása jelentette a megoldást. Ez vezetett oda, hogy 1985-tôl egyre inkább maga mögé tudta utasítani az XPS az AES-t, ami a megjelent publikációk mennyiségével mérhetô le.

Az AES történetét a francia fizikus, Pierre Victor Auger kutatásaival kezdhetjük, aki először írta le a róla elnevezett elektronemisszió jelenségét. 1929-ben ô is a röntgensugárzás által kiváltott elektronkibocsájtást elemezte Wilson-féle ködkamra segítségével. Ekkor figyelte meg, hogy a fotoelektronokon kívül vannak olyan elektronok is, melyek kinetikus energiája független a röntgensugárzás energiájától, majd 1926-ban megadta a jelenség pontos mechanizmusát is. A felfedezést követôen, a röntgensugárzási spektroszkópiák fejlesztése során, sokáig nemkívánatos velejáróként könyvelték el az Auger sugárzást. 1953-ban Lander vetette fel annak lehetôségét, hogy a karakterisztikus Auger-elektron csúcsokat is fel lehet használni elemanalízis céljából. Azonban ekkor még túlságosan kis intenzitású csúcsokat szolgáltatott a szekunder elektronemisszió, ami gátat szabott az analitikai felhasz- 
nálhatóságának. A nehézségeket Harris-nek sikerült kiküszöbölnie 1965-ben végzett úttörő munkásságával. Ő úgy oldatta meg a problémát, hogy a rögzített energia eloszlási görbék deriváltját képezte. Ezzel a relatív nagy abszolút értékú, de közel állandó meredekséggel változó háttérelektronok hozzájárulását sikerült elnyomni, míg a relatív kis abszolút értékú, de sokkal gyorsabban változó Auger-elektronok jeleit sikerült felerősíteni a transzformált spektrumokon. A következő, fontos állomás az AES továbbfejlesztésében Weber és Peria felismerése volt 1967-ben, akik észrevették, hogy a LEED eljárásban elterjedten használt optikai megoldások az Auger-spektroszkópiába is átültethetôk. Ez a megoldás áttörést hozott az AES felület vizsgálati módszerként való felhasználásában és egyre több laboratóriumban megjelentek a kereskedelmi forgalomban kapható készülékek. Két évvel később Palmberg, Bohn és Tracy bevezette a cilindrikus deflektor analizátort, mely tovább növelte a detektálás határának érzékenységét. A következő évek, évtizedek a lencserendszer és az elektronoptika rohamos fejlődését hozták. A gerjesztő elektronnyaláb fókuszálásáért felelős lencserendszer tökéletesítése egyre finomabb térbeli felbontást tett lehetővé, ami a 70-es években a pásztázó Auger mikroszkópia (SAM) megszületéséhez vezetett. 


\section{2. fejezet}

\section{Célkitứzés}

A kutatócsoport, melynek három éven keresztül tagja voltam, heterogén katalitikus reakciók tanulmányozásával foglalkozik, ahol az összetett munka rám háruló része a szilárd minták röntgen-fotoelektron spektroszkópiai jellemzése volt. Az esetek döntő hányadában a kapott minták felületi összetételének meghatározása, a reakciók hatására bekövetkező változások feltérképezése állt. Mivel az általam használt XPS készülék rendelkezik egy nagynyomású kezelőkamrával, ezért a kinetikai mérésekkel közel azonos paraméterek mellett tudtam ugyanazt a reakciót lejátszatni az aktuálisan vizsgált katalizátorokon. Érdeklődésünk központi témáját a titanát nanocsövek és nanoszálak kutatása képezte. Egyfelől arra kerestük a választ, hogy miként viselkednek ezek a nanostruktúrák felfútés hatására, meddig képesek megốrizni stabilitásukat. Ezen kívül kíváncsiak voltunk arra is, hogy a felületükre felvitt fémek (arany, ródium), vagy kobalt-karbonil milyen formában vannak jelen, milyen struktúra jön létre a kétfémes minták esetében, illetve a fém és a hordozó között kimutatható-e valamilyen kölcsönhatás. Célkitûzéseink között szerepelt a $\mathrm{CH}_{4}+\mathrm{CO}_{2}$ reakcióban az adalékolt $\mathrm{Al}_{2} \mathrm{O}_{3}$-ra felvitt $\mathrm{Rh}$ katalizátorok aktivitása között észlelt különbségek értelmezése és magyarázata. További kutatási témánk volt annak tisztázása, hogy többfalú szén nanocsőre felvitt réz oxidációs állapota változik-e, ha $\mathrm{CH}_{3} \mathrm{OH}+\mathrm{CO}+\mathrm{O}_{2}$ reakció játszódik le rajta, és ez összefüggésbe hozható-e a kutatócsoportunk által kimutatott katalitikus aktivitás változással. 


\section{3. fejezet}

\section{Irodalmi áttekintés}

\section{1. $\quad \mathrm{TiO}_{2}$ felület fizikai és kémiai tulajdonságai}

Az anyagtudományban a katalizátorok múködésének szempontjából a fém és az oxidhordozó közötti kölcsönhatás kitüntetett jelentőséggel bír. Ha a fémrészecskék mérete a nanométeres tartományba esik, olyan új fizikai és kémiai tulajdonságok jelennek meg, melyekkel a tömbfázisbeli anyag nem rendelkezik. Ezzel párhuzamosan a fém és a hordozó közötti kölcsönhatás egyre fontosabb szerepet játszik a heterogén katalitikus folyamatok értelmezésében [1-3]. Általában igaz, hogy a katalizátorok aktivitása és szelektivitása összefüggésben van a részecskemérettel, a felületi fématomok és a tömbfázisbeliek arányával [4]. Napjainkban is intenzív kutatások folynak a $\mathrm{TiO}_{2}$ hordozós katalizátorok pontosabb megismerésének érdekében, mivel könnyen redukálhatóak és erős fém-hordozó kölcsönhatás (SMSI) kialakítására képesek. A jelenséget Tauster és munkatársai írták le először, mikor magas hőmérsékleten redukált titán-dioxid hordozóra felvitt nemesfémek $\mathrm{H}_{2}$ és $\mathrm{CO}$ kemiszorpciós kapacitásának csökkenését tapasztalták, miközben katalitikus aktivitásuk lényegesen kisebb mértékben csökkent [5]. Az erôs fém-hordozó kölcsönhatás kialakulásakor az oxidhordozó részlegesen redukált részecskéi vékony réteget képeznek a fém felületén, ezáltal blokkolva annak katalitikus aktivitását [6]. Ezen geometriai tényezőn túl nagyon fontos szerepet játszik a katalizátorok viselkedésében az elektromos tényező is, mely a fém elektronrendszerének perturbációjából származik a hordozóval való kölcsönhatás következtében létrejövő töltésátviteli folyamatok révén. A hordozó képes polarizálni a vele fizikai kontaktusban álló katalizátor részecskék vegyértékelektron rendszerét, jelentősen módosítva annak elektromos tulajdonságait (carrier effect).

Berkó és munkatársai háromféle $\mathrm{TiO}_{2}(110)$ felületen vizsgálták a ródium enkapszulációs folyamatát [7]. Jól rendezett $\mathrm{TiO}_{2}(110)$ felületen nem tapasztaltak dekorációs effektust, még abban az esetben sem, mikor gyenge $\mathrm{Ar}^{+}$-ionos bombázásnak kitett titanátokat tanulmányoztak. Azonban ha erôs $\mathrm{Ar}^{+}$-ionos kezelést alkalmaztak, a ródium klaszterek el- 
fedését figyelték meg. Ez azzal magyarázható, hogy az intenzív ionbombázás elektronban gazdag felszínközeli réteget hozott létre, ami hozzájárult az enkapszulációs mechanizmusok megjelenéséhez. Más kutatócsoportok is hasonló megállapításra jutottak más nemesfémeket (Pt, Pd) vizsgálva: a magas hômérsékleten végrehajtott redukciót követôen kimutatható az SMSI, míg sztöchiometrikus kristályokon nem figyelhető meg [8-13]. Az erôs fém-hordozó kölcsönhatás kialakulásának szempontjából további fontos tényező a fém felületi energiája ( $\lambda$ ). Kimutatták, hogy ha $\lambda>2 \mathrm{~J} / \mathrm{m}^{2}$, az enkapszuláció nagyobb valószínúséggel következik be $[14,15]$. Így a fémrészecskék minimalizálni tudják felületi energiájukat azáltal, hogy a hordozóval való befedés következtében kisebb energiájú felület jön létre.

A sztöchiometrikus összetételû anatáz titán-dioxidban a vezetési és a vegyérték sáv közti távolság 3,2 eV nagyságú [16,17]. A vezetési sáv létrejöttében elsősorban a titán karakter (Ti 3d) dominál, míg a vegyértéksáv döntően az oxigén atomok (O 2p) által befolyásolt. A vegyértéksáv kísérleti és elméleti tanulmányozása bizonyította, hogy a sávban az O 2p és Ti 3d pályák között hibridizáció jön létre [18].

A titán-dioxid felszínén jellemzően két titán- és két oxigén pozíciót lehet megkülönböztetni. A hatfogású Ti atom a koordinációs szférájában elhelyezkedô oxigének által definiált oktaéder közepén foglal helyet. Az oktaéder felület irányába elhelyezkedő kétfogású oxigénjének eltávolításával az ötfogású titán adódik. Ezen kívül a felületben háromfogású oxigén atomok is helyet foglalnak, melyek három titánhoz kapcsolódnak. Több tanulmány is bizonyítja, hogy az a $\mathrm{TiO}_{2}$ felület stabil, melyben a kisebb koordinációs számú Ti és O atomok egyaránt jelen vannak [27].

A titán-dioxid hordozót napjainkban is széles körben vizsgálják, melyben nagy szerepe van Haruta-nak, aki 5-10 nm átmérőjű aranyklasztereket tartalmazó mintákon tanulmányozta a CO oxidációját alacsony hőmérsékleten $(200 \mathrm{~K})$ és megnövekedett aktivitást tapasztalt [19, 20]. Tanulmányában kitüntetett szerepet tulajdonít a fémrészecskék peremrégiójának, amit a reakció lejátszódásának tényleges helyeként jelöl meg.

Az arany adszorpciójának vizsgálata $\mathrm{TiO}_{2}(110)$ felületen szintén gazdag irodalommal büszkélkedhet. Elméleti számolások azt mutatják, hogy az arany az ötös koordinációjú Ti és a kétfogású $\mathrm{O}$ atomokhoz kapcsolódnak, melyek közel azonos kötési energiával rendelkeznek [21-23]. Ezt gyakorlati eredmények is alátámasztják, ugyanis STM felvételek segítségével bizonyították, hogy a nanoméretú aranyrészecskék az ötfogású titán atomok alkotta sorokon adszorbeálódnak [24]. Tong és munkatársai $\mathrm{TiO}_{2}(110)$ felületre felvitt 1-8 atomból álló Au klasztereket tanulmányoztak STM-mel és az előbbi megállapítással azonos következtetésre jutottak [25].

A titán-dioxid felületén viszonylag könnyen lehet oxigén hibahelyeket létrehozni, míg az intersticiális pozícióban található titán atomok kisebb számban vannak jelen. A Schottkyféle szimbólumok felhasználásával az oxigén hibahelyek kialakulására a következő egyenlet 
írható fel:

$$
\mathrm{TiO}_{2}=|O|^{\cdot \cdot}+2 e^{\prime}+1 / 2 \mathrm{O}_{2}^{(g)},
$$

míg az intersticiális titán képződésére:

$$
\mathrm{TiO}_{2}=\mathrm{Ti} \cdot+e^{\prime}+\mathrm{O}_{2}^{(g)}
$$

ahol $|O|^{* *}$ az oxigénanion vakanciát, $e^{\prime}$ a szabad elektront, $T i$. az intersticiális pozícióban helyet foglaló titánt jelöli [26]. Az oxigénvakanciák képződésekor, ami végbemehet a felületen és a tömbfázisban is, két elektron marad vissza, melyek a környező Ti atomok betöltetlen $3 \mathrm{~d}$ pályáin foglalnak helyet, ezáltal $\mathrm{Ti}^{3+}$ redukált ionok létrejöttét eredményezik [28]. A 3d pályák részleges betöltése új elekronállapotok kialakulásához vezet a tiltott sáv régiójában, melyre Diebold munkásságának köszönhetően kísérleti és elméleti bizonyítékok is rendelkezésünkre állnak [27]. Az új állapot a Fermi-szint alatt körülbelül 0,8 eV-tal helyezkedik el és jelenléte a nemsztöchiometrikus összetételú felület azonosítására nyújt lehetőséget.

A felületi oxigénvakanciák fontos szerepet játszanak a katalitikus viselkedés szempontjából is, mivel a hordozó és fém közötti kölcsönhatást erôsen befolyásolják. Kialakításuk többféleképpen történhet, ultranagy vákuumban végrehajtott fútéssel, argonion bombázással, UV besugárzás révén, melyek megfelelő alkalmazásával szabályozni lehet az oxigénvakanciák felületi koncentrációját [29]. STM képeken a kétfogású oxigén atomok által alkotott sötétebb árnyalatú sorokon centrált világos foltokként jelennek meg, ami bizonyítja, hogy nem a három titán atomhoz kapcsolódó oxigének hiányáról van szó [30]. A hibahelyek könnyen reakcióba lépnek vízzel, mely felületi hidroxil csoportok kialakulását eredményezi [31-33].

A Pauling-féle elektronegativitás $\left(\mathrm{X}_{M}\right)$ figyelembe vétele segítségünkre lehet a fémek $\mathrm{TiO}_{2}(110)$ felületen való adszorpciójának értelmezésekor. Abban az esetben, ha $\mathrm{X}_{M}<1,9$ a fémek a felületi oxigénekhez kapcsolódnak, erős fém-oxigén kötést létrehozva, míg a lépcsốkkel és oxigénvakanciákkal nem lépnek kölcsönhatásba. Ez a nagy adszorpciós hôvel és a kismértékú diffúzióval magyarázható [34-36]. Nemesfémek esetén $\left(\mathrm{X}_{M}>1,9\right)$ a felület inhomogenitásai nagyobb szerepet játszanak az adszorpció során. Több esetben megfigyelték, hogy a lépcsốk élei preferált adszorpciós helyekként funkcionálnak sztöchiometrikus felületen [37-42]. Mivel gyenge kölcsönhatások jellemzik a folyamatot, ezért az adszorptívum nagyobb mobilitása révén az élekhez diffundál, ahol végül potenciális energiagödörbe kerülve feldúsul [43]. Az $\mathrm{X}_{M}<1,9$ esettel ellentétben itt a fématomok és az oxigénvakanciák között erôs kapcsolat jön létre. Tong és munkatársai Ag klaszterek képződésekor figyelték meg, hogy a részecskenövekedés az oxigén hibahelyeken indul meg, köszönhetôen annak, hogy az így kialakuló kötés $0,5 \mathrm{eV}$ energiával nagyobb, mint a felület más pontjain létrejövők [44]. 130 K hőmérsékleten, nagyfelbontású STM-mel végzett kísérletek hasonló eredményre vezettek Au esetén is. Sztöchiometrikus $\mathrm{TiO}_{2}$ felületen a kialakuló kötés polarizációs 
hatások eredménye, míg a hibahelyekkel rendelkező mintákon kovalens kötés kialakulásával kell számolni, ahol negatív töltésú $\mathrm{Au}^{-}$találhatók [45,46]. Az arany klaszterek és a felület között létrejövő kötés erősségét a felületi hidroxil csoportok száma is nagyban befolyásolja, ugyanis a hidroxil csoportokban gazdag $\mathrm{TiO}_{2}(110)$ felület lényegesen gyengébb kötések kialakulását eredményezi az oxigénvakanciákat tartalmazókkal összehasonlítva [47,48].

A felületen adszorbeálódott fém és a hordozó között kialakuló kölcsönhatások további értelmezéséhez termodinamikai és kinetikai megfontolások segíthetnek közelebb jutni. A termodinamikai potenciálfüggvények lehetőséget biztosítanak annak eldöntésére, hogy egy reakció spontán lejátszódása bekövetkezhet-e, avagy sem. $\mathrm{A} \mathrm{TiO}_{2}$ és a fém között redoxreakciót feltételezve, a következő egyenlet írható fel:

$$
\mathrm{M}+\mathrm{TiO}_{2}=\mathrm{MO}_{x}+\mathrm{TiO}_{2-x} .
$$

A reakció értelmezéséhez induljunk ki a reakció szabadentalpia definíciójából: $\triangle G_{R}=$ $\triangle H_{R}-T \triangle S_{R}$. Mivel szilárd fázisú reakcióról van szó, ezért a folyamatot kísérô entrópiaváltozás nagyságát elhanyagolhatónak vehetjük. Így az entalpiaváltozás nagysága és előjele fogja döntően megszabni a reakció termodinamikáját [49]. Diebold arra az általános következtesésre jutott, hogy a fémoxidok képződése abban az esetben kedvezményezett, ha a reakciót kísérō entalpiaváltozás 1 mol O atomra vonatkoztatott értéke kisebb, mint -250kJ. Ez az egyszerú megállapítás több fém/ $\mathrm{TiO}_{2}$ felület esetén is igaznak bizonyult [27]. Kinetikai megfontolások alatt felületi anyagtranszport folyamatokat kell érteni. $\mathrm{TiO}_{2}$ esetén ebbe a folyamatba tartozik a $\mathrm{Ti}^{n+}(\mathrm{n} \leq 4)$ ionok és a $\mathrm{V}_{O}^{x+}(\mathrm{x}=1$ vagy 2$)$ oxigénvakanciák elmozdulása. A felületi reakciók természetétől függően különböző defekthelyek diffúziójára kell számítani. Ha példaként a fémek oxidációját tekintjük $\mathrm{TiO}_{2}$ felületén, akkor az oxigén anionok $\left(\mathrm{O}^{2-}\right)$ kifele irányuló diffúziója a döntő tényezô, ami ezzel egyidejûleg az oxigénvakanciák $\left(\mathrm{V}_{O}^{x+}\right)$ befele irányuló vándorlását vonja maga után a felületközeli régiókban. $\mathrm{Az}$ $\mathrm{O}^{2-}$ ionok diffúzióját $\mathrm{Al} / \mathrm{TiO}_{2}$ [50], $\mathrm{V} / \mathrm{TiO}_{2}$ [51], $\mathrm{Cr} / \mathrm{TiO}_{2}$ [52] és $\mathrm{Mo} / \mathrm{TiO}_{2}$ [53] rendszerekben is megfigyelték. A Ti ${ }^{n+}$ kationok - a tömbfázis kristályrácsának intersticiális pozícióiból - kifele irányuló diffúziója az erôs fém-hordozó kölcsönhatás kialakulásában gátló tényezőnek bizonyult [14]. Több tanulmányban is megállapították, hogy a hőmérséklet növelése (500-800 K) a Ti ${ }^{n+}$ ionok megnövekedett diffúzivitását vonja maga után és ezen ionok migrációja döntően befolyásolja az oxigén indukálta felületátrendeződéseket és a tömbfázis által befolyásolt $\mathrm{TiO}_{2}$ felület visszaoxidálódást [12,54-58]. Az alacsonyabb hőmérséklet tartományban a fém- $\mathrm{TiO}_{2}$ rendszerek csökkent reaktivitásával kell számolni [59-62]

Valamely fém és a $\mathrm{TiO}_{2}$ szilárd hordozó között kialakuló kémiai kapcsolat értelmezésében a két partner elektronszerkezetének viszonyát, a Fermi-szintek $\left(\mathrm{E}_{F}\right)$ helyzetét is figyelembe kell venni. Titán-dioxid kristályok felületén extranívók jöhetnek létre, idegen anyagok, kristályhibák következtében, melyek pozíciója a tiltott sávba is eshet. A hordozó és a 
rajta helyet foglaló fémklaszter között beálló termikus egyensúlyban a - kiindulási állapotban különböző - Fermi-nívók egybeesnek a két rendszer között lejátszódó elektronáramlás következtében. $\mathrm{Ha} \mathrm{E}_{F}\left(\right.$ fém) $>\mathrm{E}_{F}\left(\mathrm{TiO}_{2}\right)$, a két rendszer érintkezésekor elektronok mennek át a fémről, betöltve az oxid alacsonyabb energiájú nívóit. A töltésvándorlás miatt a félvezető felületi rétegében olyan potenciálgát jön létre, ami megfelelően nagy értéket elérve akadályozza a töltések további migrációját. Ha szemléltetni kívánjuk a kialakuló energiasávokat, akkor a félvezető tömbfázisából indulva, az érintkezési felület irányába egy lefele görbülő sémát kapunk. Szemléletesen úgy is fogalmazhatunk, hogy a kialakuló potenciálgát akadályozza az elektronok további áramlását. Ez az állapot az $\mathrm{O}^{2-}$ ionok pozitív töltésú felület irányába mutató diffúziójának, így a fém oxidációjának kedvez. Ha az $\mathrm{E}_{F}($ fém) < $\mathrm{E}_{F}\left(\mathrm{TiO}_{2}\right)$ esetet vizsgáljuk, akkor az előzőhöz képest ellentétes viszonyok alakulnak ki, mivel az elektronáramlás most a hordozóból a fém irányába mutat, felfele hajló energiasávokat eredményezve. A félvezető donornívóiról a vezetési sávban kialakuló potenciálgát miatt nem jutnak át elektronok a fémbe, miután elértük a termikus egyensúlyt. Most a $\mathrm{Ti}^{n+}$ kationok diffúziója játszódik le a felszínre és az enkapszuláció kedvezményezetté válik.

Különbözó vegyértékú ionokkal dópolva a $\mathrm{TiO}_{2}$-ot eltérő vezetôképességbeli változásokat tapasztalhatunk. Magasabb vegyértékú ionok, pl. $\mathrm{Ta}(\mathrm{V}), \mathrm{Nb}(\mathrm{V}), \mathrm{W}(\mathrm{VI})$ rácsba épülése vezetésnövekedést okoz. $\mathrm{A} \mathrm{WO}_{3}$ esetében az alábbi egyenletet írhatjuk fel:

$$
W O_{3}=W|T i| \cdots+2 e^{\prime}+\mathrm{TiO}_{2}+1 / 2 \mathrm{O}_{2}^{(g)},
$$

ahol $W|T i|$ • jelöli a rácspontot, ahol a Ti(IV) helyett W(VI) foglal helyet. Látható, hogy a folyamatot elektron felszabadulás kíséri, ami magyarázza a vezetőképesség növekedését. Ezzel szemben, ha a Ti(IV)-nél kisebb töltésú kationok, pl. Ni(II), Al(III) beépülése következik be, akkor azok csökkenteni fogják a kristályrács szabad elektronjainak számát [26].

\section{2. $\mathrm{TiO}_{2}$ nanocsövek, nanoszálak fizikai és kémiai jellem- zése}

Iijima 1991-ben megjelent cikke, melyben a szén nanocsövek szintézisének módszerét ismertette, jelentôs eredménynek tekinthetô az egydimenziós nanostruktúrált anyagok kutatásában [63]. Az érdeklődés az elmúlt évtizedben tovább növekedett, mivel különböző félvezetô oxidokból $\left(\mathrm{ZnO}, \mathrm{SnO}_{2}, \mathrm{In}_{2} \mathrm{O}_{3}, \mathrm{Ga}_{2} \mathrm{O}_{3}, \mathrm{~V}_{2} \mathrm{O}_{5}\right)$ is sikerült egydimenziós nanoszerkezeteket elóállítani [64-67]. A $\mathrm{TiO}_{2}$ kitüntetett szerepet tölt be a kutatásokban, mivel igéretes tulajdonságokkal rendelkezik a festékek [68], fogkrémek, fotokatalizátorok [69], napelemek [70], szenzorok [71] fejlesztésében. A titanát nanocsöveket, nanoszálakat, nanorudakat stb. szintén nagy érdeklődés övezi, köszönhetően széles felhasználási lehetôségeiknek és 
viszonylag egyszerú elóállítási módjuknak. A nanoméretú titanát struktúrák szintézisére az utóbbi években több módszert is kidolgoztak: hidrotermális-, szol-gél-, templát alapú- és elektrokémiai eljárásokat. Ezek közül a hidrotermális módszer bizonyult a leghatékonyabb megoldásnak a nanoméretû titanátok létrehozásában, melyet Kasuga és csoportja [72] alkalmazott először. Horváth és munkatársai továbbfejlesztett szintézismódszert valósítottak meg, melyben a kiülepedés megakadályozása érdekében speciális áramlásterelő elemekkel ellátott forgó autoklávban hajtották végre a reakciót [73]. Különleges sajátságaik nagy fajlagos felületükből és félvezetô tulajdonságaikból adódnak, így lehetôvé válik felhasználásuk a fotokatalízisben, lítium elemekben, szenzorokban, hidrogén előállításában és tárolásában, napelemekben és gyógyászati eljárásokban.

A nanocsövek kialakulásának egyik lehetséges magyarázata, hogy az alkalmazott körülmények között $\mathrm{TiO}_{2}$ kristálylapok tekerednek fel, ezáltal többfalú, csőszerú, mindkét végén nyitott struktúrákat hoznak létre. A falban, a $\mathrm{TiO}_{6}^{n-}$ oktaéderek által definiált rétegek közötti térben, kationok foglalnak helyet. A hidrotermális eljárás során több kristályforma előállítására van lehetôség: hidrogén titanát $\left(\mathrm{H}_{2} \mathrm{Ti}_{3} \mathrm{O}_{7}, \mathrm{Na}_{x} \mathrm{H}_{2-x} \mathrm{Ti}_{3} \mathrm{O}_{7}\right)$ [74, 75], ortorombos titanát $\left(\mathrm{Na}_{2} \mathrm{Ti}_{2} \mathrm{O}_{4}(\mathrm{OH})_{2}\right)$ [76] és tetratitanát $\left(\mathrm{H}_{2} \mathrm{Ti}_{4} \mathrm{O}_{9}\right)$ [77].

A titanát nanoobjektumokban a tiltott sáv szélessége csak kis mértékben tér el a tömbfázisú $\mathrm{TiO}_{2}$-tól, ennek ellenére megnövekedett fotokatalitikus aktivitással rendelkezhetnek, ami a kristályok kedvezőbb töltésvezetési képességével, nagyobb felületi hibahelykoncentrációval magyarázható [78]. Nagy fajlagos felületük döntően befolyásolja heterogén katalitikus reakciókban a reaktánsokkal kialakított kölcsönhatások erősségét [79]. A nanocsövek morfológiáját meghatározó tényezô az előállítási körülmény: $130{ }^{\circ} \mathrm{C}$-on 24 órás szintézisidő esetén $400 \mathrm{~m}^{2} \mathrm{~g}^{-1}, 107{ }^{\circ} \mathrm{C}$ hômérsékleten 48 órát követôen $280 \mathrm{~m}^{2} \mathrm{~g}^{-1}$ BET felületet mértek [80]. Umek és munkatársai $\mathrm{NO}_{x}$ gázok adszorpcióját vizsgálta nanocsövek felületén és EPR mérésekből megállapították, hogy a $\mathrm{NO}_{2}$ a titanát oxigénjeinek nemkötô py pályáin keresztül kapcsolódik a felülethez, ami a $\mathrm{TiO}_{2}$ alapú katalizátorok, nitrogén-oxid gázokkal végrehajtott reakciókban való felhasználási lehetőségét támasztja alá [81].

A titanát nanocsövek híg szervetlen savakban, szobahőmérsékleten néhány hónap alatt átalakulnak rutillá. $175{ }^{\circ} \mathrm{C}$-on végzett hidrotermális kezelés polikristályos, nanostrukturált anatázt eredményezett [82], hasonlóan ahhoz, mikor savas közegben végezték a kísérletet [83]. Bavykin és munkatársai arra a következtetésre jutottak, hogy a nanocsövek megőrzik stabilitásukat, illetve csak kismértékú morfológiai változásokon esnek át tiszta vízben és bázikus $(0,1 \mathrm{M} \mathrm{NaOH})$ közegben [84]. Az átalakulás sebességét az alkalmazott savak anyagi minôsége is befolyásolja. $0,1 \mathrm{M} \mathrm{H}_{2} \mathrm{SO}_{4}$ oldatban szuszpendáltatva lassan rutil nanorészecskékké alakulnak, amik később ellipszoidális alakú fázisokká egyesülnek. 0,1 M $\mathrm{HCl}$ és $\mathrm{HNO}_{3}$ oldatokban az átalakulás kisebb sebességgel játszódik le, mint ugyanilyen töménységú $\mathrm{H}_{2} \mathrm{SO}_{4}$-ban, továbbá a $\mathrm{Ti}^{4+}$ ionok is kisebb koncentrációban találhatók a folyadék 
fázisban.

A titanát nanocsövek fizikai behatásokkal szemben kevésbé ellenállóak és könnyen kisebb darabokra töredeznek, ha mechanikai erôk hatnak rájuk. Ultrahangos kezelésnek kitéve őket, rövidebb hosszúságú fragmensekre esnek szét [85]. Hőhatással szemben sem ellenállók, a $\mathrm{H}_{2} \mathrm{Ti}_{3} \mathrm{O}_{7}$ nanocsövek $400{ }^{\circ} \mathrm{C}$ felett rácsoxigént veszítenek és rúd-szerú képződményekké alakulnak át. Az elvégzett kutatások kimutatták, hogy $120-400{ }^{\circ} \mathrm{C}$ tartományban vízvesztés következik be, és a kiindulási $\mathrm{H}_{2} \mathrm{Ti}_{3} \mathrm{O}_{7}$ csövek $\beta-\mathrm{TiO}_{2}$ struktúrává alakulnak át, miközben a falat alkotó rétegek egymáshoz viszonyított távolsága lecsökken [86,87]. Ha tovább növeljük a hômérsékletet $700{ }^{\circ} \mathrm{C}-\mathrm{ra}$, a $\beta-\mathrm{TiO}_{2}$ nanocsövek anatáz nanorudakká alakulnak, elveszítve csőszerú struktúrájukat, majd $1000{ }^{\circ} \mathrm{C}$-on rutilkristályok formálódnak [88]. A nanoszálak, a nanocsövekhez képest nagyobb hőstabilitással rendelkeznek, kristályszerkezetüket és morfológiájukat 200-600 ${ }^{\circ} \mathrm{C}$ tartományban képesek megőrizni [80].

A nátrium ionok szerepét Suetake és munkatársai eredményéből ismerhetjük meg pontosabban [89]. Kutatásukból az derült ki, hogy a $\mathrm{Na}^{+}$ionok egy gyenge és egy erős kötőhelyhez kapcsolódhatnak. Erôs kölcsönhatás a nanocsövek falát alkotó rétegek közötti térben jön létre, mely a tubuláris szerkezet stabilitását markánsan befolyásoló tényező. A hőmérséklet hatására bekövetkező szerkezeti átalakulás ezen kationok pozíciójának megváltozásával áll szoros kapcsolatban $[90,91]$. A nanocsövek ion-kicserélődési reakciókban is részt vehetnek, ahol a falat alkotó rétegek közötti térbe épülnek be az idegen ionok. Alkálifémek ionjait $\left(\mathrm{Li}^{+}, \mathrm{Na}^{+}, \mathrm{K}^{+}, \mathrm{Rb}^{+}, \mathrm{Cs}^{+}\right)$tartalmazó vizes ammónia oldatokban tanulmányozták a rendszer ezen tulajdonságát [92]. Továbbá átmenetifémek ionjaival $\left(\mathrm{Co}^{2+}, \mathrm{Ni}^{2+}, \mathrm{Cu}^{2+}, \mathrm{Zn}^{2+}, \mathrm{Cd}^{2+}\right)$ kapcsolatos méréseket is találunk az irodalomban [75]. Az idegen ionok nem befolyásolják a rétegek közötti távolságot, vagyis a titanát kristályszerkezetében számottevő módosulást nem váltanak ki. Kim és Cho tanulmányukban kimutatták, hogy nanoszálak és nanocsövek BET felülete növekszik az ioncsere hatására [93]. Nanocsövek esetén $99 \mathrm{~m}^{2} \mathrm{~g}^{-1}$-ról 243 $\mathrm{m}^{2} \mathrm{~g}^{-1}$-ra növekedett a felület, mikor kobalttal végrehajtott ioncserét alkalmaztak. $\mathrm{A} \mathrm{TiO}_{2}$ nanoobjektumokhoz komplex mágneses tulajdonságok is rendelhetők, ha megfelelő ionokkal végezzük a dópolást. $\mathrm{Ni}^{2+}$ ionokkal végrehajtott ion-kicserélődést követôen a rendszer mágnesességét a beépített ionok mennyiségével lehet szabályozni [94].

A titanát nanocsövek a széles tiltott sávval rendelkező félvezetők közé sorolhatók. Vizes kolloid fázisban, szobahőmérsékleten mért sávszélességük 3,87 eV [95], ami nagyon közel esik a 2D struktúrájú titanát nanorendszerek 3,84 eV-os értékéhez [96], és távolabb van a tömbfázisú $\mathrm{TiO}_{2} 3,2 \mathrm{eV}$ energiájától. Abszorpciós és lumineszcencia vizsgálatok nem mutattak eltérést a spektrumok sávjainak pozíciójában, mikor a nanocsövek belső átmérője 2,5-5 nm között változott. Az egydimenziós $\mathrm{TiO}_{2}$ nanocsövek és a kétdimenziós struktúrák elektronszerkezete nagyban hasonlít egymásra, ami az optikai tulajdonságaik nagyfokú hasonlóságában is visszaköszön [95]. A fotokatalitikus aktivitás növelésének több módja 
is ismert, mint például a fajlagos felület növelése [97], a nanostruktúrák kristályosságának növelése [98], fémek hozzáadása [99]. A kristályos tulajdonság növelését Khan és csoportja [98] a $\mathrm{NaOH}$ oldatban végrehajtott hidrotermális eljárás útján nyert nanocsövek hidrogén-peroxidos utókezelésével oldotta meg. Az így nyert termék közel kétszer nagyobb fotokatalitikus aktivitással rendelkezett a trimetilamin oxidációs reakciójában, mint a hagyományos titán nanocső, vagy a Degussa P25 titanát. A fém hozzáadására megnövekedett aktivitásra példaként Jang és munkatársai közleményét említhetjük [99], akik nikkel tartalmú nanocsöveken figyeltek meg fotokatalitikus aktivitásnövekedést a fémet nem tartalmazó nanocsövekhez képest, miközben metanol/víz elegyből történő hidrogén képződést vizsgáltak UV besugárzás hatására.

\section{3. $\quad \mathrm{TiO}_{2}$ felületek vizsgálata XPS módszerrel}

A $\mathrm{TiO}_{2}$ és a $\mathrm{TiO}_{2}$ hordozós fémek XPS vizsgálatának irodalma szerteágazó, ebben a fejezetben az általunk is vizsgált minták esetében kapott eredményeket próbálom röviden összefoglalni. Számos közlemény fellelhető a tudományos irodalomban, melyek a fém titán és az oxidban található Ti(IV) kötési energiáját ismertetik. A Ti ${ }^{4+} 2$ p elektronjainak XPS-sel meghatározott kötési energiája, a különböző módon előállított és kezelésnek alávetett $\mathrm{TiO}_{2}$ mintákban, zavarba ejtően széles határok között mozog. A teljesség igénye nélkül néhány adatot megemlítve: 457,9 eV [104], 458,6 eV [105], 459,1 eV [106], 459,3 [107], 459,8 eV [108]. Ennek a változatosságnak egyik oka, hogy a titán-dioxid felületén kialakuló oxigénhibahelyek sávelhajlást okoznak a vegyértékelektronok potenciálterében, ami a törzselektronok kötési energiáját is módosítja [107]. A szintézismódszertôl függően különbözô felületi hibahelykoncentráció jellemzi az adott mintát, ami a detektált kötési energiák irodalmi értékeinek szórását is magyarázhatja. Godfroid és munkatársai $\mathrm{SnO}_{2}$ felületen növesztett fém Ti filmeket vizsgáltak annak érdekében, hogy pontosabb betekintést nyerjenek a néhány tized nanométer vastagságú rétegek képződését kísérô kémiai változások mechanizmusába [100]. Ennek keretében meghatározták a csúcspozíciók pontos helyét és Doniach-Sunjic, aszimmetrikus függvényeket használva végezték el a titán spektrum csúcsfelbontását. Az összetett spektrumban a $2 \mathrm{p}_{3 / 2}$ jele $\mathrm{Ti}^{0}{ }^{-}$nál 452,2 eV, a Ti ${ }^{2+}$-nál 455,2 eV, a Ti ${ }^{3+}$-nál 457,2 eV, míg a $\mathrm{Ti}^{4+}$-nál 458,8 eV kötési energia értéknél található. A folyamatban az ón hordozó felületi redukcióját, ezzel párhuzamosan a titán oxidációját figyelték meg. Pouilleau és munkatársai titán fém hordozón kialakított, különböző vastagságú és összetételú titán-oxid rétegeket tanulmányoztak XPS és más felületvizsgáló módszerekkel [101]. Ebben megállapították, hogy kívülrôl egy 10-20 nm vastagságú, amorf $\mathrm{TiO}_{2}$ réteg jön létre, alatta egy $\mathrm{TiO}_{x}$ redukált fázis foglal helyet. A rendszer korrózióval szembeni ellenállóképességét a külsô réteg vastagsága szabja meg. Abban az esetben mikor szilikon karbid papírral és Buehler alumina 
szuszpenzióval kezelték a tiszta titán lemez felületét, a képződő oxidban a Ti $2 \mathrm{p}_{3 / 2}$ pálya kötési energiáját 464,8 eV-nál, míg galvanosztatikus kezelést követően 464,5 eV-nál találták. McCafferty és Wightman szintén titán felületen létrejött oxidréteget vizsgáltak, melyben 3 $\mathrm{keV}$ energiájú $\mathrm{Ar}^{+}$ionos bombázást követően rögzített XP spektrumok segítségével mélységprofilt határoztak meg [102]. Ebből megállapították, hogy a külsố réteg $\mathrm{TiO}_{2}$ összetételú, míg a belsố régióban +3 és +2 oxidációs állapotú titán jelenlétére derített fényt az aszimmetrikus Ti 2 p spektrumok csúcsfelbontása. Tanulmányukban az ionsugárzás redukáló hatását is feltételezték. González-Elipe és munkatársai $\mathrm{Ni}(\mathrm{II})$-t tartalmazó $\mathrm{TiO}_{2}$ minták összetételváltozását elemezték 3,5 keV energiájú $\mathrm{Ar}^{+}$ion bombázás hatására [103]. Azt találták, hogy a $\mathrm{Ti}^{4+}$ stabilitása növekszik a $\mathrm{Ni}^{2+}$ jelenlétében, míg a nikkel könnyebben redukálódik fém állapotúvá, mint a tiszta NiO-ban.

A $\mathrm{TiO}_{2}$ rutil (110) felületi oxigénjeinek XPS mérések és DFT számolások útján nyert eredményeit Perron és munkatársai cikke részletezi [109]. Mikor a $\mathrm{TiO}_{2}$ felületre meróleges irányból vették fel az O 1s spektrumokat, három komponenst találtak: 529,7 eV-nál a tömbfázisra jellemző oxigének jelét, 531,0 eV-nál a kétfogású oxigénekét és 532,2 eV-nál az egyfogású oxigénekét. Utóbbi kettô a felülethez köthetô atomoktól származik, melyet a minta $70^{\circ}$-os megdöntése utáni jelintenzitásnövekedés is alátámasztott, mivel ez a változtatás a mérés felületérzékenységét növelte. A röntgensugárzás beesési szögének módosítása egy negyedik komponens megjelenését is maga után vonta 533,5 eV kötési energiánál, ami a felületen nagyon kis mennyiségben jelen lévő víztôl származott.

A nemfémes hordozóra felvitt kisméretű fémrészecskék elektronszerkezetének vizsgálata fotoemissziós technikákkal nagy múltra tekint vissza. Az XPS segítségével lehetőség nyílik a kis koncentrációban, hordozók felületére felvitt fémrészecskék elektronrendszerének mélyebb megismerésére. Ennek a tulajdonságnak a feltárása rávilágít a fém-hordozó közötti kölcsönhatások természetére is, melynek rendkívül lényeges szerepe van egy adott fém katalitikus tulajdonságainak kialakításában. A fémklaszterek méretének csökkenése a mért kötési energiák növekedését vonja maga után [110]. A részecskeméret csökkenésével párhuzamosan egyre kisebb szerepet játszik a szomszédos atomok vegyértékelektronjai által biztosított extra-atomi relaxációs hatás (screening effect), így a mért kötési energia egyre inkább az izolált atomokra vonatkozó érték felé tolódik el [111-113]. Bahl és munkatársai platinát vizsgáltak $\mathrm{SrTiO}_{3}$ egykristály felületen és a Pt 4f pályák kötési energiájának csökkenésérôl számoltak be a Pt borítottság növekedésével [114].

A fémklaszterek méretének csökkenése nem csak a kötési energia növekedésében érhető tetten, hanem az XP jel félértékszélességének (FWHM) növekedését is maga után vonja $[115,116]$. A méretcsökkenésből adódó jelkiszélesedés okaként a klaszterek méretének inhomogenitását, az elektronlyuk élettartalmának növekedését lehet megemlíteni. A félértékszélesség nagymértékben függ ugyanis a relaxáció mértékétől és fordított arányban 
van az árnyékoló (screening) hatással. Elméleti eredmények is alátámasztják ezt a megfigyelést, többek között Ascarelli csoportja foglalkozott a kérdéssel, akik teflon hordozón elhelyezett kisméretú arany klasztereket tanulmányoztak, és 1 eV körüli FWHM kiszélesedést határoztak meg [117].

Wu és munkatársai ultravékony $\mathrm{Al}_{2} \mathrm{O}_{3}$ film felületen növesztett $\mathrm{Cu}$ klasztereket vizsgáltak $80 \mathrm{~K}$ és $300 \mathrm{~K}$ hőmérsékleten XPS segítségével [115]. A réz oxidációjára, vagy erős Al-Cu kölcsönhatás kialakulására utaló jeleket nem tapasztaltak az XP spektrumok kiértékelésekor. Kis $\mathrm{Cu}$ borítottságnál a $\mathrm{Cu} 2 \mathrm{p}_{3 / 2}$ csúcs nagyobb kötési energiánál adódott, míg a röntgensugárzás által generált $\mathrm{Cu} \mathrm{L}_{3} \mathrm{M}_{4,5} \mathrm{M}_{4,5}$ Auger elektron mozgási energiája kisebb volt a tömbfázisú rézhez viszonyítva. Cikkükben az Auger paramétert használták arra, hogy a final-state (a fotoionizációt követôen a törzselektronok szintjén kialakult pozitív töltésú lyukra adott extra-atomi válaszok) és az initial-state hatások (fotoionizációt megelőzően kialakult vegyértékelektron konfiguráció), $\mathrm{Cu} 2 \mathrm{p}_{3 / 2}$ kötési energiához való hozzájárulását elkülönítsék. A kis méretű klasztereken számolt initial-state eltolódás negatív értéket vett fel, ami a fémrészecskéken belüli csökkent $\mathrm{Cu}$ koordinációs számmal van összefüggésben. 80 K-en nagyobb eltolódást kaptak, ami igazolja, hogy alacsonyabb hômérsékleten kisebb méretű klaszterek képződtek. A pozitív előjelú final-state hozzájárulás ugyanolyan borítottság mellett, magasabb hőmérsékleten kisebb volt, amit szintén a részecskeméret változással magyaráztak a szerzők.

Scott Anderson és munkatársai 2005-ben megjelent cikkükben $\mathrm{TiO}_{2}(110)$ felületre felvitt, néhány atomból álló $\mathrm{Au}_{n}^{+}$klaszterek $\mathrm{CO}$ adszorpcióban mutatott viselkedését tárgyalják XPS és LEIS mérésekre támaszkodva [118]. $\mathrm{Au}_{1}^{+}$és $\mathrm{Au}_{2}^{+}$esetén $\mathrm{CO}$ oxidációban kisebb aktivitást tapasztaltak, mint magán a $\mathrm{TiO}_{2}$ hordozón. Az aktivitás csökkenés véleményük szerint $\mathrm{az} \mathrm{Au}_{1}^{+}$és az $\mathrm{Au}_{2}^{+}$oxigénvakanciákhoz kötődése miatt következik be, ezáltal blok-

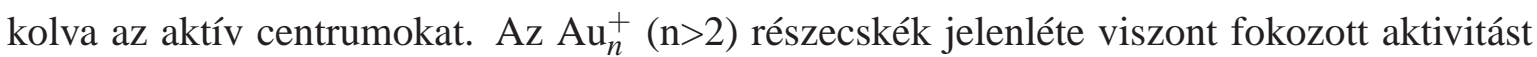
eredményezett, mivel itt már nem az oxigén hibahelyek, hanem az arany nanorészecskék biztosították a reakciócentrumokat. Kisenergiájú ionszórásos spektroszkópiás (LEIS) mérések alapján az arany agglomerizációja nem következik be $450 \mathrm{~K}$ alatt, $\mathrm{Au}^{+}$esetén aktivitásnövekedés figyelhető meg $400 \mathrm{~K}$ felett. $115 \mathrm{~K}$-rôl indulva $600 \mathrm{~K}$-re melegített, aranytartalmú hordozók Au 4f spektrumainak eltolódását figyelték meg. $115 \mathrm{~K}$-en atomosan diszpergált Au található a felületen, melynek $4 \mathrm{f}_{7 / 2}$ kötési energiája 85,8 eV-nak adódott. Felfütés hatására ez az érték csökkent, 300 K-tôl 85,4 eV-ra, 450 K felett 84,5 eV-ra, ami a részecskeméret növekedését igazolja. Ha olyan $\mathrm{TiO}_{2}$ felületre adszorbeált aranyat analizáltak, melyen nagy volt az oxigén hibahelyek koncentrációja, az Au 4f $\mathrm{f}_{7 / 2}$ csúcs fökomponensét 85,4 eV energiánál detektálták. Ez azt bizonyítja, hogy 300-450 K hőmérsékleten az arany a felületi vakanciákhoz kötődik.

Fémek CO adszorpció hatására bekövetkező XP jelének eltolódását gyakran a Blyholder 
modell [119] segítségével értelmezik. Ebben a modellben a fém-CO kötés kialakulása két részből tevődik össze. Egyfelől egy $\sigma$ kötés jön létre a $\mathrm{CO}$ betöltött $5 \sigma$ pályája és a fém betöltetlen nívója között lejátszódó elektron átmenet révén, másrészt egy $\pi$ kötés is létesül a fém d-elektronjai és a CO üres $2 \pi^{*}$ pályái közötti visszadonációnak köszönhetôen. Mivel az XPS érzékeny az elektronsúrúség változására, segítségével az elektronok $\sigma$ és $\pi$ kötésekhez való hozzájárulásának arányára következtethetünk.

Anderson-ék dolgozatukban [118] az izolált arany atomok 4f pályáinak kötési energia növekedését tapasztalták CO hatására, ami az arany elektronvesztésére utal az Au-CO kötés kialakulása során. Így a Blyholder modell alapján arra következtettek, hogy az arany esetén a $\pi$ visszadonáció dominánsabb tényező, mint a $\sigma$ kötés létrejötte. Ezt a feltételezést támasztják alá Meier és munkatársai UPS és IR mérési eredményei is [120]. 


\section{4. fejezet}

\section{Kísérleti rész}

\subsection{XPS, LEIS módszerek rövid áttekintése}

Heterogén katalitikus vizsgálatok során az érdeklődés középpontjában álló kémiai történések a szilárd katalizátor felületén játszódnak le. Az ilyen típusú folyamatokat olyan vizsgálati technikák alkalmazásával lehet közelebbről megismerni, melyek közvetlenül a felületről szolgáltatnak értékes kémiai információkat. Mind a röntgen-fotoelektron spektroszkópia (XPS) mind pedig a kisenergiájú ionszórási spektroszkópia (LEIS) egy lehetséges módszer az előbb megfogalmazott kívánságra. Az alábbiakban ezen két módszer rövid összefoglalását adom meg, az általunk használt készülék infrastruktújára helyezve a hangsúlyt.

A vizsgálni kívánt szilárd anyaggal kapcsolatban kezdetben rendelkezésünkre álló információ mennyiségének növelése, a kötési energia, mint valószínúségi változó, által felvett érték váratlanságának várható értékének csökkentése érdekében a röntgen fotoelektron spektroszkópia megfelelő energiájú (1250 - 4000 eV) röntgenfotonokat használ. A röntgensugárzás hatására a mintából távozó fotoelektronok kinetikus energiáját $\left(\mathrm{E}_{k}\right)$ megmérve és a kapott értéket a gerjesztő fotonok ismert energiájából (hv) kivonva, a kérdéses elektronhéj kötési energiájáról $\left(\mathrm{E}_{b}^{F}\right)$ nyerünk felvilágosítást:

$$
h v=E_{b}^{F}+E_{k}+\phi,
$$

ahol $\mathrm{E}_{b}^{F}$ a Fermi-szintre vonatkoztatott kötési energia, $\phi$ a spektrométer kilépési munkája, mely utóbbi megegyezik a készülék Fermi-szintjének és a vákuum szint energiakülönbségével. A fizikai kontaktus eredményeként a vizsgált minta és a spektrofotométer Fermi-szintje megegyezik.

A fotoelektron kinetikus energiáját az atom elektronkörnyezete is befolyásolja, ami az anyagi minőség meghatározásán túl a kérdéses elem oxidációs állapotára, kémiai környezetére vonatkozó ismeretekbe is betekintést enged. A röntgentartományból származó foton 
ionizációs hatáskeresztmetszete a lezárt héjak elektronjaira nézve maximális, így a belsố ionizáció révén távozó elektronok analízise válik lehetségessé, míg a vegyértékelektronok XP spektruma kevésbé informatív. A fotoelektronok a szilárd fázisból történő távozásuk elôtt rugalmatlan ütközések révén energiájuk egy részét elveszítik, szabad úthosszuk megfelelően kis érték ahhoz, hogy a felületérzékeny módszerek kategóriájába sorolhassuk az eljárást. Az elektronok azon hányada, melyek energia veszteség nélkül távoznak a felülettől mért $l$ mélységből, egy valószínúséggel jellemezhetô: $e^{\frac{l}{\lambda}}$, ahol $\lambda$ a rugalmatlan ütközés szabad úthossza. Bevett szokás XPS-ben a kiértékelés szempontjából értékes jelet az $l=0-3 \lambda$ mélységből érkező elektronokhoz kötni.

A röntgensugárzást egy anódfém, ami leggyakrabban alumínium vagy magnézium, nagyenergiájú elektronokkal történő besugárzásával állítják elő. Az általunk használt röntgenágyú mindkét lehetőséget tartalmazta, megkönnyítve ezzel a felvett spektrumok átfedő fotoelektron és Auger-elektron csúcsainak elkülönítését. A mintából távozó elektronok egy fókuszáló elektronoptikán áthaladva jutnak a kinetikus energiájuk szerinti szétválogatásra tervezett félgömb analizátorba. Annak érdekében, hogy ezen megtett viszonylag hosszú út során a kinetikus energia formájában hordozott kémiai információra szuperponálódó zaj torzító hatását minimálisra csökkentsük, ultravákuum alkalmazása szükséges. Ennek a $10^{-8}-10^{-10}$ mbar nyomásnak az előállítása elővákuum pumpák és turbomolekuláris szivattyúk segítségével valósult meg. Az ultravákuum alkalmazásának további előnye, hogy megakadályozza az elektronágyú fém izzószálának korrózióját, illetve minimalizálja a gáztér komponenseinek felületre történő adszorpcióját.

Az elektronspektroszkópiában használatos analizátorok két jellemző tulajdonságát érdemes megemlíteni: transzmissziójukat és felbontásukat. Az ideális spektrum nagy intenzitású és nagy felbontású, egymástól elkülönülő jelből állna. Ha az analizátor transzmisszióját nagy értéknek választjuk, akkor a jelintenzitás növekszik a felbontás rovására. Ha viszont a transzmissziót csökkentjük le, például az analizátor belépő résének csökkentésével, akkor a felbontás fog javulni, viszont az intenzitás lesz kisebb. Az XPS készülékeknél használatos félgömb analizátorok (HSA) az elektronoptika és az elektronsokszorozó segítségével mindkét kritériumnak magas szinten képesek megfelelni.

A fotoelektronok kinetikus energiáját félgömb analizátorral határoztuk meg, ami felépítését tekintve egy elektrosztatikus elven múködő félgömb kondenzátor, melynek fegyverzeteire kapcsolt potenciálkülönbség biztosítja a mozgási energia szerinti szeparációhoz szükséges elektrosztatikus teret. A mozgási energia meghatározása azon az elven alapul, hogy adott potenciálkülönbség mellett a belépő elektronok pályasugara sebességüktôl függő mennyiség. Mivel a mintából távozó elektronok kinetikus energiája túlságosan nagy ahhoz, hogy nagyfelbontású spektrumokat vehessünk fel, ezért le kell lassítani azokat. A lefékezést kétféleképpen valósítják meg: FAT (fixed analyser transmission)-, illetve FRR (fixed retarda- 
tion ration)-módszer segítségével. FAT üzemmódban az elektronok energiáját egy megadott értékre csökkentik, vagy növelik, mellyel az analizátoron történő áthaladásuk során rendelkezni fognak (pass energy). Kis pass energy mellett nagyobb felbontást érhetünk el, nagyobb pass energy esetén pedig nagyobb transzmissziót, de rosszabb felbontást. Mivel ebben az üzemmódban az analizátor félkörelektródjai között állandó potenciálkülönbség van, ezért a felbontás sem fog változni a rögzített spektrumokon. FRR üzemmódban az elektronokat eredeti energiájuk konstans szorosára fékezik, ekkor a pass energy a kinetikus energiával arányos érték. Ebben az esetben a felbontás nem állandó érték, a nagyobb kinetikus energiák tartományában egyre rosszabbá válik. Mivel a mozgási energia növekedése a transzmisszió növekedését vonja maga után, ezért a lassú elektronoktól származó spektrális jeleket el lehet nyomni FRR-módban. Mivel az analizátoron átjutott elektronok száma a jelfeldolgozás szempontjából túl alacsony, ezért ez egy elektronsokszorozó (channeltron multiplier) beiktatását is szükségessé teszi, amely folytonos sokszorozást tesz lehetővé. Az adatfeldolgozás további lépése már számítógéppel történik, megfelelő szoftverek segítségével.

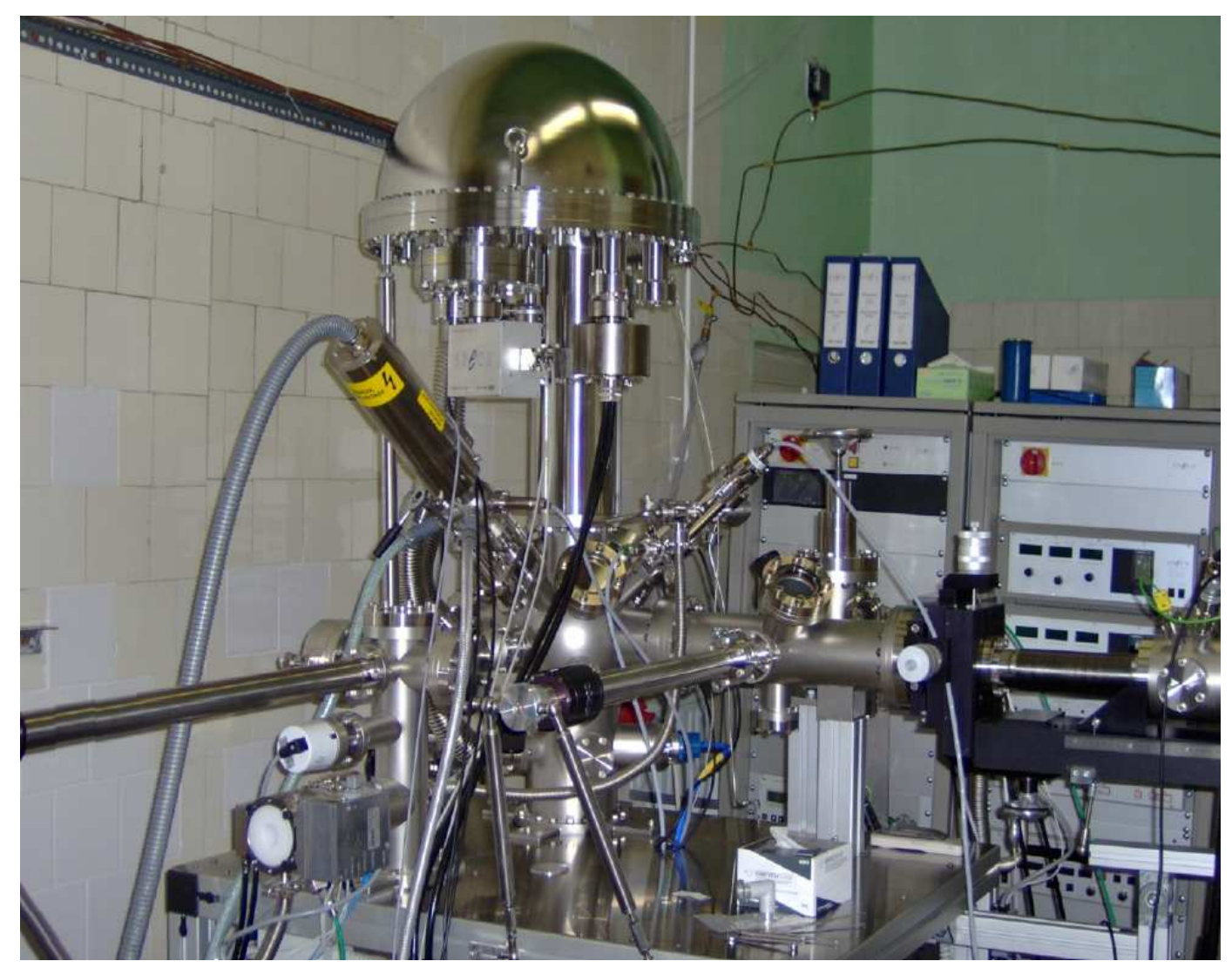

4.1. ábra. Az XPS készülék

XPS készülékünk (4.1. ábra) ionágyújának segítségével lehetőség volt töltéssel rendelkező gázrészecskék előállítására, melyeket az alkalmazott gyorsítófeszültség nagyságának függvényében, különböző célokra használhattunk fel. Erre egyfelől akkor lehet szükség, ha 
mélységi profilt szeretnénk felvenni, melynek érdekében el kell távolítani a felső néhány atomréteget, vagy ha a minta felületének tisztítását kell elvégezni. Ezt a módszert akkor használhatjuk, ha az ionbombázás hatására nem következik be a minta felületkezelés után visszamaradt részének, az eredetihez képest szerkezetbeli illetve összetételbeli változása. Ilyen esetekben 2-3 kV feszültséggel felgyorsított argont ionokat használtunk. LEIS spektrumok felvételéhez is az ionágyú szolgáltatta a szükséges töltéssel bíró részecskéket. A mintafelület destrukciójának elkerülése fontos szempont, ezekben az esetekben $800 \mathrm{~V}$ feszültséggel gyorsított He ionokat alkalmaztunk.

A LEIS spektrumok az XPS-hez viszonyítva csakis a legfelső atomrétegrôl szolgáltatnak felvilágosítást, melynek az a magyarázata, hogy az alkalmazott gázionok töltésének megmaradása gyakorlatilag nulla valószínúségúnek tekinthető, ha annak alkalma nyílik behatolni a felületet alkotó atomok közé, így semleges részecskeként távozva az analizátorban jelet kiváltani már nem képesek. A módszer lényegében azon alapul, hogy a vizsgálandó mintát adott szögben kis energiájú ionokkal lőjük meg, a felületrôl visszaszóródó gázionok kinetikus energiáját pedig a félgömbanalizátor segítségével határozzuk meg. Mivel a szóródás rugalmasnak tekinthetô, így a beesési szög, a részecske tömegének, az ütközés elôtti és utáni mozgási energiájának ismeretében, az impulzus- és energiamegmaradás tételéből levezethető összefüggés birtokában megállapítható, hogy az ütközés milyen tömegú atommal következett be, ami elemanalízist tesz lehetővé.

Az XPS berendezést három nagyobb részre lehet felosztani, mely fizikai egységeket kapuszelepek segítségével tudtuk elkülöníteni egymástól, ha valamelyik egységben a mintacsere vagy a minta kezelése miatt a vákuum helyett atmoszféra nyomású gázok alkalmazása vált szükségessé. Ezzel elkerülhettük a teljes készülék leállását, és csak a kívánt egységet érintette a változtatás, mivel mindegyikben önálló pumparendszer gondoskodott az ultravákuumról. A minta készülékbe helyezése/kivétele a preparáló kamrában (load-lock) történt, az atmoszférikus nyomás eléréséhez nitrogéngázt használtunk. Lezárás és a megfelelô nyomás elérése után a mintát egy manipulátor rendszerrel az analíziskamrába továbbítottuk, ahol az XP és LEIS spektrumokat rögzítettük. Innen helyezhettük a vizsgált anyagot a nagynyomású katalíziskamrába (4.2. ábra), ha erre szükség volt. A mintamozgatást egy összetett manipulátrorrendszer biztosította, mellyel vízszintes és függőleges irányú pozícionálást is végezhettünk az analízis- és a katalízis kamra között.

Az elvégzett katalitikus mérések a berendezéshez közvetlenül kapcsolódó nagy nyomású kezelőkamrában történt. Ebben az elrendezésben lehetôség volt a minta programozott felfútésére, a reakcióhoz szükséges atmoszféra nyomású gázok be- illetve elvezetésére. A gázáramlást a készülékhez csatlakoztatott, külön panelen elhelyezett nyomáscsökkentőkből, golyós áramlásmérôkbőll illetve tömegáram szabályozókból álló rendszer biztosította. Ez az elrendezés lehetőséget teremtett arra, hogy a kinetikai vizsgálatokkal azonos kísérleti para- 


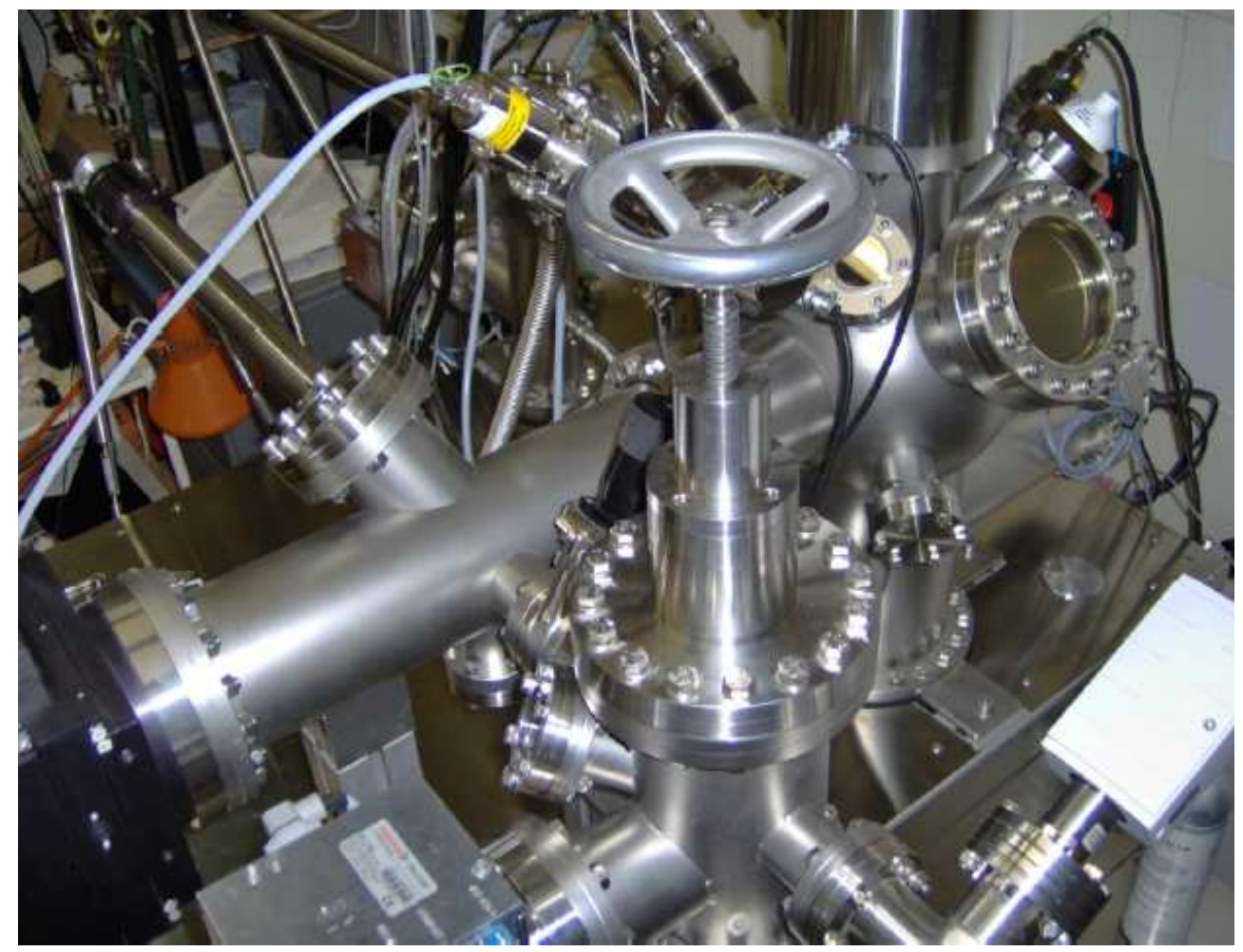

4.2. ábra. A nagynyomású kezelőkamra

méterek mellett végrehajtott reakciót követôen a katalizátorok felületén bekövetkező változásokat tanulmányozzuk. A katalízis cella és az XPS készülék összekapcsolásának elônye abban rejlik, hogy a reakciót követôen a minta nem érintkezik a levegővel, így annak mérési eredményt meghamisító hatása kiküszöbölhetővé válik. Ennek a szerepe méginkább felértékelődik, ha a kérdéses katalizátort több lépcsôs reakció-spektrumfelvétel sémában vizsgáljuk.

\subsection{XP spektrumok fóbb jellemvonása}

A karakterisztikus röntgensugárzás hatására generált fotoelektronok kinetikus energiájából az anyag elektronjainak diszkrét kötési energiáját nyerjük. A kötési energia függvényében ábrázolt beütésszám definiálja magát a röntgenfotoelektron spektrumot, ahol a csúcs helyéből a kvalitatív, míg területéből a kvantitatív jellegú információk nyerhetők ki.

Alapesetben egy XP csúcs vagy szingulett vagy dublettet alkotó pár, ami a spin-pálya csatolás következtében jön létre. Röviden itt arról van szó, hogy az elektron atommag körüli mozgásának eredményeként előálló mágneses tér és a spinhez köthetô mágneses tér nem függetlenek egymástól és csatolásuk révén az elektron energiájában is eltérések adódnak, az XP spektrumokon is látható felhasadást eredményezve. Mindez a nullánál nagyobb mellékkvantumszámú pályák esetén áll fenn, így az s pályákról származó fotoelektronok jele általában 
nem hasad fel. A dublett tagjainak intenzitásaránya az egyes tagok mágneses kvantumszámai által meghatározott elfajultság arányaként adódik.

A csúcs alatti terület meghatározásával lehetőség nyílik a felületet alkotó atomok százalékos összetételének meghatározására. Így az a megállapítás, hogy a fotoelektron csúcsok intenzitása függ a vizsgált mintától, az előzőek fényében triviálisnak hat. Viszont van két további tényezố is, melynek megemlítését fontosnak tartom. Az egyik, öszefoglaló néven, a készülék múködési paraméterei, ahol gondolhatunk a röntgenágyú teljesítményére, az analizátor beállított múködési paramétereire, a minta felületi normálvektorának és az analizátor belépő nyílásának középvonala által bezárt szögére, amik a készülék használata során módosítást igényelhetnek. További tényező a fotoionizációs hatáskeresztmetszet, ami kifejezi, hogy adott energiájú röntgensugárzás különböző valószínúséggel fog fotoelektronokat kiváltani más-más kötési energiájú pályákról. Ezt a paramétert minden elem, minden pályájára meghatározták és a kiértékelő szoftverekbe is beépítették, így mennyiségi analízis elvégzéséhez automatikusan rendelkezésre állnak.

A felvett spektrumokon látható csúcsok ritkán szimmetrikus lefutásúak, aminek több oka is lehet. Ha ugyanazon kémiai minőségú elem különböző oxidációs állapotban vagy különböző kémiai környezetben van jelen, akkor ezek eltérő kötési energiával rendelkeznek, így különböző csúcspozíciójú és intenzitású jelek szuperpozíciója révén szolgáltatják a spektrumot. Mivel ez esetben a készülék felbontóképessége már nem elegendő ahhoz, hogy ezek a csúcsok elkülönüljenek, így utólag dekonvolúció segítségével kell a komponenseket kinyerni, ami nem mindig könnyú és egyértelmú feladat. Sikeres csúcsfelbontás esetén a különböző oxidációs állapotok részaránya is megállapítható.

Mivel egy elektron emissziójával egy gerjesztett, instabil energiaállapotú ion marad vissza, ezért a rendszer relaxációs folyamatok révén igyekszik energetikailag kedvezőbb állapotba kerülni. A többletenergia távozhat karakterisztikus röntgensugárzás formájában illetve hozzájárulhat Auger elektronok kilépéséhez is. Ez utóbbi esetben a fotoelektron távozásával visszamaradt vakanciát egy magasabb nívón tartózkodó elektron tölti be, az energiakülönbség pedig egy harmadik elektron eltávolítására fordítódik. Értelemszerúen az analizátor nem tud különbséget tenni Auger- és fotoelektron között, ezért mindkettő megfigyelhető a spektrumban. Ez még önmagában nem jelentene gondot, ha ezek minden esetben jól elkülönülnének egymástól. A valóságban viszont gyakran átfednek, mely problémát a röntgenágyú anódváltásával könnyen megoldhatjuk. Ha a spektrumot kötési energia függvényében rögzítjük, a fotoelektronok csúcspozíciója invariáns az anódváltásra nézve, míg az Auger csúcs a kétféle anód által szolgáltatott röntgensugárzás energiabeli különbségével azonos eltérést mutat, mivel az Auger-rekombinációból származó elektron kinetikus energiája nem függ a gerjesztő röntgenfoton energiájától.

A fotoelektronok kinetikus energiája az említett relaxációs mechanizmusok által is mó- 
dosulhat. A gerjesztett állapotú ion energiát vehet fel tőle, ezáltal vegyértékelektronok kerülnek betöltetlen szintekre. Ebben az esetben a mért kinetikus energia kisebb lesz, ami a számított kötési energia növekedését jelenti, a spektrumon pedig a kérdéses fotoelektroncsúcs nagyobb kötési energiájú oldalán megjelenô energia veszteségi vagy más néven shakeup szatellitként figyelhető meg. Ha viszont a fotoelektron energiát vesz fel az iontól, akkor energia nyereségi (shake-down) szatellitről beszélünk. A szatellit vonalak megléte vagy hiánya gyakran hasznos információt szolgáltat a szóban forgó elem oxidációs állapotát illetôen. Szintén a nagy kötési energiájú oldalon jelentkeznek a plazmon veszteségi csúcsok, melyek az elektrongáz kollektív mozgásállapotának gerjesztéséből származó veszteségként értelmezendők. Itt megkülönböztethetünk felületre, illetve tömbfázisra jellemző plazmongerjesztéseket, melyek eltérô energiájuknál fogva elkülönülnek egymástól az XP spektrumokon.

Egy spektrummal kapcsolatos további jellegzetesség, hogy a csúcsok egy folytonos háttéren foglalnak helyet. Egy FAT üzemmódban múködtetett analizátor esetén a kisebb kinetikus energiák oldalán lényegesen magasabb a háttérszint, mint a kisebb kötési energiák oldalán. A háttérhez a szilárd anyagon belüli rugalmatlan ütközések miatt energiaveszteséget szenvedett fotoelektronok járulnak, melyek a lefékeződés ellenére még eljutnak a detektorba és ott jelet váltanak ki. A háttérjelet indukáló kölcsönhatások két csoportra oszthatók. Az egyik eset, mikor elektron-fonon kölcsönhatás jön létre, ekkor a kristályrácsot alkotó atomok egységes rezgési frekvenciájának módosítására fordítódó energia (fonon) csökkenti a fotoelektron kinetikus energiáját. Másik esetben elektron-elektron kölcsönhatás felelős az energiadeficitért, mikor a mozgási energia egy vegyértékhéjon helyet foglaló elektron gerjesztésére fordítódik.

\subsection{XP spektrumok kiértékelésének lépései}

Minden ismeretlen anyag XPS segítségével végrehajtott analízisének első lépése egy áttekintő spektrum felvételével kezdődött. Ez alatt egy viszonylag nagy lépésközzel $(0,5 \mathrm{eV})$ felvett spektrumot kell érteni, mely felöleli a gerjesztő röntgensugárzás által meghatározott energiatartományt ( $\mathrm{Al} \mathrm{K} \mathrm{K}_{\alpha}$ : 0-1350 eV, $\mathrm{Mg} \mathrm{K}_{\alpha}$ : 0-1200 eV). Ennek birtokában képet kapunk arról, hogy mely elemek fordulnak elő a vizsgált szilárd anyagban. Ezt követôen kiválasztottuk a minket érdeklő komponensek legintenzívebb fotocsúcsát, egy tartományt jelöltünk ki számukra külön-külön, melyeken belül nagyobb felbontású (lépésköz: 0,025 eV) spektrumokat vettünk fel egymás után többször is, ezzel javítva a jel/zaj viszonyt.

Mivel a felvett spektrumon a csúcsok helyét az adott minta töltődése is befolyásolja - ami szigetelők esetén a leginkább számottevő -, ezért ennek hozzájárulásától mentesíteni kell a mért jelet. Ezt kalibrációval érhetjük el, melynek lényege, hogy egy ismert kötési energiájú referenciacsúcs segítségével korrigáljuk az energiaskálát. A szén szennyezésként szinte valamennyi mintában előfordul. A kalibráció céljára gyakran használt referencia a szén $\mathrm{C}$ 
1s vonala $(285,1 \mathrm{eV})$, ezen kívül használható más elem jele is, melynek pozíciójára nézve megfelelő irodalmi érték birtokában vagyunk. A kalibráció után a nem monokromatikus gerjesztő röntgensugárzás következtében megjelenő szatellit csúcsokat szoftver segítségével el kell távolítani.

A rögzített fotoelektron csúcsok további analízise során egy tartományt kell kijelölni, melyben meg kell adni a használni kívánt háttér típusát is. A szoftver ezt követôen a spektrum pontjait felhasználva, választásunknak megfelelő matematikai algoritmus alapján elvégzi a háttér illesztését. Itt is több opció kínálkozik, mi az esetek döntô hányadában Shirley és az egyszerű lineáris háttereket részesítettük előnybe. Utóbbi esetben a kijelölt tartomány kezdő- és végpontjának felhasználásával megrajzolt egyenes írja le a háttérgörbét. A Shirley algoritmus a csúcs alatti területek figyelembe vételén alapuló iteratív háttérintenzitás maghatározás. Adott minta csúcssorozatának kiértékelése során törekedtünk arra, hogy minden esetben ugyanazt a hátteret használjuk, mert ennek változtatása jelentős eltéréseket eredményezhet már a sorozaton belül is. A tartomány kijelölésekor meg kell adni, hogy melyik elemtôl származik a kérdéses csúcs, így a szoftver automatikusan betölti a megfelelô relatív érzékenységi faktort, amely az összetétel meghatározásakor nélkülözhetetlen paraméter.

Az XP spektrumok kiértékelésének egyik leglényegesebb momentuma a csúcsfelbontás (dekonvolúció), mikor is a mért jelalakot szintetikus, matematikai függvények segítségével igyekszünk reprodukálni. Komplex spektrumok esetén a csúcsfelbontás elvégzéséhez Gauss és Lorentz szorzat- vagy összegfüggvényeket használtunk, ahol a két típus arányát mi adtuk meg. A csúcs alatti terület meghatározásának szempontjából azért előnyös ezen függvények használata, mivel improprius integráljuk értéke véges. Olyan elemek, melyek esetén az egyelektronos gerjesztések nagyobb valószínúséggel játszódhatnak le a vegyértéksávban, gyakran produkálnak a nagyobb kötési energiájú oldalon hosszan elnyúló, aszimmetrikus spektrumot. Ilyen csúcsok illesztése aszimmetrikus lefutású (Gauss, Lorentz, illetve ezek kombinációja) függvények segítségével könnyen elvégezhetô.

Több komponens illesztésekor azok intenzitás arányának, pozíciójának, félértékszélességének meghatározásához kényelmes megoldást jelent a szoftverbe épített eljárás, mely minimalizálni igyekszik a burkológörbe és az illesztendő csúcs közötti eltérést. A kapott eredmény azonban gyakran irreális eredményre vezet, ezért bizonyos megkötésekkel élve az illesztés optimalizálható. A leggyakrabban alkalmazott restrikció, hogy egy csúcson belül a komponensek félértékszélességének meg kellett egyezni. Egy spektrumra rátekintve, annak aszimmetria viszonya alapján sok esetben jól látható volt az egyes összetevő́k hozzájárulása, így mindegyiknek definiálva egy intervallumot, melyen belül változhatott a csúcspozíciója, a valós képet húen tükrözô eredményt érhettünk el. Dublettek esetén csak az egyik felet illesztettük, leggyakrabban a nagyobb intenzitásút. A másik fél illesztése megkötések révén állt elô, ami az illesztés jóságának ellenôrzését is nagyban szolgálta. Ekkor két szempontot 
vettünk alapul: egyfelől a dublettek távolsága irodalomban fellelhetô érték, másrészt csúcs alatti területük arányát a pálya mellékkvantumszáma határozza meg. Az illesztés alkalmával feltételeztük, hogy ezek az értékek az egyes komponensek esetén is érvényesek.

\subsection{XPS és LEIS spektrumok felvétele során alkalmazott mérési paraméterek}

A spektrumok rögzítése egy SPECS gyártmányú röntgen fotoelektron spektrométerrel történt, mely kilenc channeltronnal rendelkező Phoibos 150 MCD9 típusú hemiszférikus analizátorral volt felszerelve. A mintából távozó elektronok belépő résre való fókuszálását speciális elektronlencse rendszer végezte. XP spektrumok felvétele során az analizátort FAT üzemmódban múködtettük, a pass energy-t 20 eV-ra állítottuk be. Az elektronsokszorozó egy csatornáján 100 ms-ig gyújtöttuik a beütéseket és a jel/zaj viszony javítása érdekében egy spektrumot 5-10-szeri futtatással vettünk fel.

Az analízis kamrában a mért nyomás minden esetben kisebb volt mint $10^{-8}$ mbar, melyet egy 500 1/s teljesítményú turbomolekuláris szivattyúval értünk el. A mintafogadó zsilipben és a nagynyomású cellában a vákuumot egy-egy 60 literes, szintén turbomolekuláris pumpa biztosította. Ezeknek a pumpáknak a múködéséhez szükséges elővákuum előállításáról bolygóspirál szivattyúk gondoskodtak, melyek múködése nem igényelt olajat, ami potenciális szennyezőforrást jelentett volna mintáinkra nézve. A készülék különböző, egymástól szeparált térrészeiben a nyomást egy-egy Bayard-Alpert típusú mérőfejjel mértük.

Röntgenforrásként a SPECS által gyártott XR50 típusú, kétanódos rendszert használtuk, melynek $\mathrm{Mg} \mathrm{K}_{\alpha}(\mathrm{E}=1253,6 \mathrm{eV})$ és $\mathrm{Al} \mathrm{K}_{\alpha}(\mathrm{E}=1486,6 \mathrm{eV})$, nem monokromatikus sugárzását használtuk. A röntgenágyú teljesítménye 150 Watt $(12,5 \mathrm{kV}, 12 \mathrm{~mA})$ értékre volt beállítva.

A katalízis kamrában úgynevezett elektronbombázásos fútést alkalmaztunk, tehát a szükséges hốt körülbelül $1000 \mathrm{~V}$ potenciálkülönbséggel felgyorsított elektronoknak a mintatartó lemezbe való becsapódásakor és lefékezésekor hő formájában felszabaduló kinetikus energia adta. A katalízis kamra túlmelegedését és a szerkezeti anyagok szublimálását megelőzendő, a katalízis kamra harang alakú felső része és a mintatartót illetve fútőszálat magában hordozó alsó része közötti viton tömítés hútése a turbomolekuláris szivattyúk és a röntgenágyú hőelvezetéséért felelős körhöz volt csatlakoztatva. A fütés szabályozásához egy Euroterm 2208-as szabályozót használtunk.

A LEIS mérésekhez szükséges kis energiájú ionokat egy SPECS IQE 12/38 típusú ionforrás szolgáltatta, kinetikus energiájuk méréséhez az analizátort FRR módban üzemeltettük. Az alkalmazott $\mathrm{He}^{+}$ionok gyorsításához $800 \mathrm{~V}$ potenciálkülönbséget alkalmaztunk, ami nem okozott felületmódosulást a vizsgált szilárd mintákon. Az ionok ütközés előtti impulzusvektora és a minta felületi normálisa által bezárt szög $55^{\circ}$ volt. 
A spektrumok felvételéhez a SpecsLab 2.2-t, kiértékelésükhöz a Casa Software Ltd által fejlesztett CasaXPS szoftvereket használtuk. A mérési eredmények ábrázolása, bemutatása az Origin 8.0 verziójának segítségével történt. 


\section{5. fejezet}

\section{Eredmények}

\section{1. $\quad \mathrm{TiO}_{2}$ nanoszálak és nanocsövek termikus kezelése és XPS vizsgálata}

A titanát nanoszálak és nanocsövek az egydimenziós nanostruktúrált anyagok csoportjába tartoznak. Nanocsövek esetén olyan belül üreges, mindkét végén nyitott szálakról beszélünk, melyek külsô átmérője 7-10 nm, míg belső átmérője $5 \mathrm{~nm}$, szerkezetüket tekintve 4-6 rétegből álló, többfalú, spirális keresztmetszetú struktúrák. Nanoszálaknál már nem marad meg az üreges felépítés, átmérőjük 45-110 nm, hosszuk 1,8 és $5 \mu \mathrm{m}$ között változik. Az általunk vizsgált anyagokat alkáli hidrotermális módszerrel állították elő anatázból [73, 121]. A szintézis alkalmával 50 g titán(IV)-oxidot (Degussa P25) 1000 ml 10 M koncentációjú nátrium-hidroxid oldathoz adagoltak és addig kevertettek, amíg homogén, fehér színú keveréket nem kaptak. Az így nyert oldatot teflonbéléssel ellátott, forgó autoklávba (a percenkénti fordulatszám nanocső szintézisekor 3-ra , nanoszálnál 28-ra volt állítva) helyezték, ahol azt nanocső esetén $428 \mathrm{~K}$, ha a cél nanoszál elóállítása volt, akkor $458 \mathrm{~K}$ hőmérsékleten tartották. A szobahômérsékletre hútött terméket ezt követôen leszûrték, majd desztillált vízzel addig mosták, míg pH-ja 7 körüli értékre csökkent. Ezt követően 0,1 M HCl oldat felhasználásával protonált állapotú titanátot állítottak elő, majd utolsó lépésben 303 K-en levegôn szárították a terméket. XPS méréseink arról tanúskodtak, hogy a rendelkezésünkre bocsátott minták tartalmaztak szennyező elemeket, ezért a nátrium mellett kálium, magnézium, kalcium jelenlétével is számolni kellet. Alapos mosásnak köszönhetôen a felületen kimutatható szennyező elemek mennyisége $1 \%$ alá csökkenthetô.

A legfontosabb paraméter, ami meghatározza, hogy a reakciótermék összetételében a nanocső vagy a nanoszál mennyisége domináljon, az autoklávban alkalmazott szintézis idő. Csövek esetén ez 20-24 órát vesz igénybe, a szálak képződéséhez pedig 60-70 órát kell várni. Az előbb részletezett reakciókörülmények megvalósulásakor a titanát nanoobjektumok csö- 
ves szerkezete egy magasabb ponton elhelyezkedő lokális minimumot jelöl ki a potenciális energia felületen, mint a szálas struktúra. A két forma szerkezetéből fakadóan a nanocsövek fajlagos felülete több mint négyszer nagyobb, melyet $\mathrm{N}_{2}$ adszorpciós mérések segítségével állapítottak meg [73].

Érdeklődésünk kereszttüzében a titanát nanostruktúrákban, a hőmérséklet növelés hatására bekövetkező módosulások feltérképezése állt. Ezeket a méréseket 298-773 K tartományban végeztuik, inert atmoszférában. A 60 perces kezeléseket a katalízis kamrában hajtottuk végre, állandó $40 \mathrm{ml} /$ perc nitrogén áramban. XP spektrumot csak a minta lehútését és evakuálását követôen rögzítettünk, a következő hőmérsékletre való felfútéshez már friss, kezeletlen állapotú preparátumot használva.
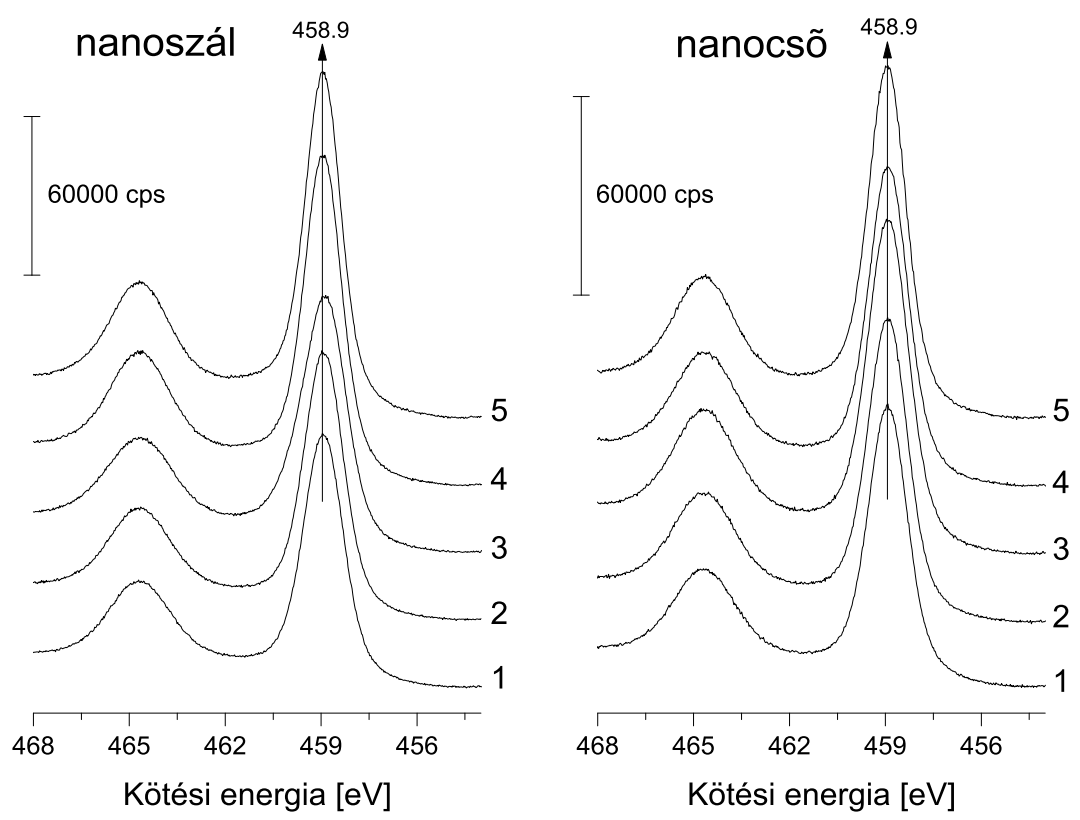

5.1. ábra. Ti 2p pálya kötési energiája 298 (1), 473 (2), 573 (3), 673 (4) és 773 (5) K hőmérsékletű hőkezelést követően

Az egyes hőkezelési fázisokban felvett Ti spektrumokat az 5.1. ábrán tüntettem fel. A Ti $2 \mathrm{p}_{3 / 2}$ maximumot választottuk referenciának, csúcspozícióját 458,9 eV kötési energiánál rögzítettük. Az így kapott spektrumokon a C 1s csúcs burkológörbéjének legintenzívebb komponense minden esetben $285,1 \mathrm{eV}$-nak adódott, ami a Ti $2 \mathrm{p}_{3 / 2}$ referenciaként való alkalmazhatóságát támasztotta alá. Láthatóan a Ti $2 p$ dublettek minden esetben szimmetrikus alakúak, ami a felületi réteg megfelelő rácspontjaiban található titán-ionok - XPS kimutatási határán belül - egységes fizikai és kémiai tulajdonságából fakad. Ez a megállapítás viszont az oxigénre már nem érvényes, mint az az $\mathrm{O}$ 1s aszimmetrikus spektrumokról egyértelmúen leolvasható (5.2. ábra). A csúcsfelbontás irodalomból származó adatok felhasználával tör- 
tént [109]. Ennek során a spektrum lefutásának figyelembe vételével, minimális számú komponenst generáltunk, melyek helyét az irodalmi értékeknek megfelelően rögzítettünk úgy, hogy minden esetben csak egy-két tized elektronvolt elmozdulást engedtünk meg. Továbbá egy spektrumon belül minden összetevő félértékszélességét azonosnak vettünk.

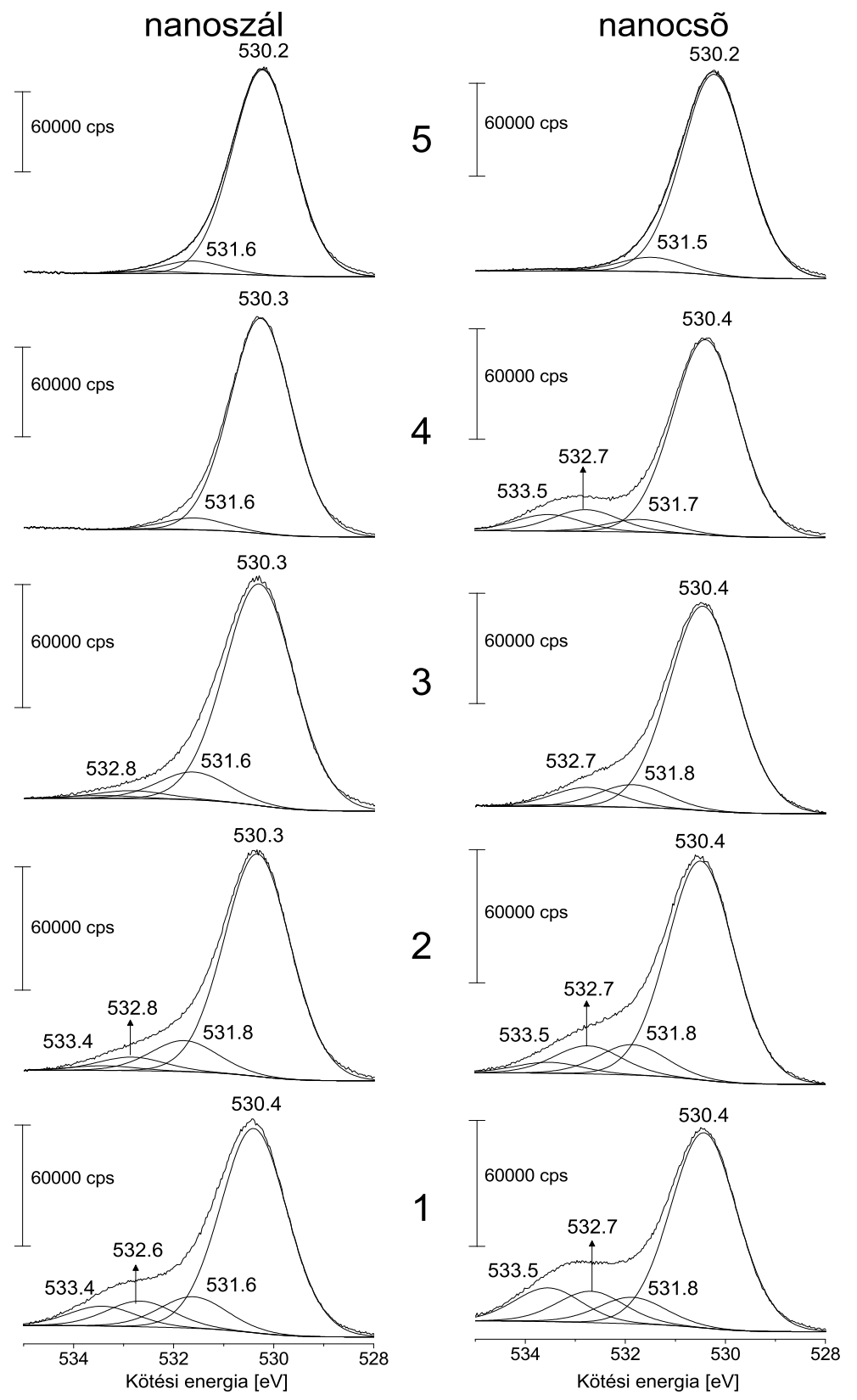

5.2. ábra. Csúcsfelbontással kapott O 1s pályák kötési energia értékei 298 (1), 473 (2), 573 (3), 673 (4) és 773 (5) K hőmérsékletú hőkezelést követően

A csúcsfelbontást ezen kikötések figyelembe vételével hajtottuk végre. A $\mathrm{TiO}_{2}$ minták felületén 298 K-en négyféle oxigén jelenlétét erôsítették meg méréseink, melyek kötési energiái 533,4-533,5, 532,6-532,7, 531,5-531,8 és 530,2 eV-nak adódtak. Ezek közül a legnagyobb intenzitású csúcs 530,4 eV kötési energiával jellemezhetô, úgynevezett háromfo- 
gású oxigén, ami megfelel a $\mathrm{TiO}_{2}$ felülethez közel helyet foglaló, tömbfázisra jellemző $\mathrm{O}^{2-}$ atomoknak. A többi komponens felületre jellemző oxigénféleségek jelenlétéből adódott.

531,5 - 531,8 eV-nál található a kétfogású oxigének jele, melyek két szomszédos titán atom között hoznak létre hídszerú kötést a felületen. Az egyetlen titánhoz kapcsolódó oxigének 532,5 - 532,8 eV csúcsmaximummal rendelkező összetevővel járulnak hozzá a spektrumokhoz. Az 533,4 eV-os jel a felületen adszorbeálódott víztől származik. Ezekből a megfigyelésekből is kitúnik az a tendencia, hogy minél kevesebb titán atom található adott oxigén atom környezetében, annál nagyobb a kötési energiája az illető oxigénnek.

Nanoszál esetében $473 \mathrm{~K}$ felett, a tömbfázisra jellemző oxigén kivételével, mindegyik típus jelintenzitása csökkent, a felületi víz $573 \mathrm{~K}$ hőmérsékleten már kimutatható mennyiségben nincs jelen. $673 \mathrm{~K}$ felett pedig csak a hídkötésú felületi oxigén jelenléte mutatható ki a fôkomponens mellett, ami a felületi struktúra jelentős átalakulásáról ad számot.

A nanocső felületének módosulása, a nanoszállal összevetve, kisebb mértékú változásokat tükröz 298 - 573 K tartományban. Az egyfogású oxigének jele kevésbé csökken, a két oxigénforma aránya közel 1:1 marad, míg az adszorbeált víz jelenlétével itt sem kell számolni $473 \mathrm{~K}$ felett. Ha viszont $673 \mathrm{~K}$ hőmérsékletre fütjük fel a mintát, 533,5 eV-nál ismét megjelenik egy komponens. További eltérés a nanoszálhoz képest, hogy ezen termikus fázisban sem tûnik el az egyetlen titánhoz kapcsolódó oxigén jele. Az újra megjelenő csúcs értelmezésére több lehetôség is kínálkozik. Egyfelől köthetô a nanocső belsô felületén adszorbeálódott vízhez, mely a csövek falának sérülése által válik láthatóvá. További lehetséges magyarázatként jöhet szóba az az elképzelés, mely a nanostruktúrák átkristályosodása alkalmával, a felületi hidroxil-csoportok és hidrogén között lejátszódó reakciót kísérő vízképződést valószínúsíti. Ezt támasztja alá az XP spektrumon tapasztalható 531,7 eV kötési energiájú összetevő intenzitásának csökkenése. Ezen a hőmérsékleten megjelenô új komponens a C 1s spektrumon formiát-csoportok feltúnését is jelezheti, melyre mint újabb megfontolásra érdemes magyarázatként kell tekintenünk. $773 \mathrm{~K}$-en a nanocső és a nanoszál felületi struktúrájában lényeges különbség nem állapítható meg.

A nanostruktúrák termikus kezelése során bekövetkező felületi változások pontos értelmezéséhez az XPS önmagában nem elegendő, ezért további vizsgálati módszerek által szolgáltatott információkra is támaszkodtunk, mint az XRD, a TEM, és a Raman spektroszkópia. Ezek közül az XRD eredményeit említeném meg, mely a fázisátalakulás nyomon követését teszi lehetővé. Erre alapozva kijelenthetjük, hogy a termodinamikailag stabilabb nanoszálak 850 K-ig megôrzik szerkezetüket, míg a nanocsöveknél 600 K körül indulnak el az átkristályosodási folyamatok. A kristályosodás során mindkét esetben anatáz fázis jelenik meg [122].

Ezek a mérési eredmények rámutatnak arra, hogy lényeges eltérések vannak a szóban forgó két nanostruktúrált objektum felületi szerkezetét illetően. A különbségek figyelembe 
vétele hozzájárulhat a heterogén katalitikus reakcióikban mutatkozó eltérések értelmezéséhez, ahol a lejátszódó reakciók szempontjából a felület savas vagy bázikus karakterére meghatározó szerep hárul.

\section{2. $\quad \mathrm{TiO}_{2}$ nanoszálak és nanocsövek módosítása fémekkel}

A heterogén katalízisben gyakran alkalmaznak oxidhordozóra felvitt fémeket. Mára már elfogadott az az álláspont, hogy az oxidoknak a szerepe túlmutat azon, hogy pusztán csak hordozóként tekintsünk rájuk. A felvitt fém vagy fémek és az oxidhordozó között bonyolult kölcsönhatások alakulhatnak ki, melyek döntően befolyásolják az adott rendszer katalitikus sajátosságait. Ezen mélyebb összefüggések pontosabb megismerése kulcsszerepet játszik a szilárd anyagok felületén lejátszódó reakciók kutatásában. A titanátok szerepe ebbôl a szempontból igen érdekes, mivel könnyen kialakulhatnak hibahelyek a felületükön, melyek különleges szerepet játszanak a fém-hordozó kölcsönhatások tekintetében. A kutatások során további mozgásterünket szinesíti ha nem csak egy fémet, hanem kétfémes rendszereket hozunk létre, és/vagy ha sikerül a fémrészecskéket nagy diszperzitású formában előállítani és stabilizálni. A nagy diszperzitásfokú nemesfémek előállításának jelentôsége abban rejlik, hogy ilyen formában katalitikus aktivitással rendelkeznek, szemben a tömbfázisú, inert formájukkal. Vizsgálataink az arany, ródium és kobalt tartalmú egy- illetve kétfémes rendszerek pontosabb megismerését szolgálták, ahol a hordozó szerepét a nanostrukturált titanátok játszották.

\subsubsection{Ródiummal módosított $\mathrm{TiO}_{2}$ nanoszálak és nanocsövek XPS vizs- gálata}

A ródiumot impregnálással, $\mathrm{RhCl}_{3}$ oldat felhasználásával vitték fel a hordozók felületére, a hordozó össztömeg 1 \%-ának megfelelố mennyiségben. Majd a szuszpenzió 3 órás, 383 K hőmérsékleten végzett szárítását egy 573 K hőmérsékletű hidrogén atmoszférás kezelés követett.

A kiindulási állapotú mintákon $300{ }^{\circ} \mathrm{C}$ hômérsékleten, 30 perces oxigénes, majd $300{ }^{\circ} \mathrm{C}$ -on, 60 perces hidrogénes kezelést hajtottunk végre, mindkét esetben XP spektrumokat is felvettünk.

A Rh 3d XP spektrumok illesztésekor figyelembe kell venni, hogy már az egykomponensû csúcsok is aszimmetrikus lefutásúak, ami a a Fermi-szinten lévő elektronok és a fotoelektron kölcsönhatásának következtében jön létre. Ezért a csúcsfelbontás során szintén aszimmetrikus függvényekkel kellett az illesztéseket elvégezni, egyszerú Gauss-Lorenzt 
összegfüggvények nem alkalmazhatóak ebben az esetben.

nanoszál
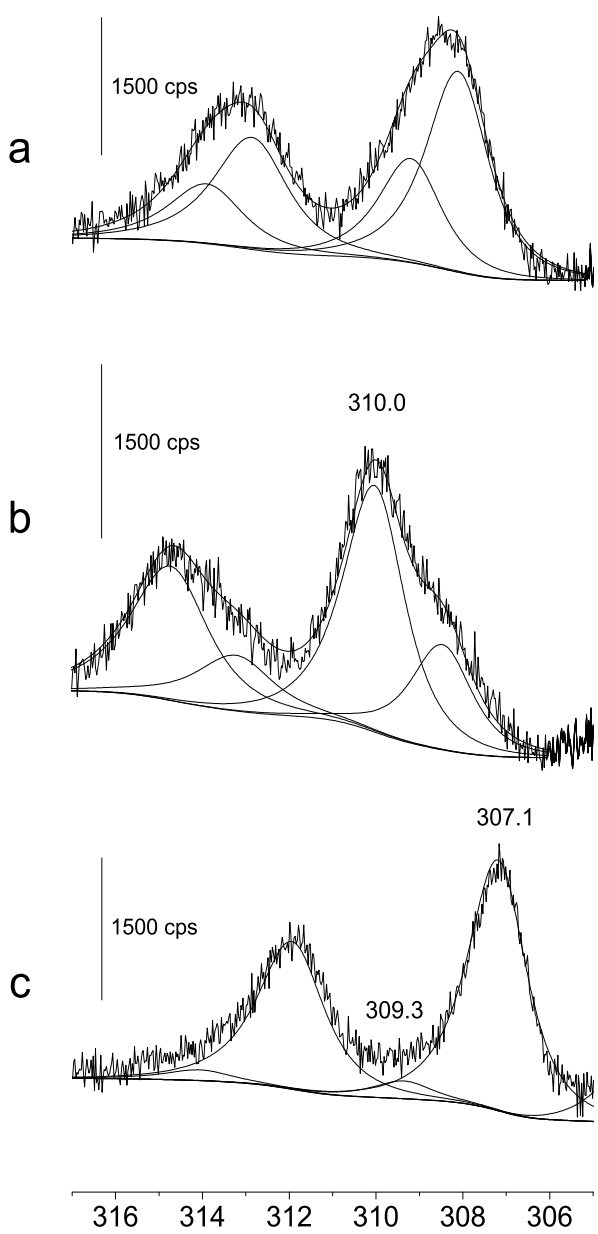

Kötési energia [eV] nanocsõ
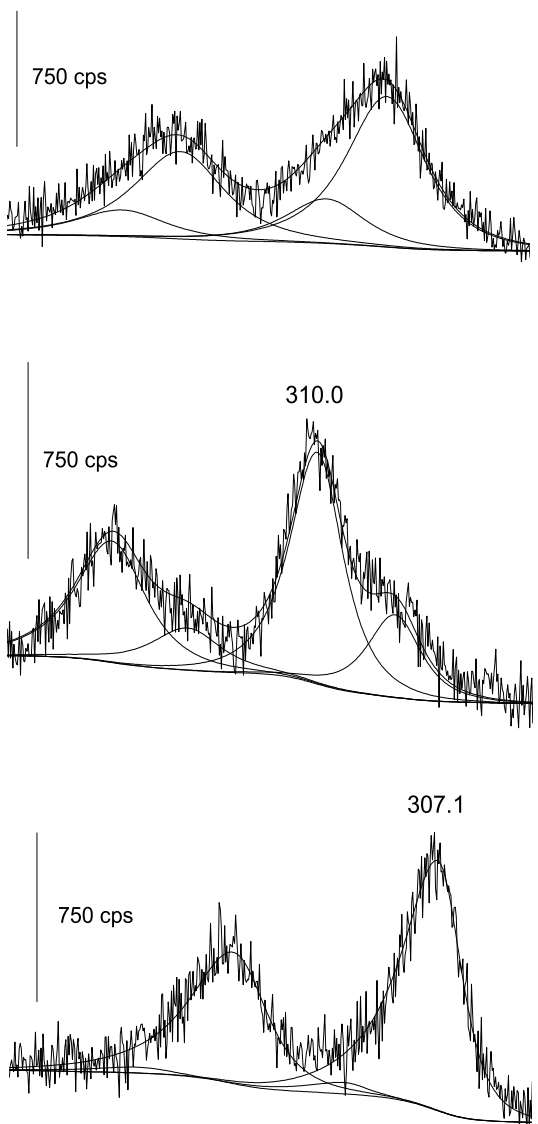

$\begin{array}{llllll}316 & 314 & 312 & 310 & 308 & 306\end{array}$

Kötési energia [eV]

5.3. ábra. Ródium tartalmú nanostruktúrált titanátok Rh 3d XP spektrumai kiindulási állapotban (a), oxidációt (b) és redukciót (c) követően

A ródiummal módosított nanoszálak és nanocsövek különböző kezelések után felvett XP spektrumait az 5.3. ábrán tüntettem fel. Az oxidációt 573 K hőmérsékleten hajtottuk végre, melynek során hasonló lefutású spektrumokat kaptunk mindkét esetben. Az aszimmetrikus jelalak arról tanúskodik, hogy itt még két különböző vegyértékú ródium van jelen a felületen. A csúcsfelbontással nyert legintenzívebb komponens pozíciója 310,0eV-nál látható, ami megfelel a hármas oxidációs állapotú ródiumnak. Ezt követte a hidrogénnel végrehajtott redukciós lépés szintén $573 \mathrm{~K}$ hőmérsékleten. Ennek eredménye a fém állapotú ródium, a spektrum nagyobb kötési energiájú oldalán vállak nem láthatók, vagyis magasabb oxidációs állapotban nem maradt vissza fém. A Rh $3 \mathrm{~d}_{5 / 2}$ csúcsmaximuma 307,1 eV energiánál van 
mindkét hordozón. Nanocső esetén az illesztés egy komponenssel is elvégezhetô volt, szemben a nanoszállal, ahol pontosabb eredményt kaptunk, ha 309,3 eV-nál is feltételeztünk egy összetevôt. Ez az összetevő nem köthető oxidált ródiumhoz, mivel redukált állapotú mintáról van szó, illetve az oxidált fázisban sem láttunk 309,3 eV-os komponenst. A nagyobb kötési energiájú jelet a nagy diszperzitású, kis részecskeméretú ródiumrészecskék megjelenésével magyarázhatjuk. Ennek értelmezéséhez azt kell szem előtt tartani, hogy a fémklaszterek méretének csökkenése a mért kötési energiák növekedését vonja maga után. Ugyanis a részecskeméret csökkenésével párhuzamosan egyre kisebb szerepet játszik a szomszédos atomok vegyértékelektronjai által biztosított extra-atomi relaxációs hatás (screening effect). Így a mért kötési energia egyre inkább az izolált atomokra vonatkozó értékkel egyezik meg. Ilyen kis részecskeméretû ródiumra utaló jelet a nanocsöveken nem tapasztaltunk, ami tovább erősíti azon kijelentésünket, miszerint a kétféle oxidhordozó eltérő felületi struktúráltsággal bír. Ez játszhat szerepet abban, hogy a nanoszál felületén olyan kölcsönhatások alakulhatnak ki, melyek a nagyobb diszperzitású részecskéket stabilizálni képesek még az általunk vizsgált magas hőmérsékleten is, míg a nanocsövek esetén ezzel a hatással nem számolhatunk.
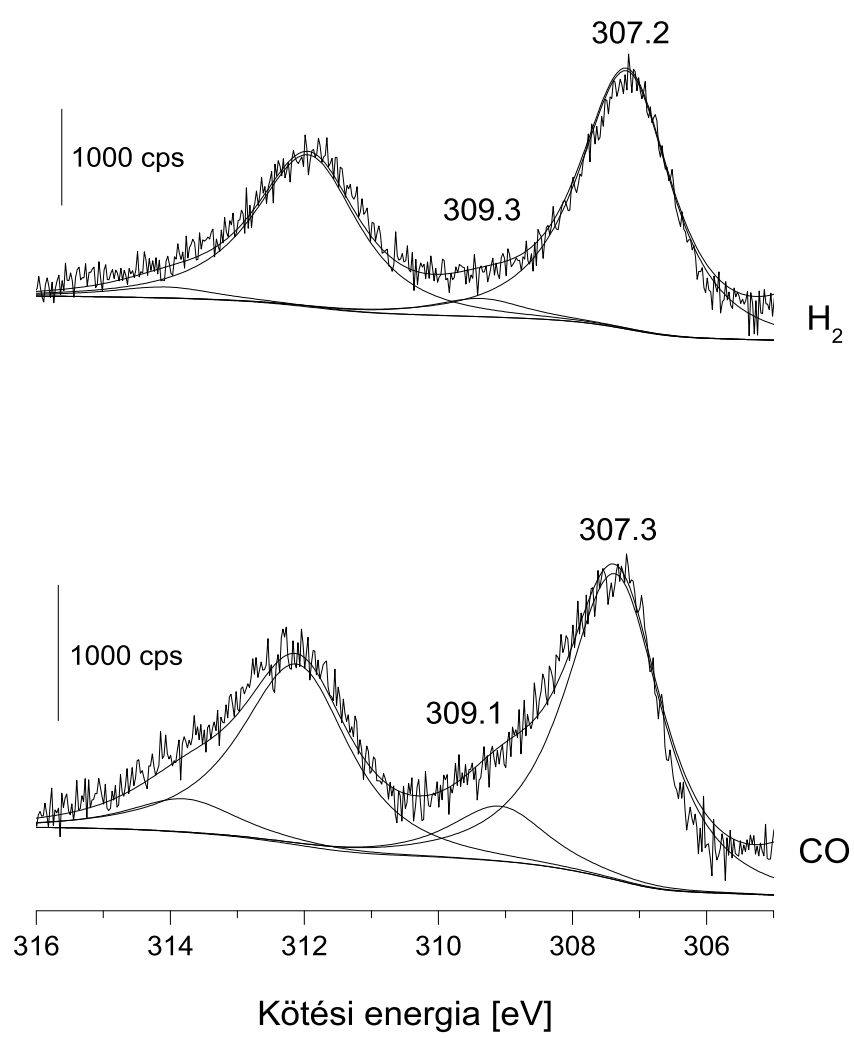

5.4. ábra. Ródium tartalmú nanoszál minták Rh 3d XP spektrumai redukciót (felül) és CO adszorpciót (alul) követôen, $\mathrm{P}_{C O}=1$ bar

Mint ismeretes a szén-monoxid és a ródium között a részecskemérettől függő kölcsönha- 
tások jönnek létre [124]. Közepes méretú részecskékkel történő kölcsönhatás lineáris illetve híd szerkezetű struktúrák kialakulását okozzák, ahol a szén egy- illetve két ródiumhoz kapcsolódik. Azonban csak megfelelően kis részecskeméret mellett jöhet létre az úgynevezett iker struktúra, mikor egy ródiumhoz két szén-monoxid molekula kötődik egyidejúleg. Ha a szén-monoxid képes a ródium részecskék diszperzitásfokát növelni, akkor ennek megfelelően az XP spektrumokon a 309,3 eV energiájú csúcs jelintenzitásának növekedését feltételezhetjük. Ennek érdekében a redukált mintán 60 percen keresztül szén-monoxidot adszorbeáltattunk, majd újra spektrumot vettünk fel. Az 5.4. ábrán látszik, hogy a kisméretû részecskék jelenlétének tulajdonított nagyobb kötési energiájú tag intenzitása növekedett. Az eredmény alátámaszthatja azt a feltételezést, hogy a szén-monoxid elősegíti a ródiumklaszterek szétesését, így a nagyobb kötési energia tartományban detektált csúcs összefüggésben állhat a részecskeméret csökkenésével. Ezen kívül nincs kizárva annak az eshetôsége sem, hogy a CO adszorpció hatására parciális pozitív töltésú Rh jelenlétét detektáljuk, miközben részecskeméretbeli változások nem játszódnak le.

A
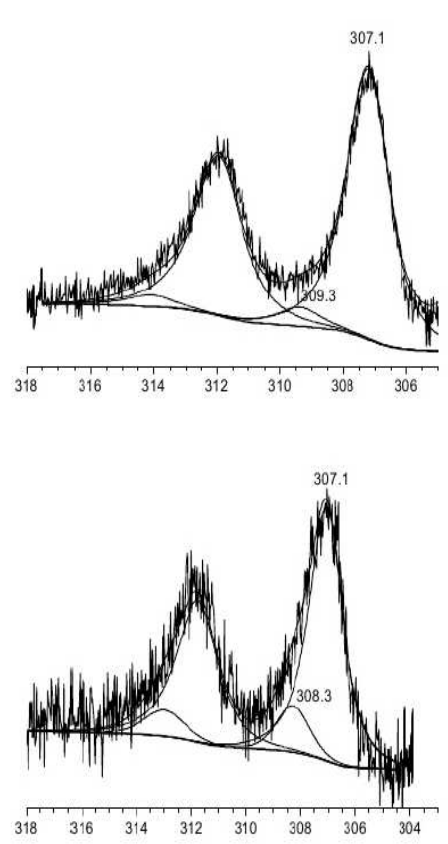

B
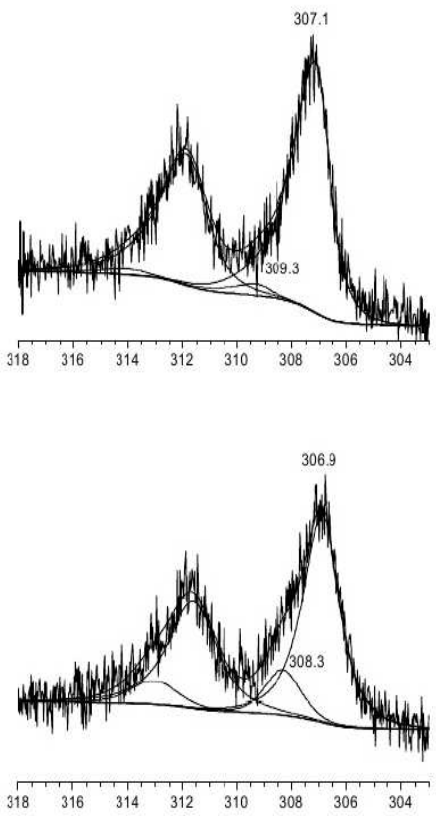

Kötési energia [eV]

5.5. ábra. $\mathrm{Rh} 3 \mathrm{~d}$ spektrumok fémmel adalékolt $\mathrm{TiO}_{2}$ nanoszál (A) és nanocsô (B) esetén. Felül: $1 \%$, alul: $2 \% \mathrm{Rh}$ tartalmú minták

További vizsgálatokat végeztünk különböző nemesfémtartalmú mintákkal. Az egyik ródiumra nézve $1 \%$-os, a másik pedig $2 \%$-os volt. Mindkét mintán az előzóekben már részletezett módon hajtottuk végre a kezeléseket, majd a redukció után spektrumokat vettünk fel, melyeket összefoglalóan az 5.5. ábrán mutatok be. Ennek segítségével összehasonlíthatjuk a korábban már ismertetett csúcsokat a 2 \% fémtartalmú esetekkel. Látható, hogy a ródium 
mennyiségének növelésével a 309,3 eV kötési energiájú összetevő 308,3eV-ra csökken mind a nanoszál, mind a nanocső esetén. Ez magyarázható azzal, hogy a fém mennyiségének növelésével csökken a kis méretű klaszterek kialakulásának valószínúsége, ami a spektrumon a kisebb kötési energiák felé tolja el a csúcsmaximumok értékét.

Titanát nanostruktúrák felületén a kisméretú ródium klaszterek stabilizálása létrejöhet a közöttük kialakuló elektromos kölcsönhatások eredőjeként is. A hordozó előállítási körülményei kedveznek a hibahelyek kialakulásának, melyek nukleációs pontokként funkcionálhatnak a Rh részecskék formálódása során, miközben elektronáramlás is bekövetkezhet a két partner között.

\subsubsection{Arannyal módosított $\mathrm{TiO}_{2}$ nanoszálak és nanocsövek XPS vizs- gálata}

A titanát nanostruktúrák felületére ez esetben is impregnálás útján történt a fém felvitele, számított mennyiségú $\mathrm{HAuCl}_{4}$ oldat felhasználásával. A kapott terméket $383 \mathrm{~K}$ hőmérsékleten szárították 3 órán keresztül, amit egy 573 K-es hidrogén atmoszférában végrehajtott utókezelésnek is alávetettek. Az így előállított minták aranytartalma $1 \%$ volt.

A spektrumfelvételt minden vizsgált mintán egy 30 perces, $300{ }^{\circ} \mathrm{C}$-os oxidációt, majd egy 60 perces $300{ }^{\circ} \mathrm{C}$-os hidrogénes redukciót követően végeztünk. A kezelt minták lehútése a kezelőkamrában nitrogén atmoszférában történt.

Az 5.6. ábra bal oldali oszlopa mutatja be a nanoszálakon felvett Au 4f spektrumokat, a jobb oldali oszlop pedig a nanocsövekre vonatkozik. A kezeletlen mintákról felvett spektrumok két összetevőt tartalmaztak: egy 85,1 eV és egy 83,8 eV energiájú $4 f_{7 / 2}$ komponenst. Utóbbi érték a fém aranynak felel meg, amely a vákuum hatására elbomlott $\mathrm{AuCl}_{3}$-ból maradt vissza, utóbbi pedig az aranysóhoz köthetô. Oxidáció után a fém állapot arányának növekedése látható, mely lényegesen nagyobb mennyiségben van jelen a nanocsövek felületén, a kisebb intenzitású csúcs pedig az oxidált állapot kialakulásával magyarázható. A redukciót követôen azt lehet feltételezni, hogy a titanátok felületén csak fém arany található. Az erősen aszimmetrikus spektrumok felbontását követôen mindkét hordozón adódott egy csúcs 85,6 eV-nál, mely a nanoszálak esetén sokkal nagyobb csúcs alatti területtel rendelkezett. Mivel ez a komponens a redukciós fázis után jelent meg, ez kizárja az oxidált állapot létezését. Magyarázatként a nanoméretú klasztereknél megfigyelt jelenséget kell megemlíteni, hasonlóan ahhoz, amit a ródium tartalmú hordozók esetében is tapasztaltunk. Itt is ugyanarra a következtetésre jutunk, vagyis a nanoszál nemcsak a kialakuló nagy diszperzitású ródium, hanem az arany részecskéket is képes ezen állapotukban stabilizálni felületén. Ilyen hatást nem tapasztaltak korábban $\mathrm{TiO}_{2}$-on és $\mathrm{Al}_{2} \mathrm{O}_{3}$-on végzett vizsgálatok alkalmával, ahol az aranyat a mi esetünkkel azonos impregnálásos technikával vitték fel [123]. 
Az arannyal módosított titanát nanostruktúrák vizsgálata is arra az eredményre vezet, melyet a ródium esetén már megállapítottunk: a nanoszálak felülete hatékonyabban képes stabilizálni a nagydiszperzitású fémeket. A felületen megjelenő kisméretú fémrészecskék minden bizonnyal nem tekinthetők monodiszperz eloszlásúnak. A spektrumok csak arról adnak számot, hogy hozzávetôlegesen 1,5 - $5 \mathrm{~nm}$ méretú klaszterek is jelen vannak, melyek csúcspozíciójának meghatározása az XPS felbontóképessége miatt nem lehetséges, ebből fakadóan csak az eredő burkológörbe megállapítására nyílik lehetôség.

nanoszál

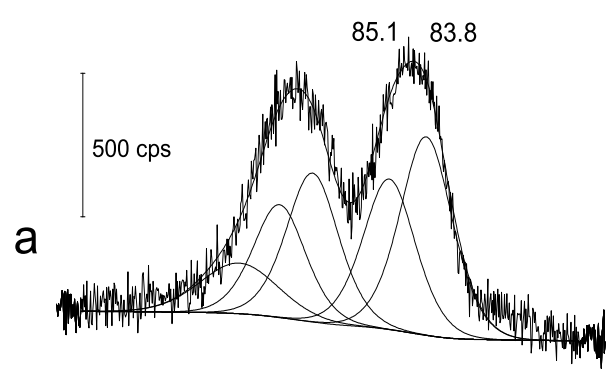

83.7
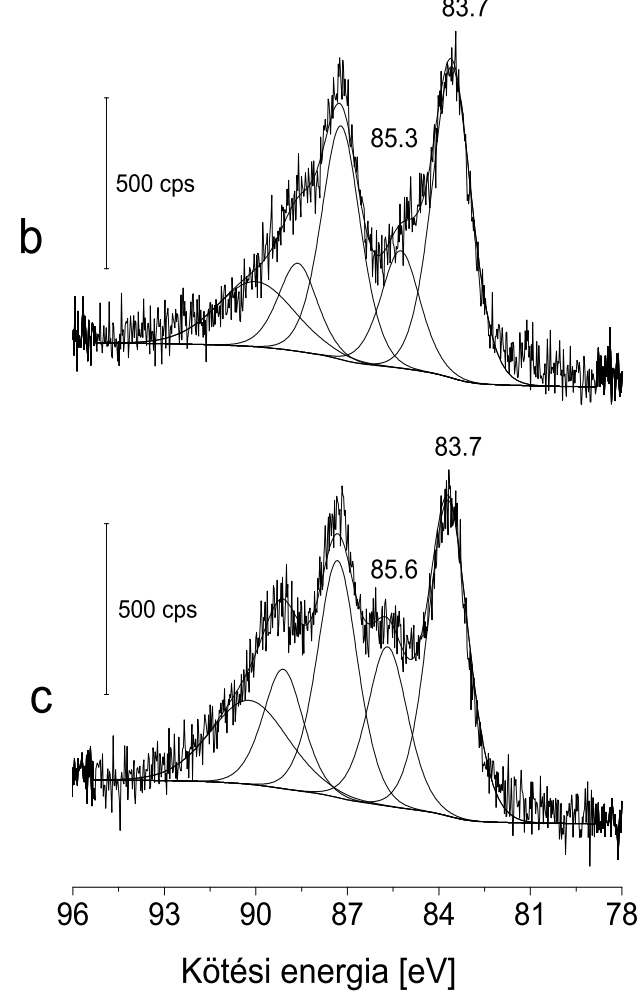

nanocsõ
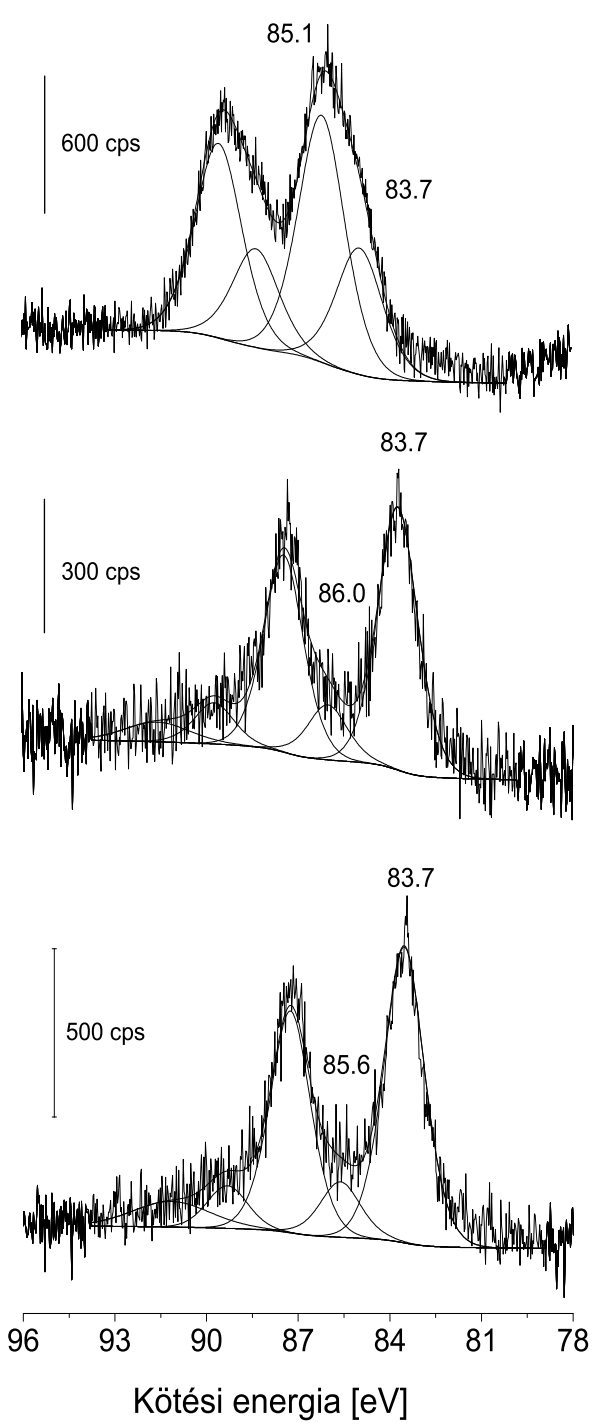

5.6. ábra. Nanostruktúrált titanát hordozóra felvitt arany 4f pályák XP spektrumai kiindulási állapotban (a), oxidációt (b) és redukciót (c) követôen 


\subsubsection{Arany-ródium kétfémes rendszerek XPS és LEIS vizsgálata}

Az előállítás az előző két esetben ismertetett lépésekkel megegyező módon történt, értelemszerúen $\mathrm{HAuCl}_{4}$ és $\mathrm{RhCl}_{3}$ oldatok felhasználásával. A kapott termékben a két fém 50 - 50 atom\% arányban volt jelen. A kezelés fázisai sem tértek el az egyfémes rendszereknél alkalmazottaktól, vagyis a 30 perces, $300{ }^{\circ} \mathrm{C}$-os oxidációt egy 60 perces, $300{ }^{\circ} \mathrm{C}$-os hidrogénes redukció követett, a szobahőmérsékletre való hútés során minden esetben nitrogén atmoszférát használtunk. Az eredmények ismertetése során ez esetben, ha külön nem történik erre utalás, csak a redukált mintákra érvényes megállapításokra fogunk szorítkozni.

nanoszál

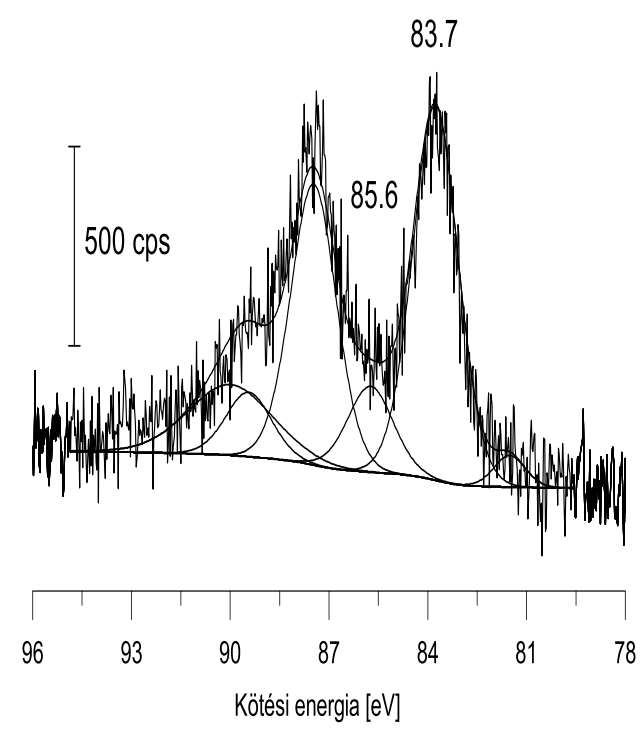

nanocsõ

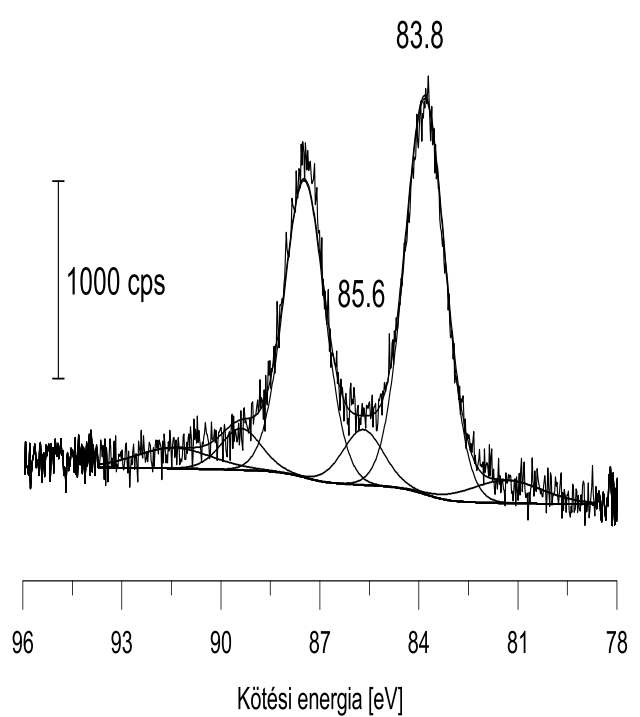

5.7. ábra. A redukált állapotú, arany és ródium tartalmú nanostruktúrált $\mathrm{TiO}_{2}$ felületrôl felvett Au 4f pályák XP spektrumai

A kétfémes nanoszálakról felvett arany spektrumok szemléltetésében az 5.7. ábra nyújt segítséget. Ha ez alapján összevetjük az egyfémes redukált mintán kapott arany 4 f spektrumot (5.6. (c) ábra) a kétfémes rendszer ugyancsak redukció után adódó spektrumával, láthatjuk, hogy ródium jelenlétében a 85,6 eV energiájú komponens intenzitása jelentôsen kisebbé válik. Ez viszont azt jelenti, hogy az 1,5-5 nm átmérőjú aranyrészecskék mennyisége lecsökken, de nem túnik el teljesen. Vagyis az arany és a ródium közötti kölcsönhatás eredményeként a kétfémes klaszter méretnövekedése következik be. A nanocsöveknél is tapasztalható diszperzitásnövekedés, mivel az arany tartalmú egyfémes mintákon a két összetevő (85,6 és 83,7 eV) intenzitásaránya 1/5, míg kétfémes rendszerben ez az érték 1/8-ra módosul.

A ródium 3d spektrumok (5.8. ábra) esetében is hasonló tapasztalatokat szúrhetünk le: a nagy diszperzitású fémrészecskékhez rendelt 309,2 eV-os komponens nélkül is jó illesztést 
kapunk, ami az aggregálódás valószínúségét erôsíti meg.

nanoszál

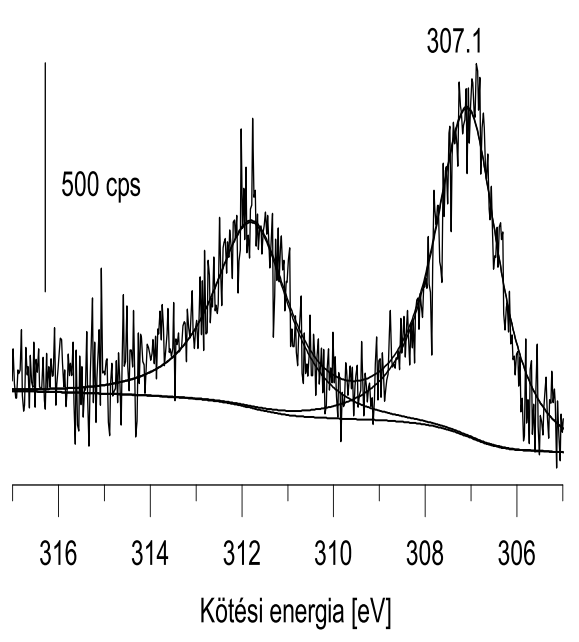

nanocsõ

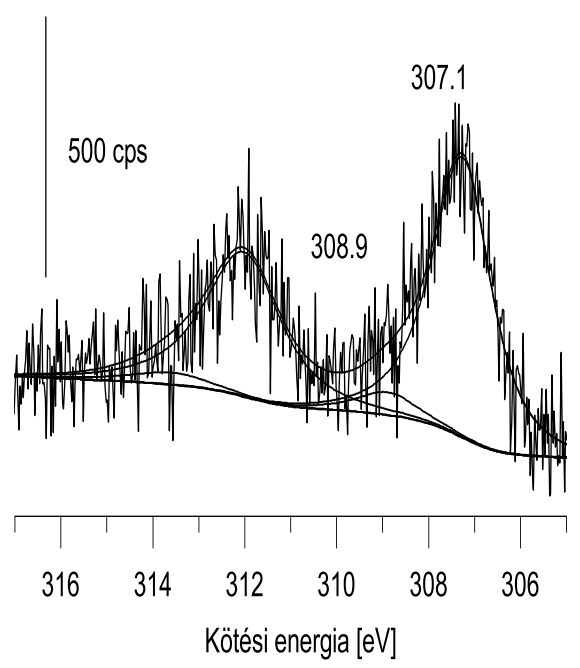

5.8. ábra. A redukált állapotú, arany és ródium tartalmú nanostruktúrált $\mathrm{TiO}_{2}$ felületrôl felvett $\mathrm{Rh} 3 \mathrm{~d}$ pályák XP spektrumai

További megválaszolásra váró kérdés annak tisztázása, hogy milyen a kialakuló aranyródium klaszter felületi atomösszetétele, ha a fémek közel 1:1 arányban vannak jelen. Korábban kimutatták, hogy az arany felületi diffúzió révén képes beborítani a ródium részecskéket [125]. Mivel itt egy spontán lejátszódó folyamatról van szó, ezért a termodinamikai értelmezéshez a szabadentalpia csökkenésérôl kell számot adni. Ismeretes, hogy a felületi szabadentalpia - az a reverzibilis munka, melyet állandó hőmérsékleten, állandó nyomáson, egységnyi felület létrehozásához be kell fektetni - arany esetén 1,626 J/m², míg ródiumnál $2,828 \mathrm{~J} / \mathrm{m}^{2}$. Ebből az követketkezik, hogy a felület összetételének kialakulásában az arany atomok fognak dominánsabb szerepet játszani. Ennek a kérdésnek a tisztázására a LEIS módszer kínálkozik a legkézenfekvőbb választásnak, mivel ezzel a legfelső atomréteg összetételérôl nyerhetünk információt. A klaszter belső szerkezetét pontosan nem ismerjük, de mivel tömb fázisban az arany és a ródium nem elegyedik egymással, ezért feltételezhetően mag-héj struktúra jön létre, ahol a belül helyet foglaló ródiumból álló magot borítja be az arany.

A LEIS mérésekhez 800 eV kinetikus energiájú hélium ionokat használtunk. Ilyen múködési paraméterek mellett az arany jele 753 eV- nál, a ródiumé 707 eV-nál jelentkezik (5.9. ábra). Az egyfémes titanát nanoszálakon semmi meglepót nem tapasztaltunk, vagyis csak az adott elemnek megfelelő szórási spektrumokat kaptunk. A kétfémes esetben viszont csak aranyat lehetett kimutatni, az egyfémes rendszerhez képest lényegesen nagyobb jelintenzitással, míg ródiumot nem detektáltunk. Ebből az a következtetés adódik, hogy az arany képes 
teljesen beborítani a felületen elhelyezkedő ródium részecskéket. Az intenzitásnövekedés pedig a felületi aranyatomok számának növekedése miatt következik be. Ez összhangban van a kétfémes hordozókról felvett XPS eredményekkel és megmagyarázza a 85,6eV-os csúcs $1 \%$ arany tartalmú mintákhoz viszonyított jelentôs intenzitáscsökkenését.

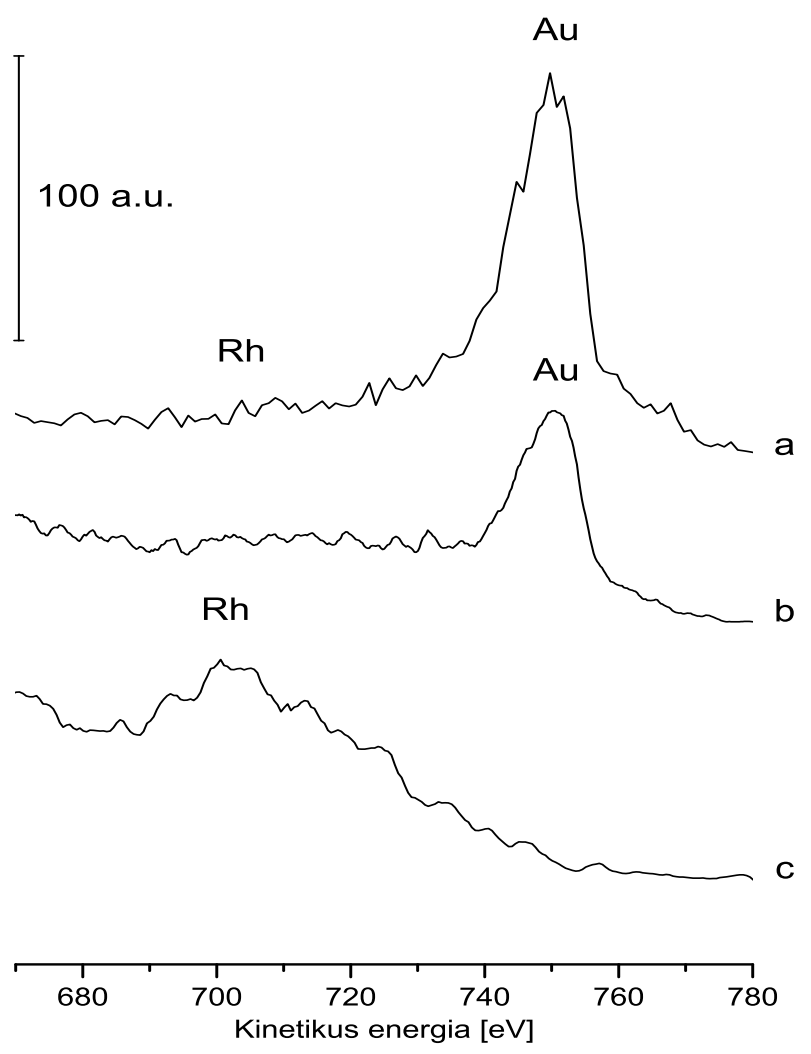

5.9. ábra. LEIS spektrumok a $0,5 \% \mathrm{Au}+0,5 \% \mathrm{Rh} / \mathrm{TiO}_{2}$ (a), az $1 \% \mathrm{Au} / \mathrm{TiO}_{2}$ (b) és az $1 \%$ $\mathrm{Rh} / \mathrm{TiO}_{2}$ mintákról

Az arany-ródium kétfémes rendszer tulajdonságainak mélyebb megismerése érdekében megvizsgáltuk, hogy a szén-monoxid adszorpció milyen hatást gyakorol a felület szerkezetére. Mivel az arannyal nem lép kölcsönhatásba a szén-monoxid, ezért a kétfémes esetben nem várnánk érdemi változást. Ezzel szemben IR mérések CO kötések jelenlétérôl számoltak be, vagyis kezelés hatására a mag-héj szerkezet átrendeződik és ródium atomok diffundálnak a klaszterek felületére [126]. Az 5.10. ábra bizonyítja, hogy az arany fizikai, kémiai állapotában nem következik be változás, ellenben a ródium spektrumon ismét megjelenik egy nagy kötési energiájú összetevő 308,9 eV energiánál. Ez utóbbi hatás feltételezhetően a ródiumrészecskék széteséséből adódik.

A kétfémes nanocsöveken, az Au 4f és a Rh 3d spektrumok alapján, kisebb a nanodiszperz részecskék részaránya, mint amit a nanoszálak esetén tapasztaltunk. Ez nem is meglepő, hiszen az egyfémes verziónál is ilyen összefüggést találtunk. A nanocsöveknél kialakuló 

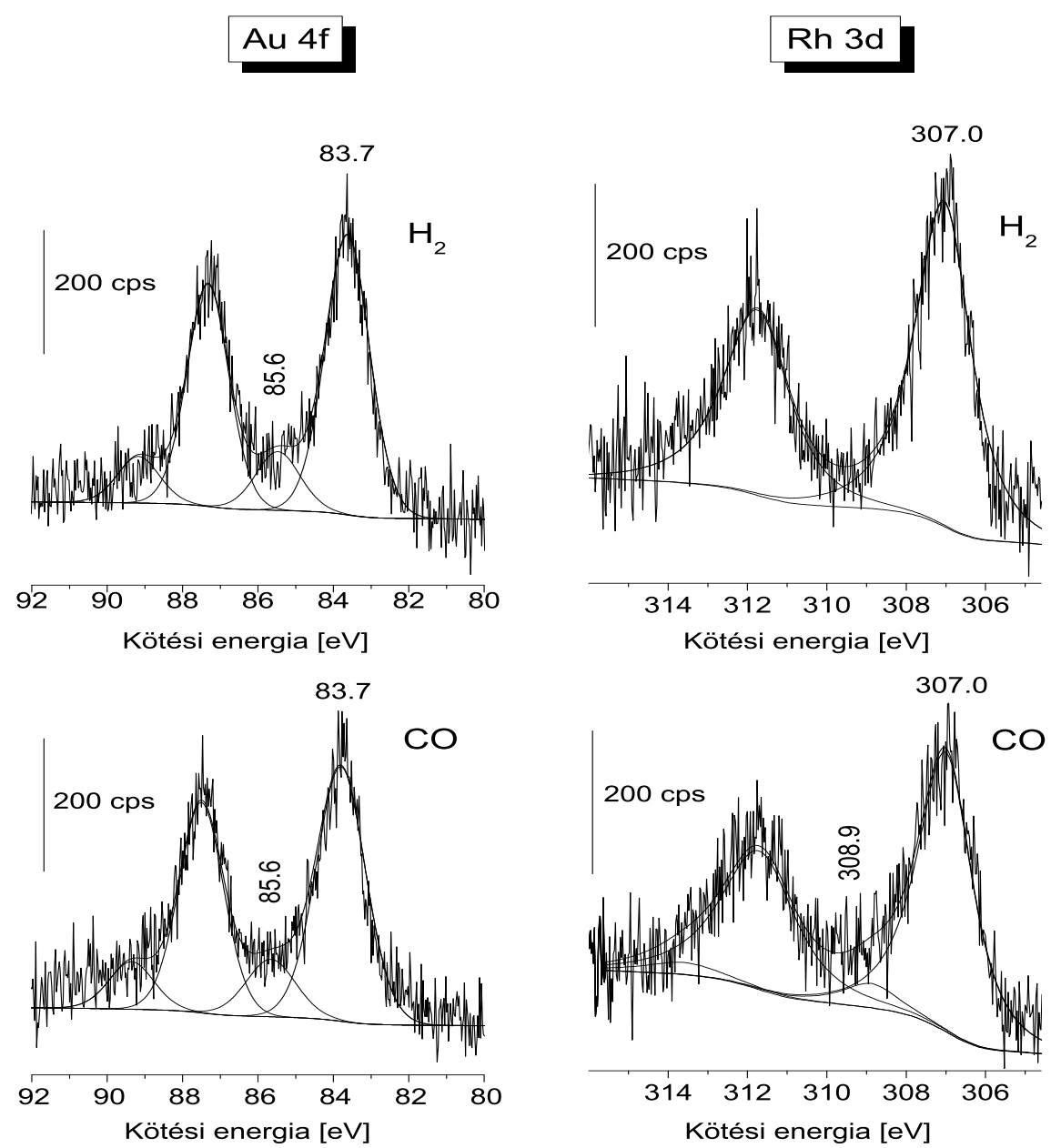

5.10. ábra. 0,5\% $\mathrm{Au}+0,5 \% \mathrm{Rh} / \mathrm{TiO}_{2}$ mintáról felvett $\mathrm{Au} 4 \mathrm{f}$ és $\mathrm{Rh} 3 \mathrm{~d}$ pályák XP spektrumai hidrogénes redukciót, illetve $\mathrm{CO}$ adszorpciót követően

struktúrák megismeréséhez két fémösszetételt használtunk: egyik esetben 0,25\% Au + 0,75 $\% \mathrm{Rh}$, másik esetben $0,5 \% \mathrm{Au}+0,5 \% \mathrm{Rh}$ arányú mintákat. A LEIS mérésekhez $800 \mathrm{eV}$ energiájú hélium ionokat használtunk, a szén-monoxid adszorpciót szobahőmérsékleten, 1,3 mbar nyomáson valósítottuk meg. Az 5.11. ábra spektrumai alapján megállapítható, hogy 1:1 arány mellett redukciót követôen a zaj szintjétől gyengén elkülöníthetô ródiumjelet tapasztalunk, amely a CO hatására kismértékben megerősödik. Ha a ródium mennyisége háromszor annyi, mint az aranyé, akkor a felületen jelen lévő arany már nem képes elfedni a ródiumot, így a spektrumon erőteljes csúcs adódik 707 eV értéknél. Szén-monoxid hatására pedig közel azonos intenzitású jeleket figyelhetünk meg. Mindkét mérésből azt a következtetést vonhatjuk le, hogy szén-monoxid hatására a fémklaszterek felületi összetétele megváltozik. Ennek során Rh-CO kötések alakulnak ki a felületen, ezáltal a ródium atomok detektálhatóvá válnak az ionszórási spektroszkópia számára, még úgy is, hogy a CO molekulák is rendelkeznek bizonyos árnyékoló hatással. 

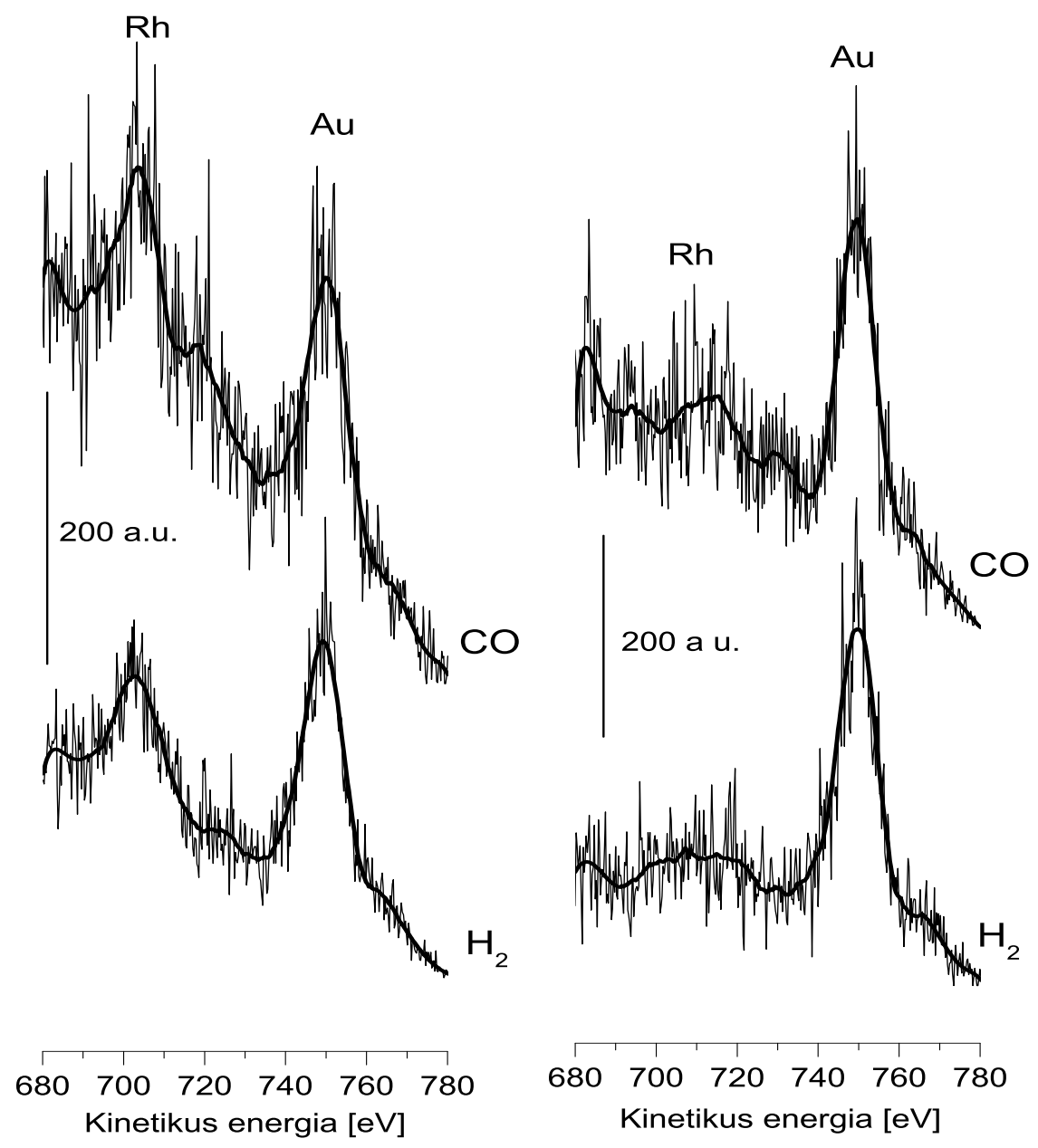

5.11. ábra. $0,25 \% \mathrm{Au}+0,75 \% \mathrm{Rh} / \mathrm{TiO}_{2}$ (A) és $0,5 \% \mathrm{Au}+0,5 \% \mathrm{Rh} / \mathrm{TiO}_{2}$ (B) nanocső mintákról felvett LEIS spektrumok hidrogénes redukciót, illetve $\mathrm{CO}$ adszorpciót követóen

Azonban nem csak a fémrészecskék szétesése, hanem a vele ellentétes aggregáció is lejátszódhat ezeken a rendszereken. Ezt abban az esetben figyeltük meg, mikor a mintákon a $\mathrm{CO}_{2}+\mathrm{H}_{2}$ reakciót játszattuk le $493 \mathrm{~K}$ hômérsékleten [127]. A nanocsőról készített Au $4 \mathrm{f}$ és a Rh 3d spektrumok csúcsfelbontásával kapott összetevő́k változásának tendenciája az 5.12. ábrán követhetô nyomon. Mindkét esetben látható a nagy diszperzitású fémek jele, ám amíg az arany esetében komoly változás nem mutatható ki, addig a ródium jeléhez 30 perces reakció után már gyakorlatilag nem járul hozzá a 308,2eV-os komponens, míg a redukciós lépést követően még egyértelmúen jelen van. A tapasztalt változás minden bizonnyal a ródium aggregációja folytán következik be.

A fenti eredmények azt erôsítik meg, hogy a kialakult mag-héj struktúrát nem egy sta- 
Au $4 f$

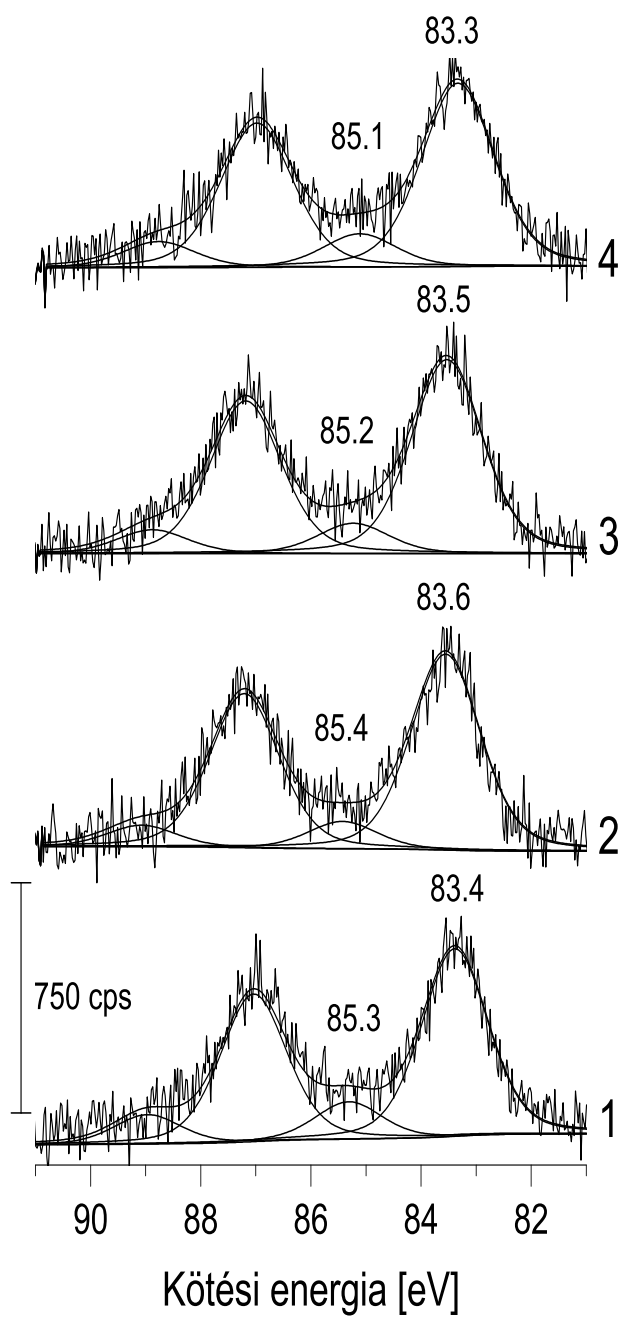

$\operatorname{Rh} 3 d$
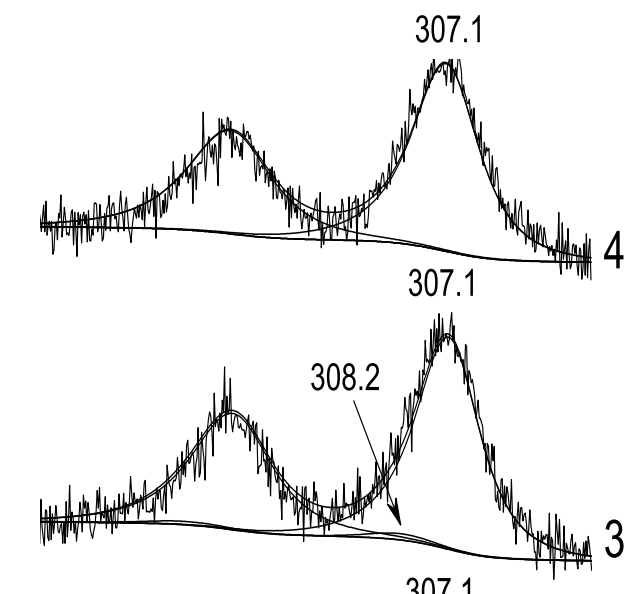

307.1

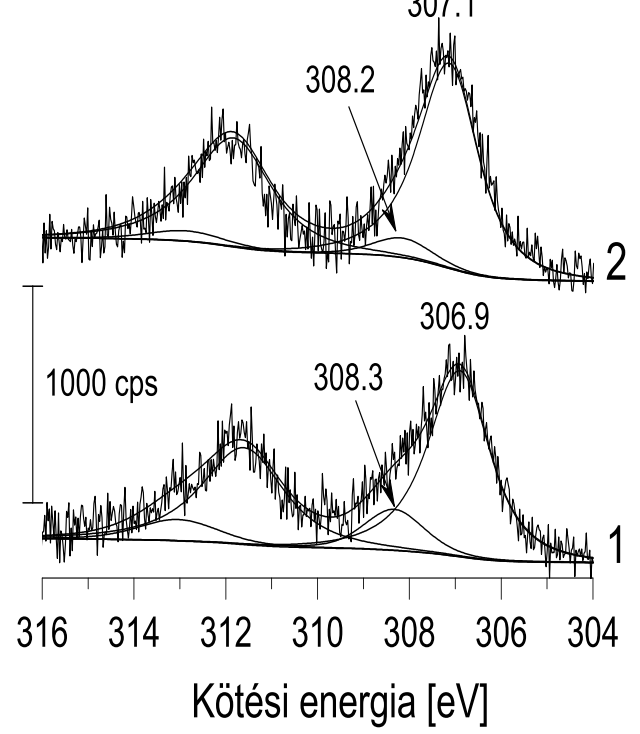

5.12. ábra. $0,5 \% \mathrm{Au}+0,5 \% \mathrm{Rh} / \mathrm{TiO}_{2}$ nanocső $\mathrm{Au} 4 \mathrm{f}$ és $\mathrm{Rh} 3 \mathrm{~d}$ pályák XP spektrumai redukció után (1), 5 perc (2), 30 perc (3) és 120 perc (4) $493 \mathrm{~K}$ hômésékleten végrehajtott $\mathrm{CO}_{2}+\mathrm{H}_{2}$ reakciót követően

tikus képződményként kell felfogni, hanem alkotóelemeinek folyamatos helycseréje valószínúsíthetô. Mivel ebben a rendszerben az arany-arany kötések a leggyengébbek, feltételezhetô, hogy az aranyatomok mobilitása felülmúlja a ródiumatomokét. Ugyan az arany és a szén-monoxid között lényegesen gyengébb kölcsönhatással kell számolni, mint a ródium esetében, de az alkalmazott, viszonylag nagy CO koncentráció mellett már nem elhanyagolható tényező. A felsô aranyrétegen adszorbeálódó CO megváltoztatja a fém-fém kötés erősségét mind az arany, mind a ródium esetében, ami megnövekedett diffúzió sebességet von maga után. Így a ródiumban gazdagabb felületi összetételhez tartozó mikroállapotok valószínúsége növekszik, a szén-monoxid pedig a felületen tartja a ródium atomokat, ami megnövekedett szórási spektrumjel formájában ölt testet. 


\subsubsection{Kobalttal módosított $\mathrm{TiO}_{2}$ nanoszálak és nanocsövek XPS vizs- gálata}

A titanát nanostruktúrák, mint láttuk képesek felületükön nanodiszperz fémklasztereket stabilizálni, ezáltal felkeltve az érdeklődést katalitikus tulajdonságaik megismerésére vonatkozóan. Az oxidhordozó felületére felvitt fém beépülhet a kristályrácsába, mely a katalitikusan aktív helyek számát gyarapítja.

Gyakran használt átmeneti fém a kobalt a Fischer-Tropsch szintézisben, ahol alifás szénhidrogének előállítása a cél. Napjainkban egyre több figyelem fordul a szén-monoxid hidrogénezéséhez használt katalizátorok fémtartalmának kialakítására fém karbonilek felhasználásával. Ennek előnye, hogy a kobalt-karbonil alacsony hőmérsékleten elbontható, ezzel nanoméretű fémrészecskéket hozhatunk létre a hordozó felületén. Magas hőmérsékleten ugyanis a fém aggregációja következik be, illetve $\mathrm{Co}_{2} \mathrm{O}_{3}$ képződés is lejátszódhat az oxidhordozóval történő kölcsönhatás eredményeként. Ez a tényező képezte számunkra a motivációs alapot a kobalt karbonilt tartalmazó titanát nanostruktúrák mélyebb megismeréséhez.

A $\mathrm{Co}_{2}(\mathrm{CO})_{8}$ felületi depozícióját fluidágyas reaktorban hajtották végre alacsony hőmérsékleten. Az így előállított, kobaltra nézve 4 tömegszázalékos terméket ezt követôen szén-monoxid atmoszféra alatt tárolták. Az XPS mérések kiértékelése alkalmával a Ti 2 $\mathrm{p}_{3 / 2}$ csúcsmaximumát (458,9 eV) választottuk referenciának.

UV-látható spektroszkópiai mérésekből tudjuk, hogy a tiltott sáv szélessége 3,14 eV a tiszta nanoszálnál, míg 2\% Co tartalom esetén $2,48 \mathrm{eV}, 4 \%$ Co mellett pedig 2,41 eV. A jelentős csökkenésból a nanoszál és a kobalt között lejátszódó komoly elektromos kölcsönhatásra következtethetünk, sőt az ioncsere lehetőségét sem zárhatjuk ki [128].

A kobalt XP spektrumának kiértékelésekor szem előtt kell tartani, hogy pusztán a $2 \mathrm{p}_{3 / 2}$ csúcspozíció alapján nem tudunk határozott kijelentést tenni a fém oxidációs állapotáról, erre a dublett felhasadásának mértékéből és a szatellitek jelenlétéből tudunk következtetni. A kezeletlen mintákról felvett kobalt spektrumon (5.13. (A) ábra) a dublett $2 \mathrm{p}_{3 / 2}$ tagja 781,7 eV-nál, a 2 $p_{1 / 2}$ tag 797,5 eV-nál jelentkezik és intenzív szatellit csúcsok is megfigyelhetők. A spin-pálya csatolási energia 15,8 eV, ami a $\mathrm{Co}^{2+}$ értékéhez van nagyon közel, míg a fém kobaltra jellemző érték ennél kisebb. Következő lépésben a mintánkat 10 percen át, 600 K hőmérsékleten, nitrogén atmoszférában kezeltük, melynek hatására a karbonil CO széndioxid formában távozott, amit termogravimetriás mérések alapján jelenthetünk ki. A kapott spektrumon (5.13. (B) ábra) a kobalt jelintenzitásában változás nem következett be, viszont a csúcsmaximum 0,7 eV-tal a kisebb kötési energiák irányába mozdult el. A megfigyelt Co $2 p$ fotoemissziós csúcs - a megmaradt szatellitek mellett - magasabb értéknél található, mint a tiszta, fém állapotú kobalté.

A szén-monoxid vesztés nagyon jól nyomon követhető, ha egy pillantást vetünk az oxigén (5.14. ábra) és a szén (5.15. ábra) spektrumokra. Kiindulási állapotban az 530,1 eV-nál 

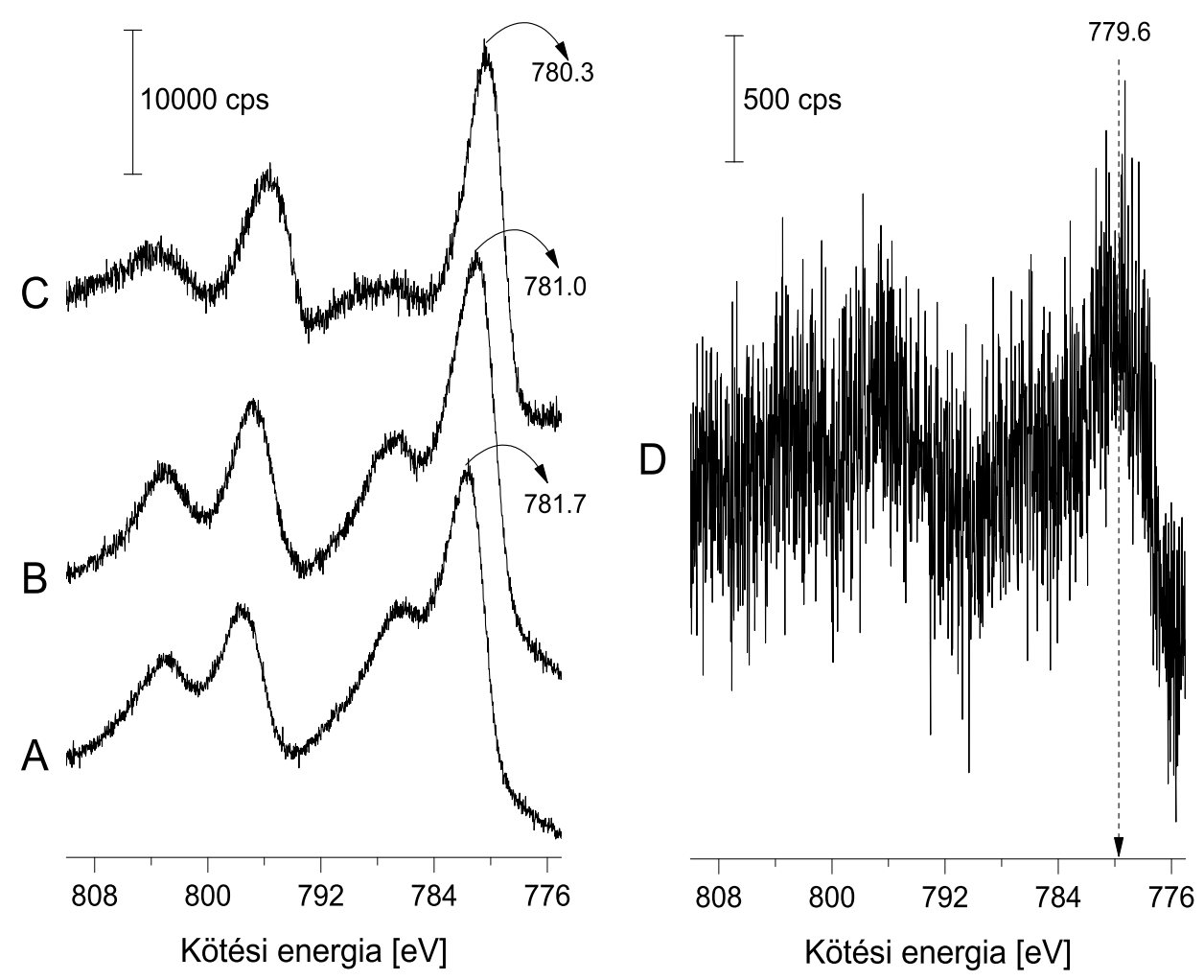

5.13. ábra. 4\% fémtartalmú titán nanoszál Co 2p pályáinak XP spektrumai az egyes kezelési fázisokban: kiindulási állapot (A), 10 perces, $600 \mathrm{~K}$-en végrehajtott kezelés $\mathrm{N}_{2}$ atmoszférában (B), 60 perces, $600 \mathrm{~K}$-en végrehajtott oxidáció $(\mathrm{C}), 60$ perces, $600 \mathrm{~K}$-en végrehajtott redukció (D)

látható rácsoxigén jele mellett további kettő is megfigyelhető 531,7 eV és 532,6 eV értékeknél. Emellett a szénspektrumon a fócsúcs $(285,1 \mathrm{eV})$ mellett két további szintetikus összetevốt lehet kiemelni 288,6 eV és 289,6 eV pozíciókkal. A hőkezelést követően ezeknek a komponenseknek csökkent drasztikusan az intenzitása a $\mathrm{C} 1 \mathrm{~s}$ és az $\mathrm{O} 1 \mathrm{~s}$ spektrumokon, vagyis ezek jelenléte a szén-monoxidhoz köthető. Ezek az eredmények azt sugallják, hogy szobahőmérsékleten kétféle karbonil van jelen egyidejűleg, feltehetôen $\mathrm{Co}_{2}(\mathrm{CO})_{8}$ és $\mathrm{Co}_{4}(\mathrm{CO})_{12}$ formában, melyekben eltérô a CO molekulák orientációja. Hôkezelés hatására az 531,7 eV és az 532,6 eV energiájú csúcsok intenzitása jelentôsen lecsökken, ami már valószínúleg a CO hiánya miatt megfigyelhető két- és egyfogású oxigénektől származik. Az 530,1eV kötési energiájú oxigén esetén semmilyen változás nem állapítható meg a különbözô kezelési fázisokban.

A $\mathrm{N}_{2}$ atmoszférába végrehajtott hőkezelést egy oxidációs lépés követett ( $600 \mathrm{~K}, 60$ perc). A Co $2 p_{3 / 2}$ csúcs helye a kisebb kötési energiák irányába tolódott (780,3 eV) és intenzitása is csökkent (5.13. (C) ábra). Emellett domináns szatellit jelenlétrôl sem beszélhetünk. Ezek a változások az oxidképződés következtében állhatnak elő, illetve a fémaggregátumok en- 
A
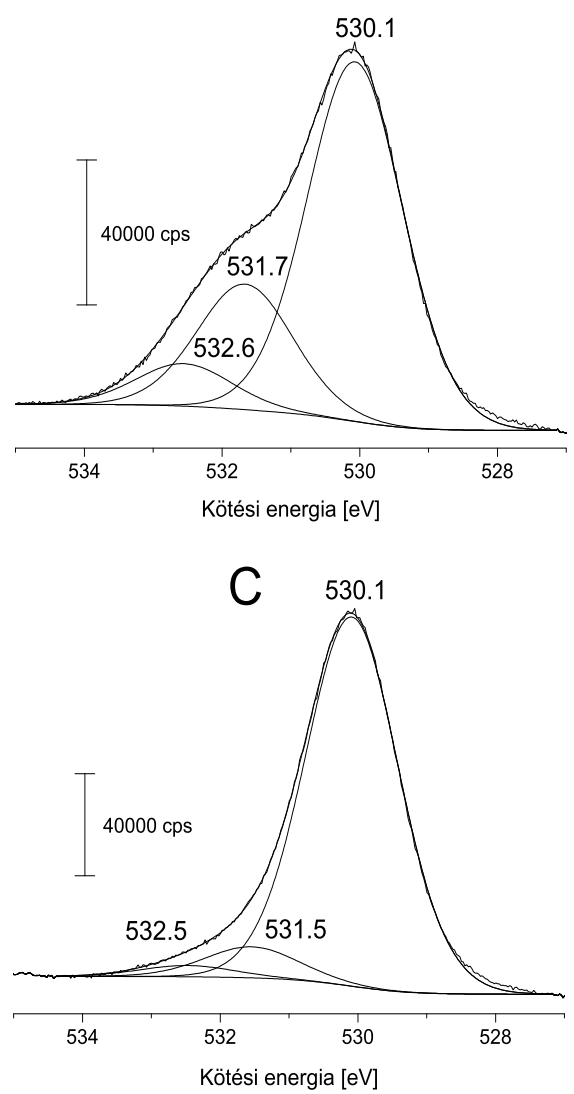

B
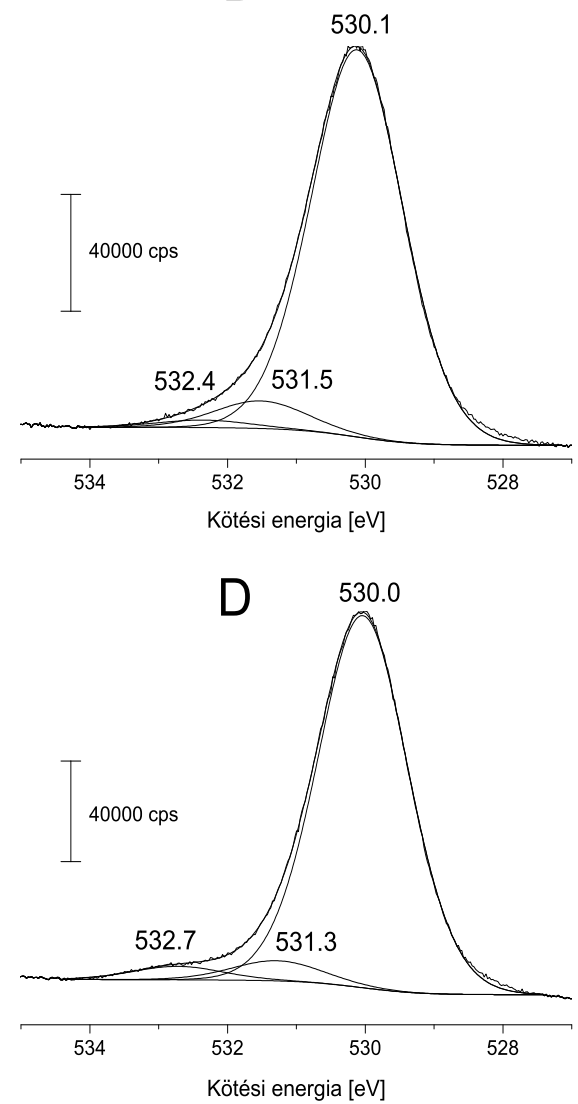

5.14. ábra. 4\% fémtartalmú titán nanoszál O 1s pályáinak XP spektrumai az egyes kezelési fázisokban: kiindulási állapot (A), hőkezelés (10 perc, $600 \mathrm{~K}, \mathrm{~N}_{2}$ atmoszféra (B), oxidáció (60 perc, $600 \mathrm{~K})(\mathrm{C})$, redukció (60 perc, $600 \mathrm{~K}, \mathrm{H}_{2}$ áram) (D)

kapszulációja sem zárható ki. A következő lépésben hidrogénes redukciót alkalmaztunk, 600 K-en, 1 órán át. Legszembetúnóbb változás a kobalt XP jelének drasztikus csökkenése, ami a tömbfázisba irányuló diffúzióból eredhet. Továbbá a mért csúcsmaximum 779,6 eV energiánál adódik, amiből a kobalt redukcióját olvashatjuk ki (5.13. (D) ábra).

Az eredmények értelmezésekor nem zárható ki, hogy a karbonil elbomlása után a visszamaradó kobalt a felület oxigénvakanciáinak erôterében található, nagy diszperzitású, kis részecskeméretú klaszterek formájában. A tapasztalt kötési energia eltolódást így a méretcsökkenéssel tudjuk összefüggésbe hozni. A kobalt klaszterek stabilizációs mechanizmusok révén elektront adhatnak át a hordozónak, ami a magasabb kötési energiákat indokolhatja. Sasahara és munkatársai Pt nanorészecskéket tartalmazó $\mathrm{TiO}_{2}$ felületen kilépési munka csökkenést állapítottak meg, ami a Pt-ból a hordozó irányába mutató elektronátadásnak tudható be [129]. 600 K-re felfütött, $2 \%$ fém tartalmú mintákon HRTEM segítségével nem lehetett kobalt részecskéket kimutatni. Diffúz reflexiós UV/Vis spektroszkópia alapján ionkicserélódés feltételezhetô a nanoszál és a fém között. XPS mérések értékelhetetlenül kis intenzitású 

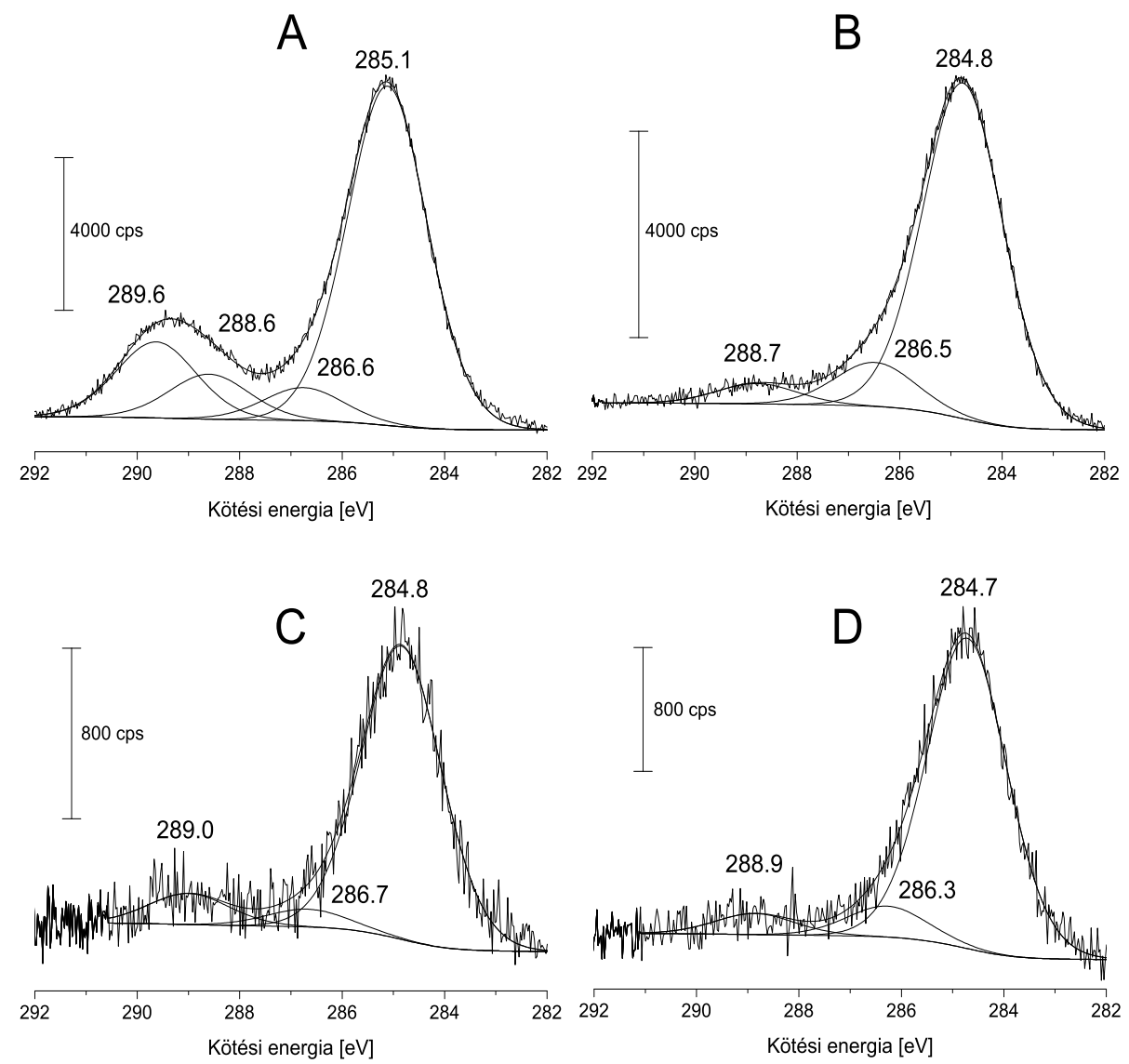

5.15. ábra. 4\% fémtartalmú titán nanoszál $\mathrm{C}$ 1s pályáinak XP spektrumai az egyes kezelési fázisokban: kiindulási állapot (A), hôkezelés (10 perc, $600 \mathrm{~K}, \mathrm{~N}_{2}$ atmoszféra (B), oxidáció (60 perc, $600 \mathrm{~K})(\mathrm{C})$, redukció (60 perc, $600 \mathrm{~K}, \mathrm{H}_{2}$ áram) (D)

Co spektrumokat szolgáltattak, ami összhangban van az előbb említett eredményekkel. 4\% kobalt tartalom mellett azonban már jól láthatók a fémklaszterek HRTEM-mel [128]. Ekkor már az ionkicserélődés nem játszódik le teljes mértékben, ami az aktív centrumok telítôdésével indokolható. Ezt követően, a dekarbonilezés után megjelenő kobalt atomok klaszterképződéssel tudnak stabilabb állapotba kerülni. 


\subsection{Katalizátorok kémiai reakciók hatására bekövetkezố felületmódosulásának vizsgálata}

\subsubsection{Száraz reformálás $\mathrm{Rh} / \mathrm{Al}_{2} \mathrm{O}_{3}, \mathrm{Rh} / \mathbf{1 0} \% \mathrm{TiO}_{2}-\mathrm{Al}_{2} \mathrm{O}_{3}$ és $\mathrm{Rh} / 10 \% \mathrm{~V}_{2} \mathrm{O}_{5}$ - $\mathrm{Al}_{2} \mathrm{O}_{3}$ katalizátorokon}

Szén-dioxid reformálása során hidrogén és szén-monoxid elegyet állítanak elő, ahol valamilyen szénhidrogént használnak reakciópartnerként, megfelelő katalizátor jelenlétében. Ennek egyik ipari jelentősége, hogy megfelelő összetételû reaktáns elegyet szolgáltat a szintetikus motorhajtóanyagok és kenőanyagok előállításához. Nem mellékes szempont, hogy az üvegházhatású gázok átalakításának is egyik alternatívájaként jöhet szóba, így a környezetvédelemben betöltött szerepére is érdemes rávilágítani. A száraz reformáláshoz $\left(\mathrm{CO}_{2}+\mathrm{CH}_{4}\right.$ $=\mathrm{H}_{2}+\mathrm{CO}$ ) használt katalizátorok tulajdonságának javítására irányuló kutatások napjainkban is folynak. A VIII. csoport átmenenetifémeinek száraz reformálási reakcióban mutatott katalitikus sajátságainak kutatása gazdag ismeretanyagot ölel fel [130]. A nemesfémtartalmú katalizátorok hatékonyságát több esetben is sikerült igazolni, ahol a $\mathrm{CO}_{2}+\mathrm{CH}_{4}$ reakcióban mutatott aktivitás a következő sorrendben csökken: $\mathrm{Ru}, \mathrm{Pd}, \mathrm{Pt}, \mathrm{Ir}$, ami megegyezik a $\mathrm{CO}_{2}$ disszociáció esetén tapasztalt aktivitással [131-134]. Ha a ródium tartalmú rendszerek vizsgálatára öszpontosítunk, akkor a katalitikus aktivitás tekintetében felállított sorrend a következőképpen alakul: $\mathrm{Rh} / \mathrm{Al}_{2} \mathrm{O}_{3}>\mathrm{Rh} / \mathrm{TiO}_{2}>\mathrm{Rh} / \mathrm{SiO}_{2}$ [135]. Ezzel szemben Bitter és munkatársai a ródium aktivitást nem a hordozó anyagi minőségével hozták összefüggésbe, hanem a ródium hozzáférhetőségével érveltek [136]. Viszont aktivitásnövekedésrôl számoltak be akkor is, mikor a $\mathrm{Rh} / \mathrm{SiO}_{2} \mathrm{Al}_{2} \mathrm{O}_{3}$-ot, $\mathrm{TiO}_{2}$-ot és $\mathrm{MgO}$-ot is tartalmazott [135]. Úgy tűnik, hogy a hordozóként használt oxidok/oxidkeverékek a $\mathrm{CO}_{2}$ felületi disszociációját segítik elő, ami a $\mathrm{CH}_{4}+\mathrm{CO}_{2}$ reakció sebességmeghatározó lépése. Száraz reformálási reakcióban a $\mathrm{Rh} / \mathrm{SiO}_{2}$ katalizátor megnövekedett aktivitásáról számoltak be abban az esetben, mikor a rendszer vanádium-oxidot is tartalmazott. [137] Ezen ismeretek birtokában három katalizátort vizsgáltunk száraz reformálási reakcióban: $\mathrm{Rh} / \mathrm{Al}_{2} \mathrm{O}_{3}, \mathrm{Rh} / 10 \% \mathrm{TiO}_{2}-\mathrm{Al}_{2} \mathrm{O}_{3}$ és $\mathrm{Rh} / 10 \% \mathrm{~V}_{2} \mathrm{O}_{5}-\mathrm{Al}_{2} \mathrm{O}_{3}$.

A katalizátorok előállítása impregnálással történt ipari $\mathrm{Al}_{2} \mathrm{O}_{3}$ hordozóból, $\mathrm{NH}_{4} \mathrm{VO}_{3}$ és titán-izopropilát tartalmú oldatok felhasználásával. A 10 tömegszázalék $\mathrm{V}_{2} \mathrm{O}_{5}$-ot és $\mathrm{TiO}_{2}$-ot tartalmazó terméket 773 K hőmérsékletú szárítás, majd hőkezelés után nyerték. Ezután újabb impregnálást hajtottak végre, melynek során 1 tömegszázalék ródiumot tartalmazó terméket állítottak elő $\mathrm{RhCl}_{3}$-oldattal.

A reakciót megelőzően a katalizátorokat előkezeltük, melynek elsô lépése egy oxidációból (30 perc, $673 \mathrm{~K}$ ), majd ezt követő hidrogénes redukcióból (60 perc, $773 \mathrm{~K}$ ) állt. A vizsgált $\mathrm{CH}_{4}+\mathrm{CO}_{2}$ reakciót $773 \mathrm{~K}$ hőmérsékleten hajtottuk végre. 
A kutatócsoportunkban végzett katalitikus mérések, a felületi fématomok számára vonatkoztatva, a $\mathrm{Rh} / \mathrm{V}_{2} \mathrm{O}_{5}-\mathrm{Al}_{2} \mathrm{O}_{3}$ rendszeren $50 \%$-kal nagyobb aktivitást mutattak a CO képződésre nézve, mint a $\mathrm{Rh} / \mathrm{Al}_{2} \mathrm{O}_{3}$-on [138]. Az irodalomban fellelhetố információk arról adnak számot, hogy a $\mathrm{TiO}_{2}$ hordozón megfigyelhető aktivitás a redukció következtében kialakuló felületi $\mathrm{TiO}_{x}$ hibahelyek megjelenésével hozható összefüggésbe [139]. Aktivitásnövekedést figyeltek meg akkor is, mikor $\mathrm{Pt} / \mathrm{ZrO}_{2}$ katalizátorhoz cériumot adtak [140], ezáltal növelve a felületi oxigén vakanciák számát, mely kulcsfontosságú tényezőnek tekinthetô a reformálási reakcióban, a $\mathrm{CO}_{2}$ disszociáció szempontjából.

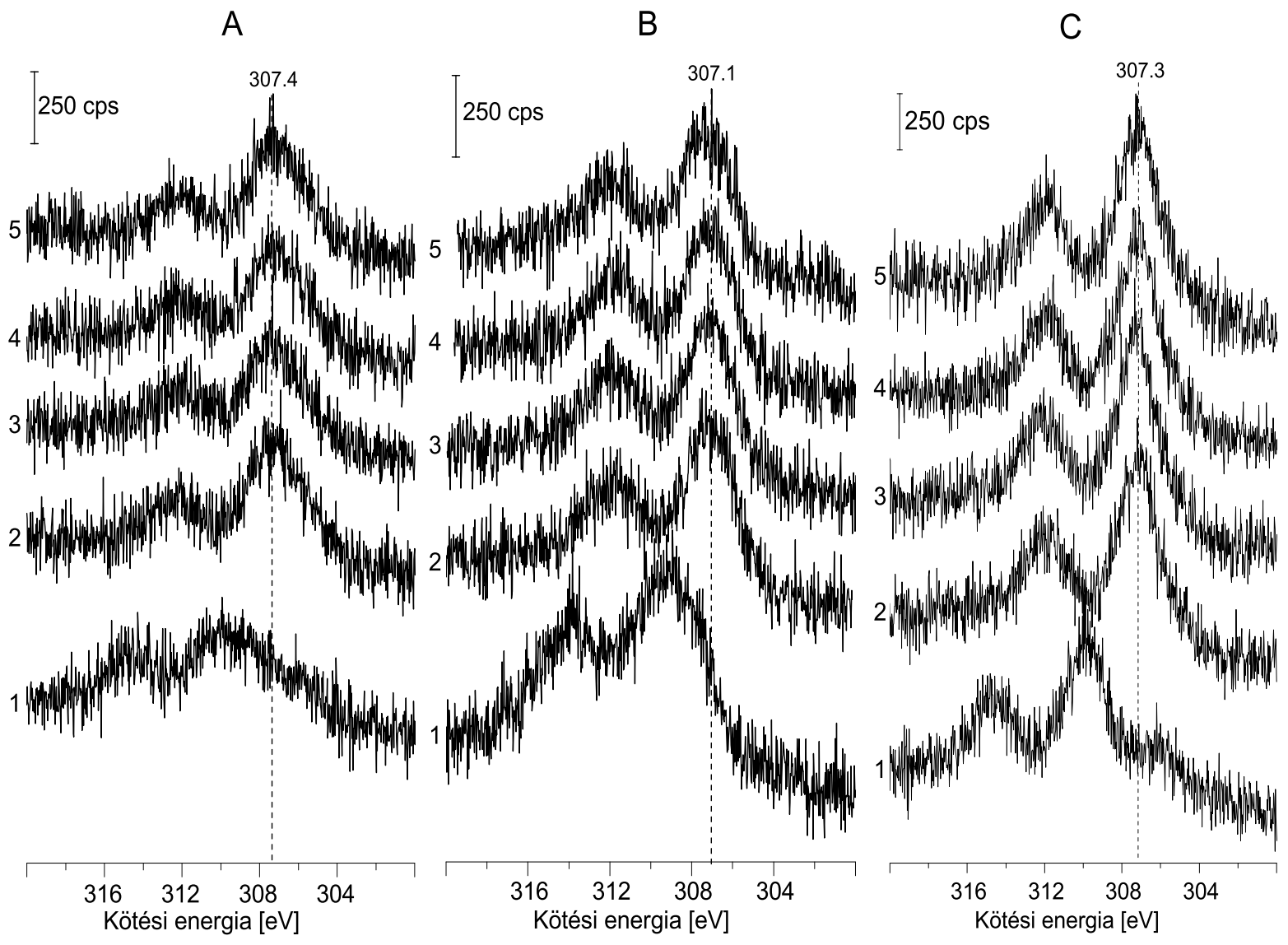

5.16. ábra. Rh 3d XP spektrumok $\mathrm{Rh} / \mathrm{Al}_{2} \mathrm{O}_{3}(\mathrm{~A}), \mathrm{Rh} / 10 \% \mathrm{TiO}_{2}-\mathrm{Al}_{2} \mathrm{O}_{3}(\mathrm{~B}), \mathrm{Rh} / 10 \% \mathrm{~V}_{2} \mathrm{O}_{5^{-}}$ $\mathrm{Al}_{2} \mathrm{O}_{3}(\mathrm{C})$ mintákról kiindulási állapotban (1), redukció (2), 5 perc (3), 30 perc (4) és 120 perc (5) $773 \mathrm{~K}$ hômérsékleten végrehajtott $\mathrm{CH}_{4}+\mathrm{CO}_{2}$ reakció után

Az egyes előkezelési és reformálási reakciókat követôen rögzítésre került ródium spektrumok összehasonlítását az 5.16. ábra alapján végezhetjük el. A kiindulási állapotú rendszerekben a $\mathrm{Rh} 3 \mathrm{~d}_{5 / 2}$ csúcs pozíciója (309,2 - 309,8 eV) $\mathrm{Rh}^{3+}$ jelenlétét mutatja. Redukciót követôen mindhárom esetben csökkent a kötési energia értéke: $\mathrm{Rh} / \mathrm{Al}_{2} \mathrm{O}_{3}$-ban 307,4 $\mathrm{eV}, \mathrm{Rh} / \mathrm{TiO}_{2}-\mathrm{Al}_{2} \mathrm{O}_{3}$-ban 307,1 eV és $\mathrm{Rh} / \mathrm{V}_{2} \mathrm{O}_{5}-\mathrm{Al}_{2} \mathrm{O}_{3}$-ban 307,3 eV. A reformálási reakciók sem a csúcspozíciókat, sem az intenzitásviszonyokat nem módosították. A kötési energi- 
ákra meghatározott 307,3 eV és 307,4 eV pozíció 0,3-0,4 eV-tal nagyobb, mint a tömbfázisú ródiumra jellemző érték. A jelenség magyarázatára itt is alkalmazhatjuk a nanostruktúrált titanátok vizsgálata során tett megállapításainkat, miszerint a kötési energia növekedése a részecskeméret csökkenésével függhet össze. A csúcspozíciók állandósága azt támasztja alá, hogy a reakció során a ródium oxidációs állapotában nem következik be változás.

Ha összehasonlítjuk a $\mathrm{Rh} / \mathrm{TiO}_{2}-\mathrm{Al}_{2} \mathrm{O}_{3}$-ról felvett Ti 2p csúcsok sorozatát (5.17. (B) ábra), néhány tized eV kötési energia csökkenést figyelhetünk meg a redukciót követôen. Ez a kismértékú eltolódás a reakció hatására bekövetkező titán redukciójával hozható összefüggésbe.

A

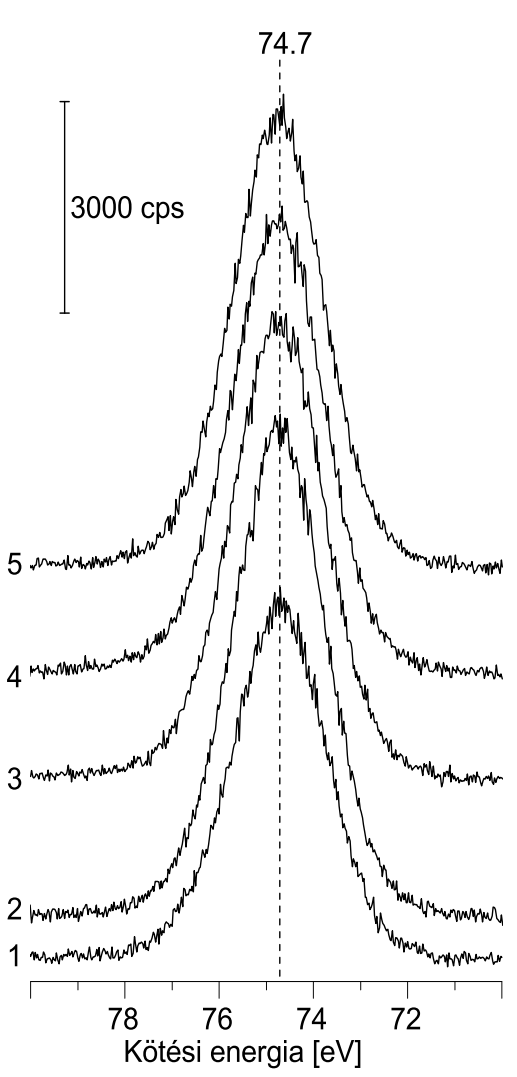

B

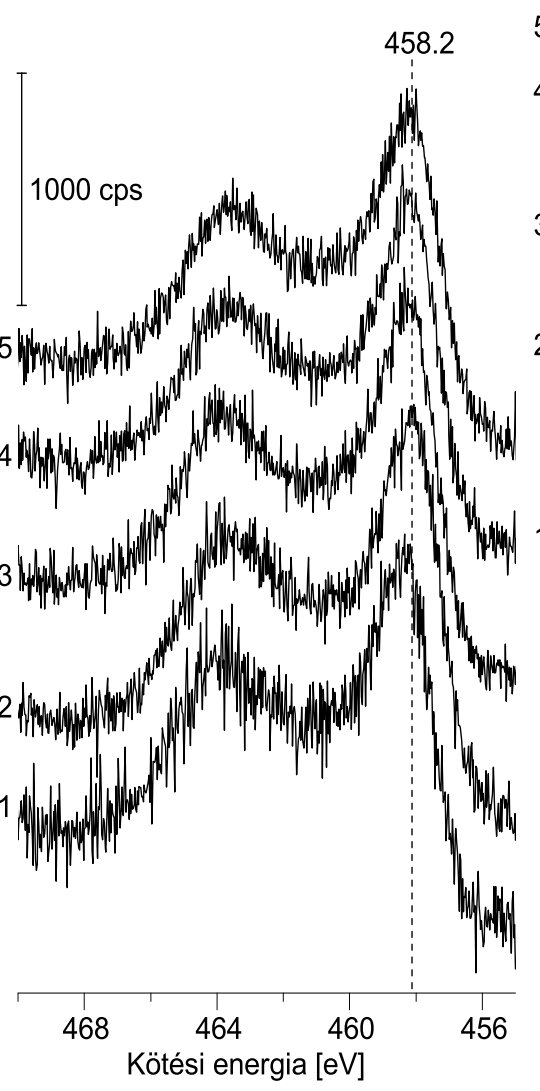

C

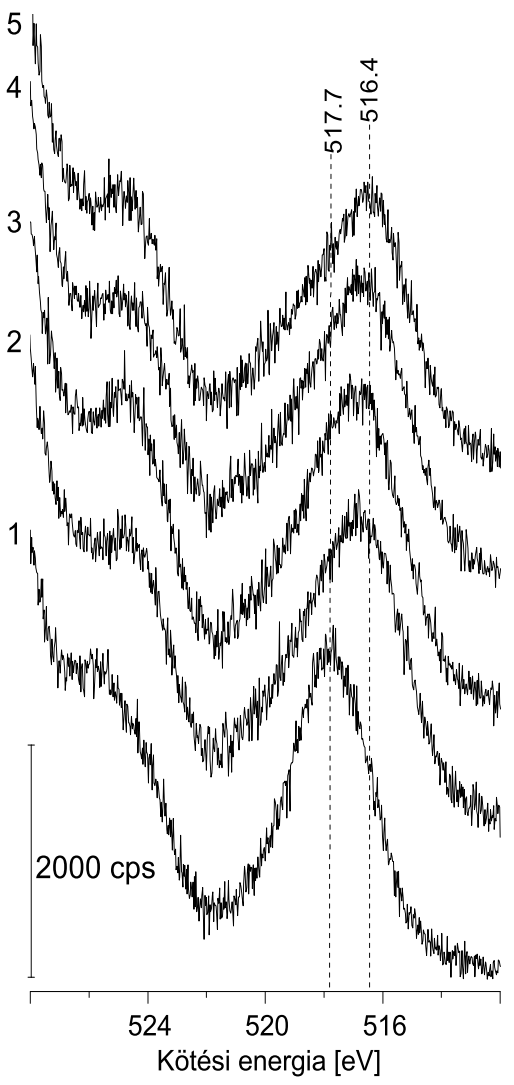

5.17. ábra. $1 \% \mathrm{Rh} / \mathrm{Al}_{2} \mathrm{O}_{3} \mathrm{Al} 2 \mathrm{p}$ spektrumai (A), $\mathrm{Rh} / 10 \% \mathrm{TiO}_{2}-\mathrm{Al}_{2} \mathrm{O}_{3}$ Ti $2 \mathrm{p}$ spektrumai (B), $\mathrm{Rh} / 10 \% \mathrm{~V}_{2} \mathrm{O}_{5}-\mathrm{Al}_{2} \mathrm{O}_{3} \mathrm{~V} 2 \mathrm{p}$ spektrumai (C) kiindulási állapotban (1), redukció (2), 5 perc reakció (3), 30 perc reakció (4) és 120 perc (5) $773 \mathrm{~K}$ hőmérsékleten végrehajtott $\mathrm{CH}_{4}+\mathrm{CO}_{2}$ reakció után

A $\mathrm{V}_{2} \mathrm{O}_{5}$-dal adalékolt katalizátorokról felvett $\mathrm{V} 2 \mathrm{p}$ esetén már szembetûnőbb változásokat figyelhetünk meg (5.17. (C) ábra). A V 2p csúcsok kiértékelésére azt követôen nyílt lehetôség, miután eltávolítottuk az O 1s jelétôl származó, átfedô szatellit csúcsokat. A redukció után rögzített spektrumokon a 2 p pálya kötési energiája a $\mathrm{V}^{4+}$-nak megfelelő $516,4 \mathrm{eV}$ érték, amely egybecseng a TPR mérésekből levonható következtetésekkel is. Sigl és munka- 
társai vanádiummal adalékolt $\mathrm{Rh} / \mathrm{SiO}_{2}$ katalizátort vizsgáltak $\mathrm{CH}_{4}+\mathrm{CO}_{2}$ reakcióban és arra a megállapításra jutottak, hogy a vanádium oxidációs állapotában szignifikáns változás nem következik be [137]. Ezzel szemben a mi méréseink arról tanúskodnak, hogy a vanádium kötési energiájában jelentôs eltolódás tapasztalható redukciót követôen. Az eltolódás mértékéből arra is következtetni tudunk, hogy a rendszerben $\mathrm{V}^{4+}$ található. Ha a katalizátoron nincs jelen ródium, a $\mathrm{V}^{5+} \rightarrow \mathrm{V}^{4+}$ redukció nem játszódik le $773 \mathrm{~K}$ hőmérsékleten. A mi esetünkben minden bizonnyal a ródium felületen aktiválódott hidrogén redukálja a vanádiumot.

Egy olyan reakcióban, melyben széntartalmú reaktánsok szerepelnek, érdemes a katalizátor felületi széntartalmának változását is nyomon követni. A rögzített $\mathrm{C}$ 1s spektrumok kötési energiájában lényeges eltérés nem mutatható ki, csak a csúcsok intenzitásnövekedése következik be a reakció előrehaladtával.

A vizsgált reakcióban tapasztalt aktivitásnövekedés a $\mathrm{V}^{4+}$ jelenlétéhez köthető. Ebben az állapotban a vanádium nem stabil, a visszaoxidáció termodinamikailag kedvezményezett. Ez részben a hordozón generál oxigénvakanciákat, másrészt a $\mathrm{CO}_{2}$ disszociációját idézi elő. Ez magyarázza a katalizátor lényegesen nagyobb aktivitását a vanádiummentes hordozókhoz képest. A folyamat úgy is értelmezhető, hogy a ródium katalizálja a vanádium redukcióját, ami a szén-dioxid disszociációjának katalizátoraként aktivitásnövekedést eredményez a $\mathrm{CH}_{4}+\mathrm{CO}_{2}$ reakcióban.

\subsubsection{Dimetil karbonát szintézise rézzel adalékolt szén nanocsövön}

A dimetil karbonát (DMC) előnyös tulajdonságai között említhetjük környezetbarát jellegét, mely napjainkban mindinkább felértékelődik ha vegyipari alapanyagokról beszélünk. Szintetikus reakciókban metilezó reagensként használják, illetve mivel nem sorolják az illékony szerves vegyületek (VOC) közé, oldószerként való hasznosítása is jelentôs. Szintézisére több lehetôség is adódik, mint például a foszgén reakciója metilalkohollal, metanol gázfázisú oxidatív karbonilezése, propilén karbonát metanollal végrehajtott átészterezési reakciója. Ezekkel a reakciókkal szemben az a kifogás fogalmazható meg, hogy korrozív, mérgező és gyúlékony gázok felhasználásával valósulnak meg. Ahhoz, hogy a dimetil karbonátot valóban a környezetbarát vegyületek között tarthassuk számon, egy környezetkímélő szintézisút kidolgozása is szükséges.

Az egyik lehetséges, általunk is vizsgált megvalósítás a metanol gázfázisú oxidatív karbonilezésére épül, rézzel adalékolt, kloridmentes többfalú szén nanocső hordozón. A nanocsô elóállítása acetilén katalitikus bontásával történt, $5 \% \mathrm{Co}+\mathrm{Fe} / \mathrm{Al}_{2} \mathrm{O}_{3}$ katalizátoron, 993 $\mathrm{K}$ hőmérsékleten, egy állóágyas reaktorban. Ezután a termék $\mathrm{NaOH}$ oldattal végrehajtott tisztítása következett, amit egy $\mathrm{HCl}$ oldatos semlegesítési fázis zárt le. A felületi réztartalom kialakítása impregnálásos technikával történt számított mennyiségú $\mathrm{Cu}\left(\mathrm{NO}_{3}\right)_{2}$ oldat 
felhasználásával. A szárítás után rendelkezésre álló katalizátor rézre nézve 10 tömegszázalék összetételú volt.

Az előkezelési fázisban $693 \mathrm{~K}$ hőmérsékleten, 1 órán keresztül, hidrogén áramban redukáltuk a mintát. A vizsgált reakciót ezt követôen hajtottuk végre 393 K hômérsékleten, a felület összetételének és a katalizátor oxidációs állapotában bekövetkezett változások nyomon követése érdekében 10, 50 és 150 perc elteltével spektrumokat vettünk fel. Az áttekintő spektrumok alapján szennyező anyagok jelenlétét kizárhatjuk. Nagy felbontású XP spektrumok a $\mathrm{Cu} 2 \mathrm{p}, \mathrm{O}$ 1s és a Cu LMM régiókról kerültek rögzítésre. A reaktánselegy összetételét 2:1:1 ( $\left.\mathrm{CH}_{3} \mathrm{OH}: \mathrm{CO}: \mathrm{O}_{2}\right)$ arányúra állítottuk, az áramlási sebesség $16 \mathrm{ml} /$ perc nagyságú volt.

A C 1s nagyfelbontásban felvett spektruma 1,35 eV félértékszélességgel bíró, a szén nanocsövekre jellemző plazmon szatellitek miatt a nagyobb kötési energiájú oldalon aszimmetrikus lefutású jel. Az alakja és intenzitása nem mutat számottevő változást a reakciók után. Ezért a C 1s spektrum tanulmányozása nem nyújt felvilágosítást arra nézve, hogy a reakció következtében milyen módon változik a felületi széntartalmú vegyületek mennyisége, összetétele. Ennek az az egyszerú oka, hogy a hordozó teljesen elfedi ezen vegyületekből származó fotoelektronok jelét.

A
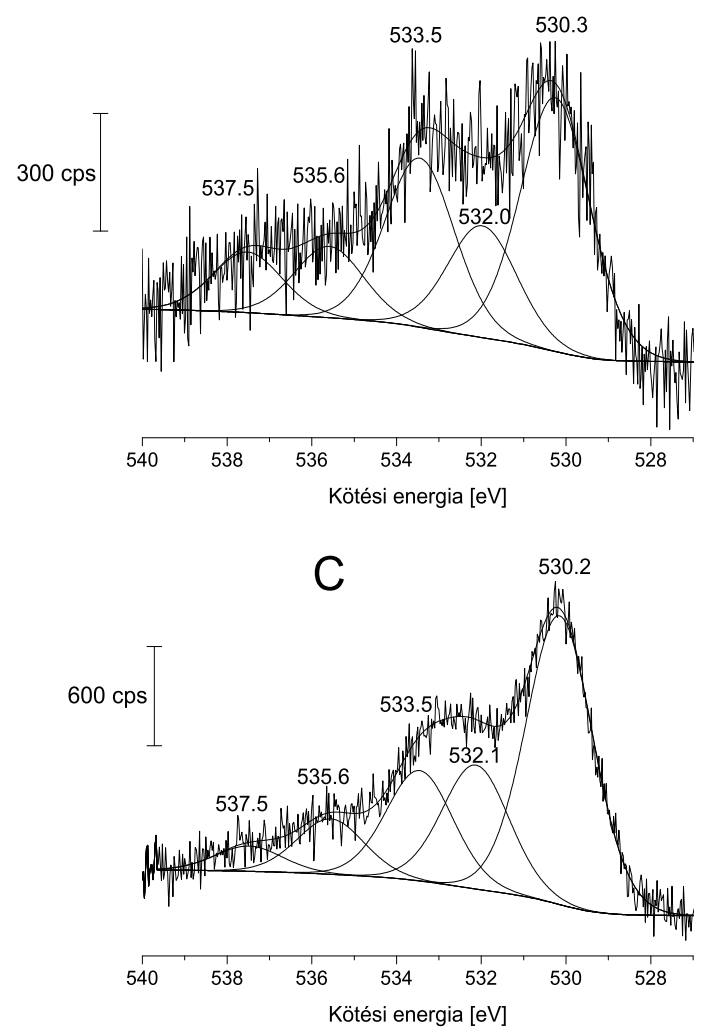

B
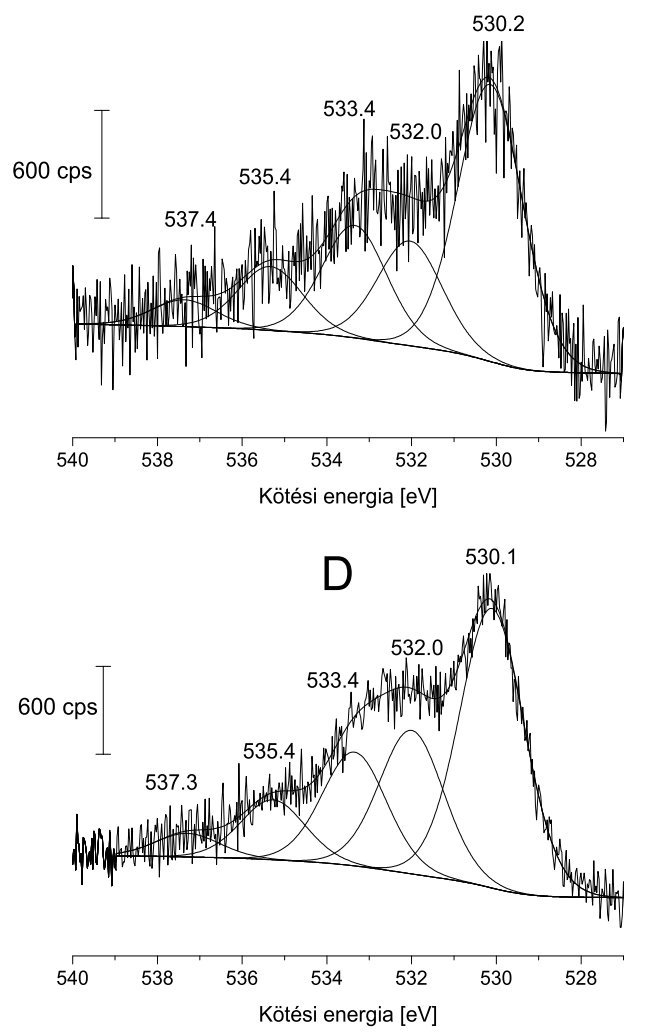

5.18. ábra. O 1s pályák XP spektrumai Cu/MWCNT mintán kiindulási állapotban (A), 10 perc (B), 50 perc (C), 150 perc (D) $393 \mathrm{~K}$ hőmérsékleten végrehajtott $\mathrm{CH}_{3} \mathrm{OH}+\mathrm{CO}+\mathrm{O}_{2}$ reakció után 
Az O 1s spektrumok ezzel szemben sokkal összetettebb alakúak, a nagyobb kötési energiájú oldalon hosszabb lefutással (5.18. ábra). A dekonvolúciót követően kapott 535,5 és 537,5 eV energiák környékén megjelenő komponensek a réz Auger sorozatának tagjai. Így ténylegesen három összetevő köthetô magához a felületi oxigénekhez: 530,1-530,3 eV, 532,0532,1 eV és 533,4-533,6 eV energiáknál, ahol az első esetben megadott érték egyben a legnagyobb intenzitású a három közül. Jelentős, 25 \%-os intenzitáscsökkenést figyeltünk meg a redukció hatására, majd közel kétszeres növekedés következett be 10 perces reakció után. Mivel redukciót követôen a réz fémes állapotban van jelen és oxidációját követően új komponensek nem jelennek meg az oxigén jelben, ezért ebből arra következtethetünk, hogy a detektált komponensek szén nanocsövek C-O kötéseitôl származnak. A CuO-ban az oxigén 1s pályájának kötési energiája 529,6 eV körül található, de a szénhez kapcsolódó oxigének domináns jele mellett nem lehet kimutatni ezt a mi rendszerünkben.

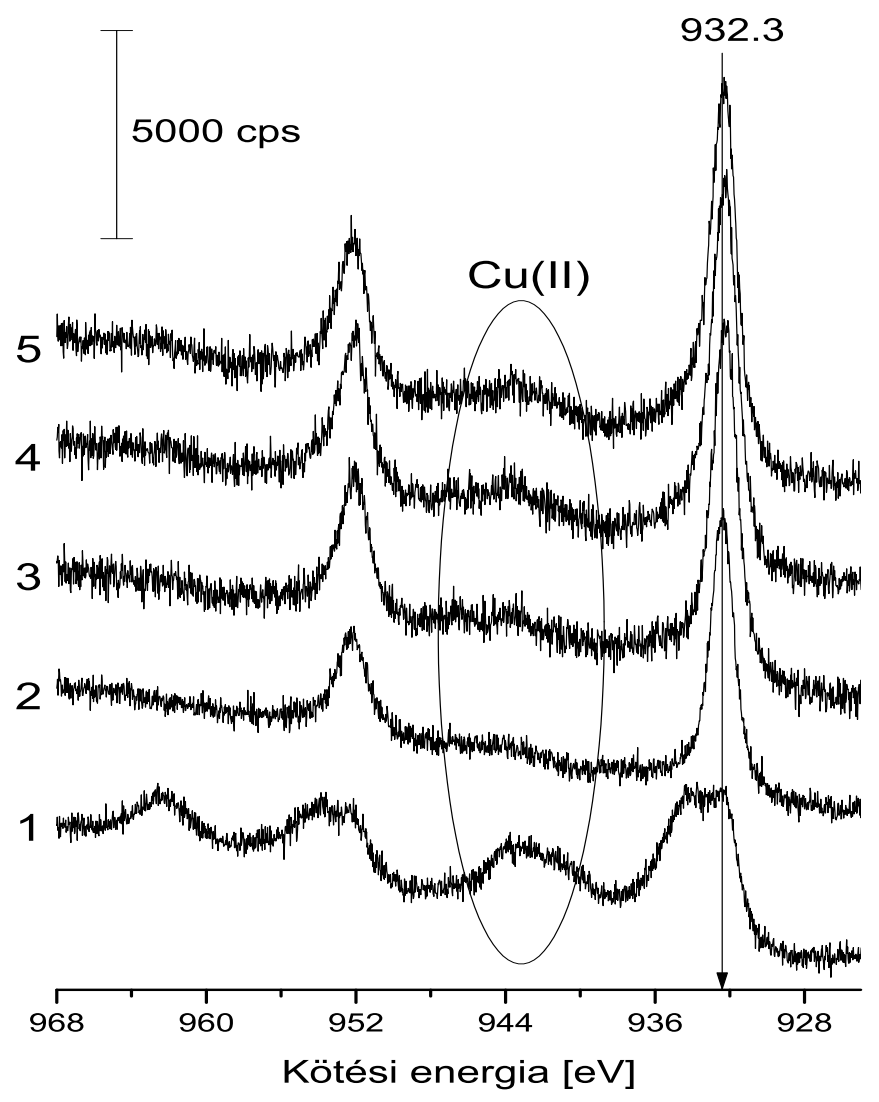

5.19. ábra. $\mathrm{Cu} 2 \mathrm{p}$ XP spektrumok Cu/MWCNT mintán kiindulási állapotban (1), redukció (2), 10 perc (3), 50 perc (4), 150 perc (5) $393 \mathrm{~K}$ hőmérsékleten végrehajtott $\mathrm{CH}_{3} \mathrm{OH}+\mathrm{CO}+\mathrm{O}_{2}$ reakció után

A réz esetében az oxidációs állapot önmagában a 2p csúcspozíciók alapján nem állapítható meg, ehhez a szatellit csúcsok jelenlétét (hiányát) és az Auger paraméter értékét is figyelembe kell venni a helyes következtetések meghozatalakor. A szatellitek jelenléte a fém-ligandum között lejátszódó töltésátmenet következtében lejátszódó shake-up gerjeszté- 
sekkel áll kapcsolatban. A töltésátmenet a $\mathrm{Cu}^{2+}\left(3 \mathrm{~d}^{9}\right.$ konfiguráció) esetén játszódik le, ezért ebben az oxidációs állapotban szatellitcsúcsok is megfigyelhetők a $\mathrm{Cu} 2 \mathrm{p}$ spektrumokon, míg $\mathrm{Cu}^{+}$és $\mathrm{Cu}^{\circ}$ ( $3 \mathrm{~d}^{10}$ konfiguráció) esetében ezzel nem kell számolni. A kezeletlen állapotról felvett $\mathrm{Cu} 2 \mathrm{p}$ dublett a $\mathrm{Cu}\left(\mathrm{NO}_{3}\right)_{2}$ és annak bomlásából származó $\mathrm{CuO}$ jelenlétének nyomát viseli magán, melyek a 935,5 eV és a 932,3eV kötési energiáknál látható összetevóket eredményezik. Az 5.19. ábra 1. spektrumán látható szatellit csúcsok azt igazolják, hogy a réz +2 oxidációs állapotban van jelen. 60 perces redukció után a $\mathrm{Cu} 2 \mathrm{p}_{3 / 2}$ csúcs 935,5 eV-os komponense eltünik, a 932,2 eV-os rész esetében jelentős intenzitásnövekedés tapasztalható, ugyanakkor a szatellit jelenlétével sem kell számolni. Ezen információk alapján is kijelent-

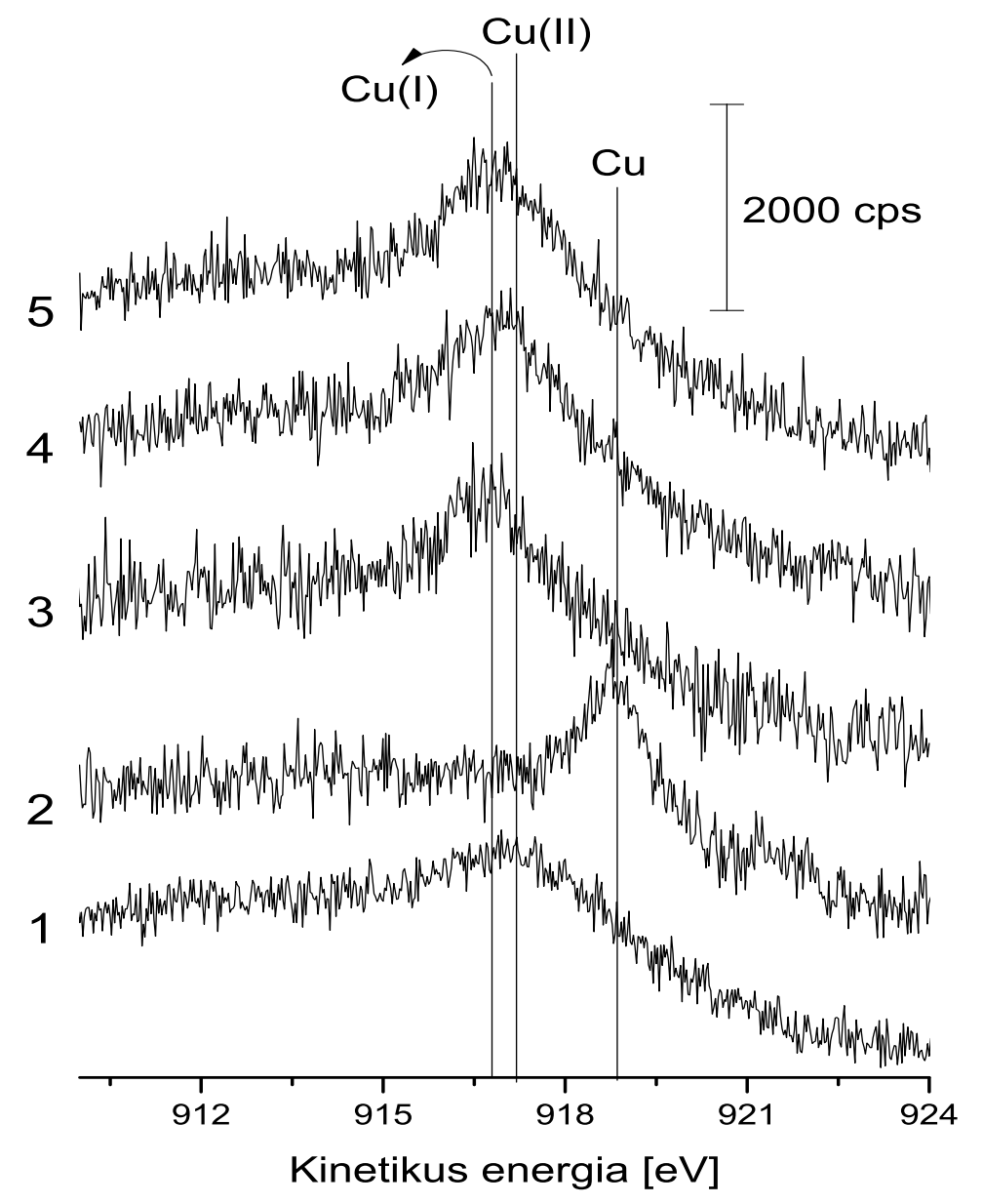

5.20. ábra. $\mathrm{Cu}$ LMM XP spektrumok Cu/MWCNT mintán kiindulási állapotban (1), redukció (2), 10 perc (3), 50 perc (4), 150 perc (5) $393 \mathrm{~K}$ hőmérsékleten végrehajtott $\mathrm{CH}_{3} \mathrm{OH}+\mathrm{CO}+\mathrm{O}_{2}$ reakció után

hetjük, hogy fém réz található a felületen, amit a Cu LMM spektrum (5.20. ábra) segítségével megállapított Auger paraméter értéke $(1851 \mathrm{eV})$ is alátámaszt, mely a $\mathrm{Cu} 2 \mathrm{p}_{3 / 2}$ fotoelektron csúcs kötési energiájának és a $\mathrm{Cu} \mathrm{L}_{3} \mathrm{MM}$ Auger csúcs kinetikus energiájának összegeként áll elő. Információt szolgáltat a kémiai környezeten túl a kristályok struktúrájáról és a re- 
laxációs energiáról is, miközben értéke nem függ a minta elektrosztatikus feltöltődésének hatásától. A reakciót követôen a kötési energiában nem látunk változást, viszont már 10 percet követően megjelenik 942 eV-nál a szatellitcsúcs. A $\mathrm{CH}_{3} \mathrm{OH}+\mathrm{CO}+\mathrm{O}_{2}$ reaktánselegy hatására az Auger spektrumokon is jól látható változások következnek be a redukált fázisról rögzítettekhez képest. Ebből arra következtethetünk, hogy a fém réz +1 és +2 állapotra oxidálódik vissza, melyek közül a $\mathrm{Cu}^{+}$van jelen a felületen domináns mértékben. A reakcióidő előrehaladtával a $\mathrm{Cu}^{2+}$ mennyisége növekszik, melyre a szatellit intenzitásváltozásából következtethetünk. A spektrumokon az is látszik, hogy a reakció lejátszódásával a $\mathrm{Cu} 2 \mathrm{p}$ csúcs alatti területe 50 percig növekszik, majd 150 perc után már lényegesen nem módosul. Ez a felületi réz mennyiségének növekedésére utal.

Gázkromatográfiás mérésekből tudjuk, hogy a metanol konverziója az első egy órában növekszik, ami az XPS mérések alapján összefüggésben áll a felületi réz mennyiségével. A reakció első néhány percében a dimetil karbonát képződése csekély mértékú. Mivel ebben a fázisban fém réz nincs a felületen, ezért a katalitikus aktivitás minden bizonnyal az oxidált állapotú réznek tulajdonítható. 


\section{6. fejezet}

\section{Összefoglalás}

Titanát nanocsövek és nanoszálak vizsgálata is tárgyát képezte kutatásainknak, melyeket anatáz hidrotermális konverziójával nyernek, forgó autokláv alkalmazásával. Vizsgálataink során arany és ródium egy- illetve kétfémes rendszereket tanulmányoztunk, ahol a hordozó szerepét a nanostrukturált titanátok játszák. A fémeket impregnálással vitték a felületre, $\mathrm{HAuCl}_{4}$ és $\mathrm{RhCl}_{3}$ oldatokból. A kiindulási állapotú mintákon $300{ }^{\circ} \mathrm{C}$ hőmérsékleten, 30 perces oxigénes, majd $300{ }^{\circ} \mathrm{C}$-on, 60 perces hidrogénes reakciókat hajtottunk végre, az egyes fázisokban pedig XP spektrumokat vettünk fel.

$\mathrm{Az} 1 \mathrm{w} \% \mathrm{Au} / \mathrm{TiO}_{2}$ nanoszál, redukált állapotú minta $\mathrm{Au} 4 \mathrm{f}$ spektruma két komponenssel illeszthető: 83,7 eV és 85,6 eV, az Au 4f $7 / 2$ csúcsok esetén. Az utóbbi nem köthető magasabb oxidációs állapotú aranyhoz, hiszen ez a redukció után jelenik meg. Ennek magyarázatához figyelembe kell venni, hogy minél nagyobb a fémek diszperzitás, és minél kisebb mértékben érvényesül az extra-atomi relaxációs hatás, annál nagyobb kötési energiák irányába fog tolódni a felvett XP spektrum. Vagyis a 85,6 eV kötési energiával jellemezhető arany nagyon kisméretú fém nanorészecskékhez köthető (1-1,5 nm). Az 1 w\% Au/ $\mathrm{TiO}_{2}$ nanocsövek esetében a 85,6 eV-os komponens továbbra is megfigyelhetô, viszont lényegesen kisebb intenzitással. $\gamma-\mathrm{Al}_{2} \mathrm{O}_{3}$ és $\mathrm{TiO}_{2}$ Degussa $\mathrm{P} 25$ hordozókon nem lehet kimutatni a nagy diszperzitású nanoméretû aranyrészecskék jelenlétét. Figyelemreméltó különbség állapítható meg ezen mérések alapján a kétféle titanát nanostruktúra között: a nanoszál lényegesen hatékonyabban képes stabilizálni a nagyon kis méretû aranyrészecskéket, mint ahogy a nanocső teszi.

Az 1 w\% Rh/TiO 2 nanoszál minták redukcióját követôen egy 307,1 eV (fémes állapotú ródium) kötési energiájú fő́csúcs és egy 309,3 eV-os kis intenzitású összetevô látható. Ez utóbbit nagy diszperzitású fém jelenlétéhez köthetjük, hasonló megfontolások alapján, mint amit az arany esetében is láthatunk. Szobahőmérsékleten végrehajtott szén-monoxid adszorpciót követően szembetúnő változást figyelhetünk meg, ugyanis a nagyobb kötési energiájú oldalon fokozódik a Rh 3d spektrumban meglévő aszimmetrikus jelleg. A magyará- 
zat szintén a fém részecskék diszperzitásnövekedésében keresendő, ugyanis a szén-monoxid elősegíti a ródiumrészecskék szétesését.

A kétfémes rendszerek vizsgálatakor mind a nanoszál, mind a nanocső esetén a nagyobb diszperzitású arany részecskék jelintenzitásának $(85,6$ eV) komoly csökkenését tapasztaljuk. Mindeközben a Rh 3d $5 / 2$ 309,3 eV körüli komponensének a mennyisége is kisebb lesz. Ezek a mérési eredmények magyarázhatók a kétfémes klaszterek - egyfémes rendszerekhez viszonyított - méretének növekedésével. Az arany nagy felületi diffúziója révén képes a ródium részecskéket beborítani, elfedni. Ezen folyamat termodinamikai hajtóereje a felületi energia csökkenésével értelmezhető. Ezáltal úgynevezett mag-héj szerkezet alakul ki, ahol az arany játsza a héj, a ródium pedig a mag szerepét. Kisenergiájú ionszórási spektroszkópiával végzett mérések is ezt támasztják alá. Az 0,5\% Au + 0,5\% Rh tartalmú kétfémes rendszerek esetén ródiumot nem detektálunk, csak aranyat $756 \mathrm{eV}$-nál, melynek a jelintenzitása lényegesen nagyobbnak adódik az egyfémes rendszerhez képest. Ez egyértelmúen igazolja a mag-héj szerkezet kialakulását. Az arany LEIS jelének intenzitásnövekedése arra mutat rá, hogy a ródium részecskék enkapszulációja során megnő a felületen tartózkodó aranyatomok száma, nő az arany diszperzitása. Szén-monoxid hatására a ródium LEIS intenzitásában jelentôs növekedés tapasztalható, ami arra utal, hogy a CO képes a mag-héj szerkezetú fémrészecskék felületi struktúrájának megváltozását előidézni. Ezáltal a ródium felületi koncentrációja megnő, amit a bekötő szén-monoxid molekula nem képes teljes mértékben leárnyékolni.

Titanát nanocső hordozó arany, ródium kétfémes rendszerét szén-dioxid hidrogénezésének reakciójában is vizsgáltuk. A ródium spektrumot két komponenssel illeszthetjük (Rh $3 \mathrm{~d}_{5 / 2}$ ): a 306,9-307,1 eV a fémhez, míg 308,1 eV a nagy diszperzitású ródiumhoz tartozik. A $\mathrm{CO}_{2}+\mathrm{H}_{2}$ gázkeverékkel végrehajtott reakció során mindvégig ez a két kompones adódik. A nagydiszperzitású ródium intenzitása folyamatosan csökken a reakció során, 60 percet követően gyakorlatilag már kimutathatatlan mennyiségben van jelen. Az Au 4f spektrumok illesztése szintén két komponenssel végezhetô, ahol az Au 4f $7 / 2$-re 83,6-83,3 eV (fém arany, nagyobb intenzitású komponens) és 85,4-85,1 eV (nagydiszperzitású, kisebb intenzitású komponens) kötési energiájú összetevőket detektálunk. A reakciók folyamán az arany spektrumán számottevő változás nem következik be sem az intenzitás, sem a csúcspozíciók tekintetében. A kis méretű ródium részecskék jelintenzitásának csökkenése az agglomerizációval értelmezhető.

Protonált $\mathrm{TiO}_{2}$ nanoszálakon kobalt nanorészecskéket is kialakítottunk és jellemeztünk. A titanát nanostruktúrák felületének Co tartalmát $\mathrm{Co}_{2}(\mathrm{CO})_{8}$ alacsony hőmérsékletű hőbontása útján hoztuk létre. UV-látható spektroszkópia a tiltott sáv szélességének éles csökkenését mutatja 3,14 eV-ról 2,41 eV-ra, ha a kobalt mennyiségét 4 \%-ig növeljük a nanoszál felületén. Megállapíthatjuk, hogy a kobalt egy része ionkicserélődési folyamatban vesz részt. Nagyobb mennyiségú fém alkalmazása esetén a hordozó felületének oxigénvakanciáihoz kö- 
tődő, nanoméretben diszpergált kobalt részecskék jönnek létre. Ezeknek az átlagos mérete leginkább 2 és 6 nm közötti tartományban található.

Fémet nem tartalmazó nanoobjektumokon rögzített $\mathrm{O}$ 1s spektrumok csúcsfelbontásával négyféle oxigént tudtunk megkülönböztetni. Ezek segítségével tanulmányoztuk mintáink fázisátalakulását különböző hőmérsékleteken, 60 perces hőkezelést követően. Legérdekesebb megfigyelés az előzóek során erősen lecsökkent 533,5 eV-os komponens újra megjelenése $673 \mathrm{~K}$ hőmérsékleten. Ennek egyik oka a nanocsövek belsejéből felszínre került víz, vagy formil-csoportok felületi képződése lehet.

$\mathrm{TiO}_{2}$ és $\mathrm{V}_{2} \mathrm{O}_{5}$ komponensekkel adalékolt, $\mathrm{Al}_{2} \mathrm{O}_{3}$ hordozóra felvitt ródium katalizátorokat is vizsgáltunk $\mathrm{CH}_{4}+\mathrm{CO}_{2}$ reakcióban. A reakció során a $\mathrm{Rh} 3 \mathrm{~d}$ spektrumok csúcspozícióiban és intenzitásban nem tapasztalunk változást. A mért értékek $\left(\mathrm{Rh} / \mathrm{Al}_{2} \mathrm{O}_{3}: 307,4 \mathrm{eV}\right.$, $\mathrm{Rh} / \mathrm{TiO}_{2}-\mathrm{Al}_{2} \mathrm{O}_{3}: 307,1 \mathrm{eV}, \mathrm{Rh} / \mathrm{V}_{2} \mathrm{O}_{5}-\mathrm{Al}_{2} \mathrm{O}_{3}: 307,3 \mathrm{eV}$ ) néhány tized eV energiával magasabbak, mint ami a fém ródiumra jellemzô. Összességében megállapíthatjuk, hogy a ródium 0 oxidációs állapota a reakció során változatlan marad. A Ti $2 p$ elektronok kötési energiája kismértékú csökkenést mutat redukció hatására, míg a $\mathrm{CH}_{4}+\mathrm{CO}_{2}$ gázeleggyel történt reakciók nem okoznak további változást a $\mathrm{Rh} / \mathrm{TiO}_{2}-\mathrm{Al}_{2} \mathrm{O}_{3}$ katalizátor esetében. $\mathrm{A} \mathrm{V}_{2} \mathrm{O}_{5}$ tartalmú katalizátorokban ezzel szemben sokkal egyértelmúbb változásokat figyelhetünk meg. A kiindulási állapotú, kezeletlen mintát összehasonlítva a redukált fázissal, a szatellit eltávolítása után kapott V 2p spektrumokból egyértelmúen látszik a vanádium oxidációs állapotának csökkenése. A kiindulási állapotban mért 517,7 eV érték a $\mathrm{V}^{5+}$ oxidációs állapotnak felel meg, míg a hidrogénezést követôen adódott 516,4 eV kötési energia érték a $\mathrm{V}^{4+}$ jelenlétének tulajdonítható. Az általunk elvégzett XPS mérések eredményeit a TPR vizsgálatok is alátámasztják.

Vizsgáltuk a réz oxidációs állapotának változását többfalú szén nanocsövön metanol oxidatív karbonilezésének reakciójában, a dimetil karbonát szintézisének céljából. A Cu 2p spektrumok intenzív szatellit csúcsainak redukciót követô eltûnése a fémes állapot megjelenését igazolja. A reakció lejátszódásának kezdetétől a réz oxidációját tapasztaljuk, mely során főként $\mathrm{Cu}^{+}$és kisebb mértékben $\mathrm{Cu}^{2+}$ van jelen a felületen, amire az újra megjelenő szatellit sávokból és az Auger paraméter értékéből következtethetünk. Az eredmények azt támasztják alá, hogy a DMC képződése a $\mathrm{Cu}^{+} / \mathrm{Cu}^{2+}$ felületi koncentrációaránytól függ. 


\section{7. fejezet}

\section{Summary}

In our studies we have dealt with titanate nanotubes and nanowires prepared by hydrothermal conversion of anatase in a rotating autoclave. We have studied mono- and bimetallic systems where nanostructures play the role of the supports. Metal content has been produced by impregnation with $\mathrm{HAuCl}_{4}$ and $\mathrm{RhCl}_{3}$ solutions. On the samples as prepared we first carry out first an oxidation treatment at $300{ }^{\circ} \mathrm{C}$ for $30 \mathrm{~min}$, then a hydrogen treatment at $300{ }^{\circ} \mathrm{C}$ for $60 \mathrm{~min}$, and in each state XP spectra are taken.

In the case of $1 \mathrm{w} \% \mathrm{Au} / \mathrm{TiO}_{2}$ nanowire two peaks have observed on the reduced sample for $\mathrm{Au} 4 \mathrm{f}_{7 / 2}$ at $83.7 \mathrm{eV}$ and $85.6 \mathrm{eV}$. The latter component cannot be attributed to any kind of higher oxidation state gold because it only appears after hydrogen treatment. For explanation we have to take into account the following phenomenon: the higher is the dispersity of the metal particles and the smaller is the extra atomic relaxation effect, the more significant shift of the XP spectrum is observed toward higher binding energies. We may attribute the component at $85.6 \mathrm{eV}$ to gold atoms in very small sized nanoparticles (1-1.5 nm). On 1 $\mathrm{w} \% \mathrm{Au} / \mathrm{TiO}_{2}$ we find a peak at $85.6 \mathrm{eV}$ binding energy with a significantly smaller intensity. However, highly dispersed gold nanoparticles are not observed on $\gamma-\mathrm{Al}_{2} \mathrm{O}_{3}$ and $\mathrm{TiO}_{2}$ Degussa P25 supports. Remarkable difference can be established between the two kind of titanate nanostructures: nanowires have the ability to stabilize very small sized gold clusters in a more efficient manner than nanotubes.

After reduction on $1 \mathrm{w} \% \mathrm{Rh} / \mathrm{TiO}_{2}$ nanowire samples the dominant $\mathrm{XP}$ peak for $\mathrm{Rh} 3 \mathrm{~d}_{5 / 2}$ appears at $307.1 \mathrm{eV}$ (metallic state) and an additional component at $309.3 \mathrm{eV}$ with much smaller intensity. The appearance of the latter sign is explained by the presence of atomically dispersed metal similarly to the case of gold. In the following step we have performed carbon monoxid adsorption at room temperature and a salient change is observed, since the asymmetric character on the higher binding energy side of the $\mathrm{Rh} 3 \mathrm{~d}$ has increased. This can be explained by the fact that $\mathrm{CO}$ induces the disruption of rhodium to smaller sizes.

In the course of the investigation of bimetallic systems both on nanowires and on nan- 
otubes we have experienced significant intensity loss of very small sized gold particles at 85.6 $\mathrm{eV}$. At the same time the $\mathrm{Rh} 3 \mathrm{~d}_{5 / 2}$ peak centered at $309.3 \mathrm{eV}$ has decreased as well. These measured results may be explained by the growth of metal clusters on bimetallic nanoobjects relative to the monometalic case. Due to higher surface diffusivity, gold atoms are able to cover rhodium particles. The thermodinamical driving force may be the decrease of surface energy. The process leads to the formation of a core-shell structure, where the shell consists of gold atoms and the rhodium atoms are positioned in the core region. The results of low energy ion scattering measurements support this assumption. In the case of $0.5 \% \mathrm{Au}+0.5 \%$ $\mathrm{Rh}$ bimetallic nanocomposites rhodium signal is not observed, only the gold scattering signal appears at $753 \mathrm{eV}$ with higher intensity compared to the monometallic case. This is a clear evidence of the formation of a core-shell structure. The increase in the LEIS signal of gold means that a significant part of them are present on surface positions encapsulating the rhodium atoms which results in higher dispersion rate of gold. Carbon monoxid is able to modify the surface composition of core-shell structured metal particles, which is proved by increased LEIS intensity of rhodium signal after carbon monoxid adsorption. The surface concentration of rhodium atoms becomes higher, while the shadowing effect of the binding CO molecules do not fully suppress the LEIS signal of the metal.

We have investigated gold and rhodium bimetallic systems on titanate nanotubes supports in the hydrogenation of carbon dioxid as well. Rhodium spectra are deconvoluted into two components: 306.9-307.1 eV (metallic state) and 308.1 eV (highly dispersed state) for $\mathrm{Rh}$ $3 \mathrm{~d}_{5 / 2}$. The Rh signal always containes these components in all stages of the reaction with the $\mathrm{CO}_{2}+\mathrm{H}_{2}$ gas mixture. The intensity of the highly dispersed component gradually decreases and nearly completely vanishes after $60 \mathrm{~min}$ of the reaction. The Au $4 \mathrm{f}$ spectrum can be also fitted with two doublets: 83.6-83.3 eV (metallic state, more intense component) and 85.4-

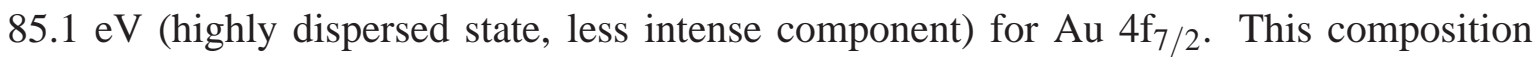
remaines practically unchanged throughout the reaction as far as the intensity and the peak position are concerned.

Co nanoparticles have been produced and characterized on protonated titanate nanowires. Co deposits have been obtained after low-temperature decomposition of $\mathrm{Co}_{2}(\mathrm{CO})_{8}$ on titanate nanostructures. The band gap of Co-decorated titanate nanostructures determined by UV-VIS spectroscopy decreases sharply from $3.14 \mathrm{eV}$ to $2.41 \mathrm{eV}$ with increasing Co content up to $4 \mathrm{w} \%$. A certain amount of cobalt undergoes an ion exchange process. Higher cobalt loadings lead to the formation of nanosized-dispersed particles complexed to oxygen vacancies. The average sizes have been found to be mostly between 2 and $6 \mathrm{~nm}$.

Deconvolution of observed photoemission for $\mathrm{O} 1 \mathrm{~s}$ peaks has revealed four kinds of oxygen atoms on metallic free nanoobjects. By means of these components we have monitored phase transformation of nanowires and nanotubes kept at different temperatures for 60 
min. The most interesting result is observed at $673 \mathrm{~K}$ where the diminished photoemission at $533.5 \mathrm{eV}$ reappears only on nanotubes. This could be the result of the release of water moieties from nanotube channels or the formation of formate-like surface species.

Our group has investigated the effect of $\mathrm{TiO}_{2}$ and $\mathrm{V}_{2} \mathrm{O}_{5}$ additives on $\mathrm{Rh}$ promoted $\mathrm{Al}_{2} \mathrm{O}_{3}$ support in $\mathrm{CO}_{2}+\mathrm{CH}_{4}$ reaction. The intensity and the peak position of the $\mathrm{Rh} 3 \mathrm{~d}$ spectra on the three samples remains unchanged in all stages of the reaction. The measured values $\left(\mathrm{Rh} / \mathrm{Al}_{2} \mathrm{O}_{3}\right.$ : $\left.307.4 \mathrm{eV}, \mathrm{Rh} / \mathrm{TiO}_{2}-\mathrm{Al}_{2} \mathrm{O}_{3}: 307.1 \mathrm{eV}, \mathrm{Rh} / \mathrm{V}_{2} \mathrm{O}_{5}-\mathrm{Al}_{2} \mathrm{O}_{3}: 307.3 \mathrm{eV}\right)$ lay some tenth $\mathrm{eV}$ higher than that for metallic bulk rhodium. We can state that the 0 oxidation state of rhodium does not change during the reaction. The binding energy of Ti $2 p$ electrons in the $\mathrm{Rh} / \mathrm{TiO}_{2}-\mathrm{Al}_{2} \mathrm{O}_{3}$ shifts only a few tenth $\mathrm{eV}$ downwards after the reduction of the catalyst, but does not change during the reaction. On the contrary, significant shift is observed in the case of $\mathrm{V}_{2} \mathrm{O}_{5}$ promoted sample. After we have subtracted the X-ray satellites of the $\mathrm{O} 1 \mathrm{~s}$ peak and compared the results obtained on the sample as prepared with the reduced catalyst we have found some oxidation state decrease of the vanadium. In the case of the sample as prepared we have detected $\mathrm{V} 2 \mathrm{p}_{3 / 2}$ binding energy at $517.7 \mathrm{eV}$ which corresponds to $\mathrm{V}^{5+}$ whose value shifts to $516.4 \mathrm{eV}$ after reduction that can be assigned to $\mathrm{V}^{4+}$. Our XPS results is supported by TPR measurements.

The change of oxidation state of $\mathrm{Cu}$ on MWCNT catalyst has been investigated in the synthesis of dimethyl carbonate (DMC) by oxidative carbonylation of methanol. We can clearly establish that copper reduces to its metallic form during reduction because the intensive satellit structure vanishes from the $\mathrm{Cu} 2 \mathrm{p}$ spectrum. At the beginning of the reaction we observ the oxidation of copper mostly in $\mathrm{Cu}^{+}$state, with some amount of $\mathrm{Cu}^{2+}$ also present on the surface that can be concluded from the reappearing satellit bands and from the value of the Auger parameter. We assume that the DMC formation rate depends on the surface concentration of $\mathrm{Cu}^{+}$. 


\section{Irodalomjegyzék}

[1] Q. Fu, T. Wagner, Surf. Sci. Rep. 62, 431 (2007)

[2] F. Solymosi, Importance of the electric properties of supports in the carrier effect, Catal. Rev. Sci. Eng. 1, 233 (1967)

[3] G.M. Schwab, Electronics of supported catalysts, Adv. Catal. 27, 1 (1978)

[4] M. Che, C.O. Bennett, The influence of particle-size on the catalytic properties of supported metals, Adv. Catal. 36, 55 (1989)

[5] S.J. Tauster, S.C. Fung, R.L. Garten, Strong metal-support interactions. Group 8 noble metals supported on $\mathrm{TiO}_{2}$, J. Am. Chem. Soc. 100, 170 (1978)

[6] A.T. Bell, The impact of nanoscience on heterogeneous catalysis, Science 299, 1688 (2003)

[7] A. Berkó, I. Ulrych, K.C. Prince, Encapsulation of Rh nanoparticles supported on $\mathrm{TiO}_{2}(110)$ (1x1) surface: XPS and STM studies, J. Phys. Chem. B 102, 3379 (1998)

[8] G.L. Haller, D.E. Resasco, Metal-support interaction: Group VIII metals and reducible oxides, Adv. Catal. 36, 173 (1989)

[9] O. Dulub, W. Hebenstreit, U. Diebold, Imaging cluster surfaces with atomic resolution: The strong metal-support interaction state of Pt supported on $\mathrm{TiO}_{2}$ (110), Phys. Rev. Lett. 84, 3646 (2000)

[10] H.R. Sadeghi, V.E. Henrich, Rh on $\mathrm{TiO}_{2}$ : Model catalyst studies of the strong metal-support interaction, Appl. Surf. Sci. 19, 330 (1984)

[11] F. Pesty, H.P. Steinrück, T.E. Madey, Thermal stability of Pt films on $\mathrm{TiO}_{2}(110)$ : Evidence for encapsulation, Surf. Sci. 339, 83 (1995)

[12] R.A. Bennett, P. Stone, M. Bowker, Pd nanoparticle enhanced reoxidation of nonstoichiometric $\mathrm{TiO}_{2}$ : STM imaging of spillover and a new form of SMSI, Catal. Lett. 59, 99 (1999) 
[13] R.A. Bennett, C.L. Pang, N. Perkins, R.D. Smith, P. Morrall, R.I. Kvon, M. Bowker, Surface structures in the SMSI state; Pd on (1x2) reconstructed $\mathrm{TiO}_{2}(110)$, J. Phys. Chem. B 106, 4688 (2002)

[14] Q. Fu, T. Wagner, S. Olliges, H.D. Carstanjen, Metal-oxide interfacial reactions: Encapsulation of Pd on $\mathrm{TiO}_{2}(110)$, J. Phys. Chem. B 109, 944 (2005)

[15] Y. Gao, Y. Liang, S.A. Chambers, Thermal stability and the role of oxygen vacancy defects in strong metal support interaction-Pt on Nb-doped $\mathrm{TiO}_{2}$ (100), Surf. Sci. 365, 638 (1996)

[16] V.E. Henrich and P. A. Cox, The surface science of metal oxides, Cambridge: Cambridge University Press, (1994)

[17] V.E. Henrich, The surfaces of metal oxides, Reports on Progress in Physics 48, 14811541 (1985)

[18] Z. Zhang, S.P. Jeng, and V.E. Henrich, Cation-ligand hybridization for stoichiometric and reduced $\mathrm{TiO}_{2}$ (110) surfaces determined by resonant photoemission, Physical Review B 43, 12004 (1991)

[19] M. Haruta, Catalysis of gold nanoparticles deposited on metal oxides, Cattech 6, 102 (2002)

[20] M. Haruta, Nanoparticulate gold catalysts for low-temperature CO oxidation, Journal of New Materials for Electrochemical Systems 7, 163 (2003)

[21] N. Lopez, J.K. Norskov, Theoretical study of the Au/TiO $O_{2}(110)$ interface, Surf. Sci. 515, 175 (2002)

[22] A. Vijay, G. Mills, H. Metiu, Adsorption of gold on stoichiometric and reduced rutile $\mathrm{TiO}_{2}(110)$ surfaces, J. Chem. Phys. 118, 6536 (2003)

[23] Z. Yang, R.Q. Wu, D.W. Goodman, Structural and electronic properties of Au on $\mathrm{TiO}_{2}(110)$, Phys. Rev. B 61, 14066 (2000)

[24] X. Lai, T.P. St Clair, M. Valden, D.W. Goodman, Scanning tunneling microscopy studies of metal clusters supported on $\mathrm{TiO}_{2}$ (110): Morphology and electronic structure, Prog. Surf. Sci. 59, 25 (1998)

[25] X. Tong, L. Benz, P. Kemper, H. Metiu, M.T. Bowers, S.K. Buratto, Intact size-selected Aun clusters on a $\mathrm{TiO}_{2}(110)-(1 x 1)$ surface at room temperature, J. Am. Chem. Soc. 127, 13516 (2005)

[26] Z.G. Szabó, D. Kalló, Contact catalysis, Akadémiai Kiadó, Budapest (1976)

[27] U. Diebold, The surface science of titanium dioxide, Surf. Sci. Rep. 48, 53 (2003) 
[28] P. Krüger, S. Bourgeois, B. Domenichini, H. Magnan, D. Chandesris, P. Le Fèvre, A. Flank, J. Jupille, L. Floreano, A. Cossaro, A. Verdini, and A. Morgante, Defect states at the $\mathrm{TiO}_{2}(110)$ surface probed by resonant photoelectron diffraction, Physical Review Letters 100, 055501 (2008)

[29] V.E. Henrich, G. Dresselhaus, H.J. Zeiger, Observation of two-dimensional phases associated with defect states on the surface of $\mathrm{TiO}_{2}$, Phys. Rev. Lett. 36, 1335 (1976)

[30] U. Diebold, J. Lehman, T. Mahmoud, M. Kuhn, G. Leonardelli, W. Hebenstreit, M. Schmid, P. Varga, Intrinsic defects on a $\mathrm{TiO}_{2}(110)-(1 x 1)$ surface and their reaction with oxygen: A scanning tunneling microscopy study, Surf. Sci. 411, 137 (1998)

[31] M.A. Henderson, The interaction of water with solid surfaces:Fundamental aspects revisited, Surf. Sci. Rep. 46, 1 (2002)

[32] S. Wendt, J. Matthiesen, R. Schaub, E.K. Vestergaard, E. Lægsgaard, F. Besenbacher, B. Hammer, Formation and splitting of paired hydroxyl groups on reduced $\mathrm{TiO}_{2}(110)$, Phys. Rev. Lett. 96, 066107 (2006)

[33] Z. Zhang, O. Bondarchuk, B.D. Kay, J.M. White, Z. Dohnalek, Imaging water dissociation on $\mathrm{TiO}_{2}$ (110): Evidence for inequivalent geminate OH groups, J. Phys. Chem. B 110, 21840 (2006)

[34] P.W. Murray, N.G. Condon, G. Thornton, $\mathrm{Na}$ adsorption sites on $\mathrm{TiO}_{2}(110)-1 \times 2$ and its $2 \times 2$ superlattice, Surf. Sci. 323, 281 (1995)

[35] C.L. Pang, C.A. Muryn, A.P. Woodhead, H. Raza, S.A. Haycock, V. Dhanak, G. Thornton, Low-coverage condensation of $\mathrm{K}$ on $\mathrm{TiO}_{2}$ (110) 1x1, Surf. Sci. 583, 147 (2005)

[36] O. Bikondoa, C.L. Pang, C.A. Muryn, B.G. Daniels, S. Ferrero, E. Michelangeli, G. Thornton, Ordered overlayers of Ca on $\mathrm{TiO}_{2}$ (110)-1xl, J. Phys. Chem. B 108, 16768 (2004)

[37] K. Luo, T.P.S. Clair, X. Lai, D.W. Goodman, Silver growth on $\mathrm{TiO}_{2}(110)(1 x 1)$ and (1x2), J. Phys. Chem. B 104, 3050 (2000)

[38] D.A. Chen, M.C. Bartelt, R.Q. Hwang, K.F. McCarty, Self-limiting growth of copper islands on $\mathrm{TiO}_{2}(110)-(1 x 1)$, Surf. Sci. 450, 78 (2000)

[39] M. Valden, X. Lai, D.W. Goodman, Onset of catalytic activity of gold clusters on titania with the appearance of nonmetallic properties, Science 281, 1647 (1998)

[40] A.K. Santra, F. Yang, D.W. Goodman, The growth of Ag-Au bimetallic nanoparticles on $\mathrm{TiO}_{2}$ (110), Surf. Sci. 548, 324 (2004) 
[41] T. Minato, T. Susaki, S. Shiraki, H.S. Kato, M. Kawai, K. Aika, Investigation of the electronic interaction between $\mathrm{TiO}_{2}(110)$ surfaces and Au clusters by PES and STM, Surf. Sci. 1012, 566 (2004)

[42] M.J.J. Jak, C. Konstapel, A. van Kreuningen, J. Chrost, J. Verhoeven, J.W.M. Frenken, The influence of substrate defects on the growth rate of palladium nanoparticles on a $\mathrm{TiO}_{2}(110)$ surface, Surf. Sci. 474, 28 (2001)

[43] K. Fukui, H. Onishi, Y. Iwasawa, Atom-resolved image of the $\mathrm{TiO}_{2}(110)$ surface by noncontact atomic force microscopy, Phys. Rev. Lett. 79, 4202 (1997)

[44] X. Tong, L. Benz, A. Kolmakov, S. Chretien, H. Metiu, S.K. Buratto, The nucleation sites of Ag clusters grown by vapor deposition on a $\mathrm{TiO}_{2}(110)$-1xl surface, Surf. Sci. 575, 60 (2005)

[45] E. Wahlström, N. Lopez, R. Schaub, P. Thostrup, A. Rønnau, C. Africh, E. Lægsgaard, J.K. Nørskov, F. Besenbacher, Bonding of gold nanoclusters to oxygen vacancies on rutile $\mathrm{TiO}_{2}$ (110), Phys. Rev. Lett. 90, 026101 (2003)

[46] A.S. Wörz, U. Heiz, F. Cinquini, G. Pacchioni, Charging of Au atoms on $\mathrm{TiO}_{2}$ thin films from CO vibrational spectroscopy and DFT calculations, J. Phys. Chem. B 10, 18418 (2005)

[47] S. Wendt, R. Schaub, J. Matthiesen, E.K. Vestergaard, E. Wahlström, M.D. Rasmussen, P. Thostrup, L.M.Molina, E. Lægsgaard, I. Stensgaard, B. Hammer, F. Besenbacher, Oxygen vacancies on $\mathrm{TiO}_{2}(110)$ and their interaction with $\mathrm{H}_{2} \mathrm{O}$ and $\mathrm{O}_{2}$ : A combined high-resolution STM and DFT study, Surf. Sci. 598, 226 (2005)

[48] D. Matthey, J.G. Wang, S. Wendt, J. Matthiesen, R. Schaub, E. Lægsgaard, B. Hammer, F. Besenbacher, Enhanced bonding of gold nanoparticles on oxidized $\mathrm{TiO}_{2}(110)$, Science 315, $1692(2007)$

[49] C.T. Campbell, Ultrathin metal films and particles on oxide surfaces: Structural, electronic and chemisorptive properties, Surf. Sci. Rep. 27, 1 (1997)

[50] L.S. Dake, R.J. Lad, Electronic and chemical interactions at aluminium/TiO ${ }_{2}(110)$ interfaces, Surf. Sci. 289, 297 (1993)

[51] J. Wang, J. Biener, R.J. Madix, Temperature effects on vanadium overlayers on the $\mathrm{TiO}_{2}(110)$ (1x2) surface, J. Phys. Chem. B 104, 3286 (2000)

[52] J.M. Pan, U. Diebold, L.Z. Zhang, T.E. Madey, Ultrathin reactive metal films on $\mathrm{TiO}_{2}(110)$ : Growth, interfacial interaction and electronic structure of chromium films, Surf. Sci. 295, 411 (1993)

[53] V. Blondeau-Patissier, B. Domenichini, A. Steinbrunn, S. Bourgeois, $\operatorname{MoO}_{x}(x<2)$ ultrathin film growth from reactions between metallic molybdenum and $\mathrm{TiO}_{2}$ surfaces, Appl. Surf. Sci. 674, 175 (2001) 
[54] H. Onishi, Y. Iwasawa, Dynamic visualization of a metal-oxidesurface/gas-phase reaction: Time-resolved observation by scanning tunneling microscopy at $800 \mathrm{~K}$, Phys. Rev. Lett. 76, 791 (1996)

[55] R.A. Bennett, P. Stone, N.J. Price, M. Bowker, Two (1x2) reconstructions of TiO (110): Surface rearrangement and reactivity studied using elevated temperature scanning tunneling microscopy, Phys. Rev. Lett. 82, 3831 (1999)

[56] M.A. Henderson, Mechanism for the bulk-assisted reoxidation of ion sputtered $\mathrm{TiO}_{2}$ surfaces: Diffusion of oxygen to the surface or titanium to the bulk?, Surf. Sci. 343, 1156 (1995)

[57] M.A. Henderson, A surface perspective on self-diffusion in rutile $\mathrm{TiO}_{2}$, Surf. Sci. 419, 174 (1999)

[58] M. Li, W. Hebenstreit, U. Diebold, Oxygen-induced restructuring of the rutile $\mathrm{TiO}_{2}(110)$ (1x1) surface, Surf. Sci. 414, 951 (1998)

[59] U. Diebold, J.M. Pan, T.E. Madey, Ultrathin metal film growth on $\mathrm{TiO}_{2}(110)$ : An overview, Surf. Sci. 845, 331 (1995)

[60] R.J. Lad, Interactions at metal/oxide and oxide/oxide interfaces studied by ultrathin film growth on single-crystal oxide substrate, Surf. Rev. Lett. 2, 109 (1995)

[61] T. Wagner, J. Marien, G. Duscher, $\mathrm{Cu}, \mathrm{Nb}$ and $\mathrm{V}$ on (110) $\mathrm{TiO}_{2}$ (rutile): Epitaxy and chemical reactions, Thin Solid Films 419, 398 (2001)

[62] J. Marien, T. Wagner, G. Duscher, A. Koch, M. Rühle, $\mathrm{Nb}$ on (110) $\mathrm{TiO}_{2}$ (rutile): Growth, structure, and chemical composition of the interface, Surf. Sci. 446, 219 (2000)

[63] S. Iijima, Helical microtubules of graphitic carbon, Nature 354, 56 (1991)

[64] G.T. Chandrappa, N. Steunou, S. Cassaignon, C. Bauvais, J. Livage, Hydrothermal synthesis of vanadium oxide nanotubes from $\mathrm{V}_{2} \mathrm{O}_{5}$ gels, Catal. Today 78, 85 (2003)

[65] X. Xiang, C. Cao, Y. Guo and H. S. Zhu, A simple method to synthesize gallium oxide nanosheets and nanobelts, Chem. Phys. Lett. 378, 660 (2003)

[66] M. Law, L. E. Greene and A. Radenovic, $\mathrm{ZnO}-\mathrm{Al}_{2} \mathrm{O}_{3}$ and $\mathrm{ZnO}-\mathrm{TiO}_{2}$ core-shell nanowire dyesensitized solar cells, J. Phys. Chem. B 110, 22652 (2006)

[67] C. L. Yan and D. Xue, Conversion of ZnO nanorod arrays into $\mathrm{ZnO} / \mathrm{ZnS}$ nanoeable and $\mathrm{ZnS}$ nanotube arrays via an in situ chemistry strategy, J. Phys. Chem. B 110, 25850 (2006)

[68] E. Reck and S. Seymour, The effect of $\mathrm{TiO}_{2}$ pigment on the performance of paratoluene sulphonic acid catalysed paint systems, Macromol. Symp. 187, 707 (2002) 
[69] M. Zlamal, J.M. Macak, P. Schmuki, J. Krysa Electrochemically assisted photocatalysis on self-organized $\mathrm{TiO}_{2}$ nanotubes, Electrochem. Comm. 9, 2822 (2007)

[70] G.K. Mor, O.K. Varghese, M. Paulose, K. Shankar, C.A. Grimes, A review on highly ordered, vertically oriented $\mathrm{TiO}_{2}$ nanotube arrays: fabrication, material properties, and solar energy applications, Sol. Energy Mater. Sol. Cells 90, 2011 (2006)

[71] I.A. Al-Homoudi, J.S. Thakur, R. Naik, G.W. Auner, G. Newaz, Anatase $\mathrm{TiO}_{2}$ films based CO gas sensor: film thickness, substrate and temperature effects, Appl. Surf. Sci. 253, 8607 (2007)

[72] T. Kasuga, M. Hiramatsu, A. Hoson, T. Sekino and K. Niihara, Formation of titanium oxide nanotube, Langmuir 14, 3160 (1998)

[73] E. Horváth, Á. Kukovecz, Z. Kónya, I. Kiricsi, Hydrothermal conversion of self-assembled titanate nanotubes into nanowires in a revolving autoclave, Chem. Mater. 19, 927 (2007)

[74] Q. Chen, W. Zhou, G. Du and L.M. Peng, Trititanate nanotubes made via a single alkali treatment, Adv. Mater. 14, 1208 (2002)

[75] X.M. Sun, Y.D. Li, Synthesis and characterization of ion-exchangeable titanate nanotubes, Chem.-Eur. J. 9, 2229 (2003)

[76] J. Yang, Z. Jin, X. Wang, W. Li, J. Zhang, S. Zhang, X. Guo, J. Zhang, Study on composition, structure and formation process of nanotube $\mathrm{Na}_{2} \mathrm{Ti}_{2} \mathrm{O}_{4}(\mathrm{OH})$, Dalton Trans. 20, 3898 (2003)

[77] A. Nakahira, W. Kato, M. Tamai, T. Isshiki, K. Nishio, H. Aritani, Synthesis of nanotube from a layered $\mathrm{H}_{2} \mathrm{Ti}_{4} \mathrm{O}_{9} \cdot 7 \mathrm{H}_{2} \mathrm{O}$ in a hydrothermal treatment using various titania sources, J. Mater. Sci. 39, 4239 (2004)

[78] A.R. Armstrong, G. Armstrong, J. Canales and P.G. Bruce, $\mathrm{TiO}_{2}-\mathrm{B}$ nanowires, Angew. Chem. Int. Ed., 43, 2286 (2004)

[79] D.A. Wang, F. Zhou, C.W. Wang and W. Liu, Synthesis and characterization of silver nanoparticle loaded mesoporous $\mathrm{TiO}_{2}$ nanobelts, Microporous Mesoporous Mater. 116, 658 (2008)

[80] A. Riss, M.J. Elser, J. Bernardi, O. Diwald, Stability and photoelectronic properties of layered titanate nanostructures, J. Am. Chem. Soc. 131, 6198 (2009)

[81] P. Umek, P. Cevc, A. Jesih, A. Gloter, C.P. Ewels, D. Arcon, Impact of structure and morphology on gas adsorption of titanate-based nanotubes and nanoribbons, Chem. Mater. 17, 5945 (2005)

[82] Y.B. Mao, S.S. Wong, Size- and shape-dependent transformation of nanosized titanate into analogous anatase Titania nanostructures, J. Am. Chem. Soc. 128, 8217 (2006) 
[83] J. N. Nian, H. Teng, Hydrothermal synthesis of single-crystalline anatase $\mathrm{TiO}_{2}$ nanorods with nanotubes as the precursor, J. Phys. Chem. B 110, 4193 (2006)

[84] D.V. Bavykin, J.M. Friedrich, A.A. Lapkin, F.C. Walsh, Stability of aqueous suspensions of titanate nanotubes, Chem. Mater. 18, 1124 (2006)

[85] D.V. Bavykin, V.N. Parmon, A.A. Lapkin, F.C. Walsh, The effect of hydrothermal conditions on the mesoporous structure of $\mathrm{TiO}_{2}$ nanotubes, J. Mater. Chem. 14, 3370 (2004)

[86] E. Morgado Jr, P.M. Jardim, B.A. Marinkovic, F.C. Rizzo, M.A.S. de Abreu, J.L. Zotin, A.S. Araújo, Multistep structural transition of hydrogen trititanate nanotubes into $\mathrm{TiO}_{2}-\mathrm{B}$ nanotubes: a comparison study between nanostructured and bulk materials, Nanotechnol. 18, 495710 (2007)

[87] A. Thorne, A. Kruth, D. Tunstall, J.T.S. Irvine, W. Zhou, Formation, structure, and stability of titanate nanotubes and their proton conductivity, J. Phys. Chem. B 109, 5439 (2005)

[88] S. Pavasupree, Y. Suzuki, S. Yoshikawa, R. Kawahata, Synthesis of titanate, $\mathrm{TiO}_{2}(B)$ and anatase $\mathrm{TiO}_{2}$ nanofibers from natural rutile sand, J. Solid State Chem. 178, 3110 (2005)

[89] J. Suetake, A.Y. Nosaka, K. Hodouchi, H. Matsubara, Y. Nosaka, Characteristics of titanate nanotube and the states of the confined sodium ions, J. Phys. Chem. C 112, 18474 (2008)

[90] M. Qamar, C.R. Yoon, H.J. Oh, D.H. Kim, J.H. Jho, K.S. Lee, W.J. Lee, H.G. Lee, S.J. Kim, Effect of post treatments on the structure and thermal stability of titanate nanotubes, Nanotechnology 17, 5922 (2006)

[91] Y.V. Koleńko, K.A. Kovnir, A.I. Gavrilov, A.V. Garshev, Hydrothermal synthesis and characterization of nanorods of various titanates and titanium dioxide, J. Phys. Chem. B 110, 4030 (2006)

[92] R. Ma, T. Sasaki, Y. Bando, Alkali metal cation intercalation properties of titanate nanotubes, Chem. Commun. 7, 948 (2005)

[93] J. Kim, J. Cho, Spinel $\mathrm{Li}_{4} \mathrm{Ti}_{5} \mathrm{O}_{12}$ nanowires for high-rate Li-ion intercalation electrode, Electrochem. Solid-State Lett. 10, A81 (2007)

[94] H.Y. Zhang, T.H. Ji, L.L. Li, X.Y. Qi, Y.F. Liu, J.W. Cai, Preparation and characterization of room-temperature ferromagnetic Ni-doped $\mathrm{TiO}_{2}$ nanobelts, Acta Phys.-Chim. Sin. 24, 607 (2008)

[95] D.V. Bavykin, S.N. Gordeev, A.V. Moskalenko, A.A. Lapkin, F.C. Walsh, Apparent twodimensional behavior of $\mathrm{TiO}_{2}$ nanotubes revealed by light absorption and luminescence, $\mathrm{J}$. Phys. Chem. B 109, 8565 (2005) 
[96] N. Sakai, Y. Ebina, K. Takada, T. Sasaki, Electronic band structure of titania semiconductor nanosheets revealed by electrochemical and photoelectrochemical studies, J. Am. Chem. Soc. 126, 5851 (2004)

[97] C.C. Tsai, H. Teng, Nanotube formation from a sodium titanate powder via low-temperature acid treatment, Langmuir 24, 3434 (2008)

[98] M.A. Khan, H.T. Jung, O. Yang, Synthesis and characterization of ultrahigh crystalline $\mathrm{TiO}_{2}$ nanotubes, J. Phys. Chem. B 110, 6626 (2006)

[99] J.S. Jang, S.H. Choi, D.H. Kim, J.W. Jang, K.S. Lee, J.S. Lee, Enhanced photocatalytic hydrogen production from water-methanol solution by nickel intercalated into titanate nanotube, J. Phys. Chem. C 113, 8990 (2009)

[100] T. Godfroid, R. Gouttebaron, J.P. Dauchot, P.H. Leclère, R. Lazzaroni, M. Hecq, Growth of ultrathin Ti films deposited on $\mathrm{SnO}_{2}$ by magnetron sputtering, Thin Solid Films 437, 57 (2003)

[101] J. Pouilleau, D. Devilliers, F. Garrido, S. Durand-Vidal, E. Mahé, Structure and composition of passive titanium oxide films, Mater. Sci. Eng. B 47, 253 (1997)

[102] E. McCafferty, J.P. Wightman, An X-ray photoelectron spectroscopy sputter profile study of the native air-formed oxide film on titanium, Appl. Surf. Sci. 143, 92 (1999)

[103] A.R. González-Elipe, G. Munuera, J.P. Espinos, J.M. Sanz, Compositional changes induced by $3.5 \mathrm{keV} \mathrm{Ar}^{+}$ion bombardment in Ni-Ti oxide systems: A comparative study, Surf. Sci. 220 , 368 (1989)

[104] M.C. Asensio, M. Kerkar, D.P. Woodruff, A.V. de Carvalho, A. Fermindez, A.R. GonzálezElipe, M. Fernández-Garcia, J.C. Conesa, The growth of thin Ti and TiO $O_{x}$ films on Pt(111): Morphology and oxidation states, Surf. Sci. 273, 31 (1992)

[105] C.N. Sayers, N.R. Armstrong, $X$-ray photoelectron spectroscopy of $\mathrm{TiO}_{2}$ and other titanate electrodes and various standard titanium oxide materials: Surface compositional changes of the $\mathrm{TiO}_{2}$ electrode during photoelectrolysis, Surf. Sei. 77, 301 (1978)

[106] H. Idriss, K.S. Kim, M.A. Barteau, Surface-dependent pathways for formaldehyde oxidation and reduction on $\mathrm{TiO}_{2}(001)$, Surf. Sci. 262, 113 (1992)

[107] J.T. Mayer, U. Diebold, T.E. Madey, E. Garfunkel, Titanium and reduced titania overlayers on titanium dioxide(110), J. Electr. Spectrosc. Rel. Phen. 73, 1 (1995)

[108] D.J. Dwyer, S.D. Cameron, J. Gland, Surface modification of platinum by titanium dioxide overlayers: A case of simple site blocking, Surf. Sci. 159, 430 (1985) 
[109] H. Perron, J. Vandenborre, C. Domain, R. Drot, J. Roques, E. Simoni, J.-J. Ehrhardt, H. Catalette, Combined investigation of water sorption on $\mathrm{TiO}_{2}$ rutile (110) single crystal face: XPS vs. periodic DFT, Surf. Sci. 601, 518 (2007)

[110] M.G. Mason, Electronic structure of supported small metal clusters, Phys. Rev. B 27, 749 (1983)

[111] A. Kawabata, R. Kubo, Electronic properties of fine metallic particles. II Plasma resonance absorption, J. Phys. Soc. Jpn. 21, 1765 (1966)

[112] M.E. Lin, R.P. Andres, R. Reifenberger, Observation of the discrete electron energy states of an individual nanometer- size supported gold cluster, Phys. Rev. Lett. 67, 477 (1991)

[113] L. Oberli, R. Monot, H.J. Mathieu, D. Landolt, J. Buffet, Auger and X-ray photoelectron spectroscopy of small Au particles, Surf. Sci. 106, 301 (1981)

[114] M.K. Bahl, S.C. Tsai, Y.W. Chung, Auger and photoemission investigations of the platinum$\mathrm{SrTiO}_{3}$ (100) interface: Relaxation and chemical-shift effects, Phys. Rev. B 21, 1344 (1980)

[115] Y. Wu, E. Garfunkel, T.E. Madey, Initial stages of $\mathrm{Cu}$ growth on ordered $\mathrm{Al}_{2} \mathrm{O}_{3}$ ultrathin films, J. Vac. Sci. Technol. A 14, 1662 (1996)

[116] I. Jirka, An ESCA study of copper clusters on carbon, Surf. Sci. 232, 307 (1990)

[117] P. Ascarelli, M. Cini, G. Missoni, N. Nistico, X.P.S. line broadening in small metal particles, J. Phys. (Paris) Colloq. 38, 125 (1977)

[118] S. Lee, C. Fan, T. Wu, S.L. Anderson, Agglomeration, support effects, and CO adsorption on $\mathrm{Au}_{\mathrm{TiO}}$ (110) prepared by ion beam deposition, Surf. Sci. 578, 5 (2005)

[119] G. Blyholder, Molecular orbital view of chemisorbed carbon monoxid, J. Phys. Chem. 68, 2772 (1964)

[120] D.C. Meier, V. Bukhtiyarov, D.W. Goodman, CO adsorption on Au(110)-[1x2]: an IRAS investigation, J. Phys. Chem. B 107, 12668 (2003)

[121] Á. Kukovecz, M. Hodos, E. Horváth, Gy. Radnóczi, Z. Kónya, I. Kiricsi, Oriented crystal growth model explains the formation of titania nanotubes, J. Phys. Chem. B 109, 17781 (2005)

[122] G. Pótári, D. Madarász, L. Nagy, B. László, A. Sápi, A. Oszkó, Á. Kukovecz, A. Erdőhelyi, Z. Kónya, J. Kiss, Rh-induced support transformation phenomena in titanate nanowire and nanotube catalysts, Langmuir 29, 3061 (2013)

[123] J. Kiss, A. Oszkó, G. Pótári, A. Erdóhely, Role of the nature of support on the structure of Au-Rh bimetallic nanoparticles, Vacuum 86, 594 (2012) 
[124] F. Solymosi, M. Pásztor, An infrared study of the influence of CO chemisorption on the topology of supported rhodium, J. Phys. Chem. 89, 4789 (1985)

[125] L. Óvari, A. Berkó, N. Balázs, Zs. Majzik, J. Kiss, Formation of Rh-Au core-shell nanoparticles on $\mathrm{TiO}_{2}$ (110) surface studied by STM and LEIS , Langmuir 26, 2167 (2010)

[126] Á. Kukovecz, G. Pótári, A. Oszkó, Z. Kónya, A. Erdőhelyi, J. Kiss, Probing the interaction of $\mathrm{Au}, \mathrm{Rh}$ and bimetallic $\mathrm{Au}$-Rh clusters with the $\mathrm{TiO}_{2}$ nanowire and nanotube support, Surf. Sci. 605, 1048 (2011)

[127] M. Tóth, J. Kiss, A. Oszkó, G. Pótári, B. László, A. Erdőhelyi, Hydrogenation of carbon dioxide on Au-Rh bimetallic clusters supported on titanate nanotubes, nanowires and $\mathrm{TiO}_{2}$, Top. Catal. 55, 747 (2012)

[128] D. Madarász, G. Pótári, A. Sápi, B. László, C. Csudai, A. Oszkó, A. Kukovecz, A. Erdőhelyi, Z. Kónya, J. Kiss, Metal loading determines the stabilization pathway for $\mathrm{Co}^{2+}$ in titanate nanowires: ion exchanges vs. cluster formation, Phys. Chem. Chem. Phys. 15, 15917 (2013)

[129] A. Sasahara, C.L. Pang, H. Onishi, Local work function of Pt clusters vacuum-deposited on a $\mathrm{TiO}_{2}$ surface, J. Phys. Chem. B 110, 17584 (2006)

[130] M.C.J. Bradford, M.A. Vannice, $\mathrm{CO}_{2}$ reforming of $\mathrm{CH}_{4}$, Catal. Rev., 41, 1 (1999)

[131] F. Solymosi, Gy. Kutsán, A. Erdôhelyi, Catalytic reaction of $\mathrm{CH}_{4}$ with $\mathrm{CO}_{2}$ over aluminasupported Pt metals, Catal. Lett. 11, 149 (1991)

[132] A. Erdôhelyi, J. Cserényi, F. Solymosi, Activation of $\mathrm{CH}_{4}$ and its reaction with $\mathrm{CO}_{2}$ over supported Rh catalysts, J. Catal. 141, 287 (1993)

[133] J. Wei, E. Iglesia, Structural requirements and reaction pathways in methane activation and chemical conversion catalyzed by rhodium, J. Catal. 225, 116 (2004)

[134] A. Erdőhelyi, K. Fodor, T. Szailer, Effect of $\mathrm{H}_{2} \mathrm{~S}$ on the reaction of methane with carbon dioxide over supported Rh catalysts, Appl. Catal. B: Environ. 53, 153 (2004)

[135] J. Nakamura, K. Aikawa, K. Sato, T.T. Uchijima, Role of support in reforming of $\mathrm{CH}_{4}$ with $\mathrm{CO}_{2}$ over Rh catalysts, Catal. Lett. 25, 265 (1994)

[136] J.H. Bitter, K. Seshan, J.A. Lercher, Mono and bifunctional pathways of $\mathrm{CO}_{2} / \mathrm{CH}_{4}$ reforming over platinum and rhodium based catalysts, J. Catal. 176, 93 (1998)

[137] M. Sigl, M.C.J. Bradford, H. Knözinger, M.A. Vannice, $\mathrm{CO}_{2}$ reforming of methane over vanadia-promoted $\mathrm{Rh} / \mathrm{SiO}_{2}$ catalysts, Top. Catal. 8, 211 (1999)

[138] I. Sarusi, K. Fodor, K. Baán, A. Oszkó, G. Pótári, A. Erdôhelyi, $\mathrm{CO}_{2}$ reforming of $\mathrm{CH}_{4}$ on doped $\mathrm{Rh}_{\mathrm{A}} \mathrm{I}_{2} \mathrm{O}_{3}$ catalysts, Cat. Tod. 171, 132 (2011) 
[139] M.C.J. Bradford, M.A. Vannice, The role of metal-support interactions in $\mathrm{CO}_{2}$ reforming of $\mathrm{CH}_{4}$, Catal. Today 50, 87 (1999)

[140] S.M. Stagg-Willians, F.B. Noronha, E.G. Fendley, D.E. Resasco, $\mathrm{CO}_{2}$ reforming of $\mathrm{CH}_{4}$ over $\mathrm{Pt} / \mathrm{ZrO} \mathrm{O}_{2}$ catalysts promoted with La and Ce oxides, J. Catal. 194, 240 (2000) 


\section{Köszönetnyilvánítás}

Mindenek előtt témavezetőmnek, Dr. Erdőhelyi Andrásnak szeretném hálámat kifejezni, aki lehetôvé tette számomra, hogy kutatócsoportjában végezhessem doktori munkámat. Ugyancsak köszönettel tartozom Dr. Kiss Jánosnak, akivel közösen végzett munkáinkat legszebb emlékeim között tartok számon. Köszönet illeti Moldován Gergelyt is, akire mindig számítani lehetett, ha a készülék javításához segítségre volt szükség. Továbbá hálás vagyok az Alkalmazott és Környezeti Kémiai Tanszék és a Fizikai Kémiai és Anyagtudományi Tanszék azon munkatársainak is, akikkel együttmúködve végeztem munkámat.

A disszertáció megírása a TÁMOP 4.2.4.A/2-11-1-2012-0001 azonosító számú Nemzeti Kiválóság Program - Hazai hallgatói, illetve kutatói személyi támogatást biztosító rendszer kidolgozása és múködtetése országos program címú kiemelt projekt által nyújtott személyi támogatással valósult meg, amit ezúton is hálásan köszönök. 